\title{
NEW HORIZONS \\ IN BUSINESS AND \\ MANAGEMENT \\ STUDIES
}

CONFERENCE PROCEEDINGS

SZÉCHENYI 2020

European Union

European Social

Fund

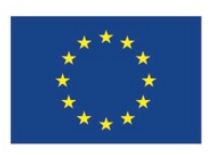

HUNGARIAN

GOVERNMENT

INVESTING IN YOUR FUTURE 


\section{New Horizons in Business and Management Studies}

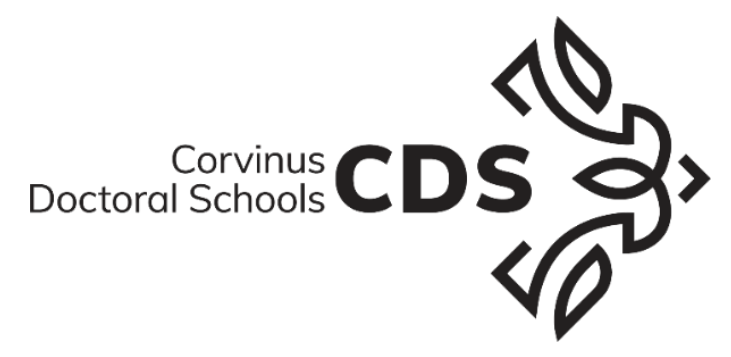

Conference of the Doctoral School of Business and Management at the Corvinus University of Budapest

\section{CONFERENCE PROCEEDINGS}

Edited by

Máté Baksa, Nóra Fazekas, and Vanda Harmat

2021

Budapest 


\section{New Horizons in Business and Management Studies}

Online scientific conference, January 7, 2021

Organized by the Doctoral School of Business and Management in cooperation with the Doctoral Student Council of the Corvinus University of Budapest.

\section{Scientific Committee}

Prof. Dr. Gábor Michalkó (chairman)

Prof. Dr. Ágnes Zsóka (member)

Prof. Dr. Henriett Primecz (session chair)

Dr. György Drótos (session chair)

Dr. Dávid Taródy (session chair)

\section{Organizing Committee}

Máté Baksa

Nóra Fazekas

Vanda Harmat

\section{Reviewers}

Dr. Márta Aranyossy

Dr. Imre Branyiczki

Dr. Nikolett Deutsch

Dr. György Drótos

Dr. Tamás Kristóf

Dr. Róbert Marciniak

Prof. Dr. Tamás Mészáros

Dr. Judit Nagy

Dr. Éva Pintér

Dr. Éva Révész

Dr. Szabolcs Sz. Sebrek

Dr. Roland Zs. Szabó

Prof. Dr. Sándor Takács

ISBN: 978-963-503-867-1 (online)

DOI: $10.14267 / 978-963-503-867-1$

Published by the Corvinus University of Budapest

Budapest, 2021

The present publication is the outcome of the project "From Talent to Young Researcher project aimed at activities supporting the research career model in higher education," identifier EFOP-3.6.3-VEKOP16-2017-00007 co-supported by the European Union, Hungary, and the European Social Fund. 


\title{
Table of Contents
}

\section{Digital Transformation Session}

\author{
Ronnen Avny \\ THE INFLUENCE OF THE FOURTH INDUSTRIAL REVOLUTION ON THE
}

ENTREPRENEUR LEADERSHIP ATTRIBUTES

Kitti Dióssy

ARE THE ROBOTS GOING TO TAKE OUR JOBS? THIS IS HOW AMERICAN AND HUNGARIAN ECONOMISTS OF GENERATIONS Y AND Z CONCEIVE THE IMPACT

OF ARTIFICIAL INTELLIGENCE.

Nóra Fazekas

LEARNING ORGANIZATIONS AND ORGANIZATIONAL DIGITAL COMPETENCIES

IN THE FIELD OF PUBLIC EDUCATION.

Anna Freund

THE SIGNS OF DIGITALIZATION ON FOOD SAFETY ISSUES: A LITERATURE REVIEW FOCUSING ON TRACEABILITY

Diána Nagy

POSSIBILITIES OF DIGITALIZATION AND SERVICE DESIGN IN THE

DEVELOPMENT OF PATIENT ADHERENCE .49

Tibor Tóth

THE EFFECTS OF COVID-19 ON THE DIGITAL TRANSFORMATION OF THE HUNGARIAN BANKING SECTOR .56

\section{Organization and Management Theory Session}

\section{Máté Baksa}

A RELATIONAL FOUNDATION OF KNOWLEDGE PRODUCTION: ADVICESEEKING IN KNOWLEDGE-BASED ORGANIZATIONS.

Sára Forgács-Fábián

RETENTION OF MILLENNIALS IN THE VOLUNTARY SECTOR: HOW CAN ORGANIZATIONS NOT ONLY ENGAGE BUT ALSO RETAIN THIS EMERGING GENERATION?

Rita Tóth

THIN ICE: TEASING PLAY AS A NETWORK-FORMING FORCE IN ORGANIZATIONS 


\section{Strategic Management Session}

\section{Anara Bekmukhambetova}

COMPARATIVE ANALYSIS OF CHANGE MANAGEMENT MODELS BASED ON AN EXPLORATORY LITERATURE REVIEW

Claudia Da Silva Jordão

THE IMPACT OF THE QUALITY OF PUBLIC SPENDING AND INSTITUTIONAL CHANGE ON THE USE OF OIL ROYALTIES: EXPLORING PUBLIC MANAGEMENT RESEARCH

\section{Zoltán Kárpáti}

PROFESSIONALIZATION OF FAMILY FIRMS: STRIKING A BALANCE BETWEEN PERSONAL AND NON-PERSONAL FACTORS

Viktoriia Semenova

ENTRY DYNAMICS OF STARTUP COMPANIES AND THE DRIVERS OF THEIR GROWTH IN THE NASCENT BLOCKCHAIN INDUSTRY

Krisztofer Szabó

NASCENT ENTREPRENEURSHIP: EXPLORATORY RESEARCH BASED ON SYSTEMATIC LITERATURE REVIEW AND TEXT ANALYSIS

\section{Borbála Szedmák}

BUSINESS MODEL INNOVATION AND THE FIRST STEPS OF DIGITALIZATION IN THE CASE OF SYMPHONY ORCHESTRAS 


\title{
The Influence of the Fourth Industrial Revolution on the Entrepreneur Leadership Attributes
}

\author{
RONNEN AVNY* \\ *Corvinus University of Budapest, Doctoral School of Business and Management; \\ ronnen.avny@stud.uni-corvinus.hu
}

DOI: $10.14267 / 978-963-503-867-1 \_01$

\begin{abstract}
Innovation, and especially innovation leadership, is a critical factor in enhancing a firm's success in today's changing markets. This research investigates changes in the entrepreneurial leadership attributes amid the fourth industrial revolution and how these changes relate to the fast pace of technology advancement. As part of the fourth industrial revolution, the barrier to introducing innovative technology has decreased due to the accessibility of high-end commercial capabilities, such as cloud computing, big-data capacities, open-source codes, and more, which reduce their need for in-house development. This research taps into the current academic knowledge gap and aims to understand how leadership traits (or attributes) may help fully exploit this significant revolution's advantages and gain a competitive advantage over rivals. This paper also contributes to the knowledge of innovation study and entrepreneur leadership study. The research utilizes automated techniques of content analysis of published interviews and entrepreneurs' biographies from recent years and the distant past. The results reveal that current entrepreneurs tend to be open-minded while avoiding rejecting innovation from other firms (avoiding "the not invented here" concept) and are willing to share the experience with the adjacent technology eco-system. The main conclusion of the research is that the entrepreneur in the current era should utilize the open innovation eco-system and gather the ingredients for innovation initiatives, and also have the ability to accurately seek the best offthe-shelf solution to use and integrate it while avoiding time- and budget-consuming development procedures.
\end{abstract}

Keywords: innovation, technology, fourth industrial revolution, entrepreneur leadership

Funding: The present publication is the outcome of the project "From Talent to Young Researcher project aimed at activities supporting the research career model in higher education," identifier EFOP-3.6.3-VEKOP-16-2017-00007 co-supported by the European Union, Hungary, and the European Social Fund. 


\section{Introduction}

When looking at the history of humankind, innovation contributes so much to achieving remarkable goals in history. It is one of the vital shaping forces of history, using human creativity to overcome any technological restrains. Innovation appears to be one of the most significant forces supporting economic development. One of the first innovation theorists was the Austrian economist Joseph Schumpeter, and he promoted the concept that innovation is the ultimate source of economic growth and hence is worthy of study (Schumpeter 1934; Fagerberg et al., 2013). Furthermore, innovation is identified as the primary driving force for companies to prosper, grow, and sustain high profitability (Drucker, 1988; Christensen, 1997).

Nowadays, in the emergence of the fourth industrial revolution, the pace of technological advancement has accelerated significantly. As stated by one of the experts in the field, Ray Kurzwell: "We will not experience 100 years of progress in the $21^{\text {st }}$ century - it will be more like 20,000 years of progress [at today's rate]" (Kurzwell, 2004 , p. 1). On the other hand, as the barrier to introducing innovative technology decreases, these phenomena are considered part of the fourth industrial revolution. The adoption rate by the public of evolving technologies has become very quick. Additionally, the ability to learn independently has increased, thanks to the extensive internet knowledgebase. This current situation enables the development of nonconventional innovations by individuals and groups that were not previously involved in innovation and means they can deploy and develop new products and new technologies much more efficiently than we used to years ago (Oxford ourworldindata.org, 2020).

This research aims to link together those three aspects: the current-time innovation paradigm; the leadership attributes of current technological firms; and the significant changes to the technological environment due to the emergence of the fourth industrial revolution. The paper's primary goal is to answer the question of how the entrepreneur adjusts their leadership attributes to cope with the current fast-changing world. Consequently, the primary question needs to be answered: what is the effect of the fourth industrial revolution on entrepreneur leadership attributes? By doing so, the research aims to understand how the changes in the current technological eco-system driven by the fourth industrial revolution impact the entrepreneur and encourage them to alter their leadership attributes to achieve their corporate objectives and succeed with innovation initiatives. This research also creates a preliminary foundation for updating the innovation paradigm related to the fourth industrial revolution, which can be appended to the existing theory of the current open, interactive innovation model. Furthermore, the research creates an opportunity for further research regarding companies' management styles related to the fourth industrial revolution. 
To lay the foundation for this research, the conventional definition of innovation should be called upon. According to Merriam-Webster, innovation is "the introduction of something new" and "a new idea, method, or device - novelty" (Miriam-Webster, 2016), even though, year after year, the definition of innovation is continuously developed (Khayyat \& Lee, 2015). A well-established definition of innovation was written by the Organization for Economic Cooperation and Development (OECD) in its Oslo Manual for Innovation: "An innovation is a new or improved product or process (or a combination thereof) that differs significantly from the unit's previous products or processes, and that has been made available to potential users (product) or brought into use by the unit (process)" (OECD, 2018, p. 20).

The remainder of the paper is organized as follows. Section 2 provides the review of the relevant literature and presents the research background, which is followed by a proposed theoretical framework. Section 3 outlines the methodology and data used to perform the analyses, while Section 4 presents the key findings and the results of each study. The paper concludes with a discussion of the theoretical and managerial implications as well as limitations and avenues for future research.

\section{Theoretical background}

Innovation is a widely spread phenomenon and not restricted only to the technology field; there are wide range of different perspectives toward innovation from different fields. The integration of those perspectives should reveal the essential characteristics of innovation. Most scholars see innovation as a process that responds to a need or opportunity, depends on creative effort, introduces novelty, and, through this, furthers the need for change, and over-all brings the invention to use (Kooij, 2018; Schon, 1967). Another point of view on innovation is by the mechanism which produced the innovation - such as the combination of old and new knowledge, the change-factor the innovation brought, or from the scholar's perspective, as depends on the source and the outcome of the innovation (Kooij, 2013, Torugsa \& Arundel, 2016; Demircioglu \& Audretsch, 2017; Brown \& Osborne, 2012; Ballot et al., 2015; Rajapathirana \& Hui, 2018).

As part of the continually changing world, innovation paradigms should be considered, and mainly their alteration throughout hundreds of years. Hence, the common segregation between the innovation paradigm-eras is to three main dominant models. The first paradigm is the linear-close model, which existed until 1970-1980, and treats innovation as a linear process starting with a scientific effort that produces the invention, then the development of the product, and finally, the marketing of the product. The second paradigm is the open interactive model (or complex system of innovation), which sees innovation as a process involving the whole system, and led to the development of broader innovation theories, such as national innovation systems 
and the Oslo manual. This dominant model existed until the beginning of the 2000s and was founded by the establishment of a dedicated university institute for the academic field of innovation, such as SPRU at the University of Sussex. The third and current leading paradigm is the open interactive model of innovation, reflecting the development of innovation theory towards a fully systemic, dynamic, non-linear process involving a range of interacting agents. This model emphasizes that knowledge flows between actors, expectations about future technology, market and policy developments, political and regulatory risks, and the institutional structures that affect incentives and barriers (Greenacre et al., 2012).

As the second focal point of the research, a distinction must be made between four industrial revolutions during modern history. Each one of them changed the economic world, and not only dramatically. The first revolution in the 18th century was driven mainly by the steam engine's invention, which led to the first large-scale manufactory of textiles, mills, steel, and more (Daemmrich, 2017; Mantoux, 1948). The second revolution occurred at the beginning of the 20th century, as the invention of the internal combustion engine led to the formation of the car industry, the system of large-scale transportation, and the emergence of mass-industry facilities. During this revolution, over 70 percent of American households had electricity, and a wave of new consumer products had entered people's lives (Daemmrich, 2017; Nye, 1992). The third revolution was the information revolution. It took place between 1960 and 1980, and the significant development was the invention of the personal computer and, with it, the ability to conduct fast and efficient data analysis. It also saw the initiation of the internet infrastructure as we know it today, giving us the ability to store and use an enormous amount of data and information and more (Daemmrich, 2017; Schwab et al., 2016).

The current revolution, the fourth industrial revolution, started at the beginning of the $21^{\text {st }}$ century and described a world where individuals move between digital domains and offline reality with the use of connected technology to enable and manage their lives. This revolution emphasizes the abilities of machines and computers to link and control the physical world (Schwab et al., 2016). However, this revolution is still in its making and represents positive and drastic changes in how we work, live, and do business. It is global and without any physical boundaries in terms of location or geographical center. This revolution is developing at a pace that is much faster and higher in intensity than the previous revolutions. This change will be historic in terms of size, speed, and scope. The drivers of this change are physical, digital, and biological. The physical change is made by autonomous vehicles, 3D printings, robots, and new materials, while the digital change is carried out by IoT and the internet of services. Digitization means automation, which in turn means that companies do not incur diminishing returns to scale, or less of them, at least. To give a sense of what this means at the aggregate level, compare Detroit in 1990 (then a major center of 
traditional industries) with Silicon Valley in 2014. In 1990, the three biggest companies in Detroit had a combined market capitalization of $\$ 36$ billion, revenues of $\$ 250$ billion, and 1.2 million employees. In 2014, the three most leading companies in Silicon Valley had a considerably higher market capital (\$1.09 trillion), generated roughly the same revenues ( $\$ 247$ billion), but with about ten times fewer employees $(137,000)$ (Schwab, 2017; Manyika \& Chui, 2014).

One of the best known and well-used definition of leadership was made by Stogdill (1950), who defined it as "the process (act) of influencing the activities of an organized group in its efforts toward goal setting and goal achievement". This definition regarding the influencing process and its outcome is also acceptable by scholars nowadays (Antonakis et al., 2003; Fiedler, 1996). The term entrepreneurship is generally associated in everyday use with an individual creating a new organization. However, in this research, the term entrepreneurship is used as the principal label to cover all research that involves "the process of uncovering and developing an opportunity to create value through innovation and seizing that opportunity without regard to either resource (human and capital) or the location of the entrepreneur - in a new or existing company" (Churchill, 1992, p. 586; Berends et al., 2016; Denton, 1999; MacVaugh \& Schiavone, 2010). There is a long term debate regarding the optimal set of leadership attributes, but there is no doubt about their importance (Goffee \& Jones, 2006). The entrepreneurial leadership attributes are considered critical factors in addressing challenging conditions and recognizing and exploiting new potential opportunities for the firm (Freeman \& Siegfried, 2015; Harrison et al., 2016).

\section{Methodology}

This research used the content analysis method to extract data about entrepreneur leadership attributes and find the variations between different eras of time and different industrial revolutions. The content analysis method is a qualitative research method that starts with actual observations and the collection of original documents and then proceeded to code layer after layer, employing analysis and comparisons to refine concepts and categories before constructing a systematic theory (Corbin \& Strauss, 1990; Fendt \& Sachs, 2008). Content analysis can analyze written, verbal, or visual communication messages (Krippendorff, 2019; Cole, 1988) and has a long history of use in different academic areas. As a research method, content analysis involves being systematic and using an objective method of describing and quantifying phenomena (Krippendorff, 1980; Sandelowski, 1995; Downe-Wamboldt, 1992).

The content analysis method is more conducive to exploring the entrepreneurs' underlying leadership attributes from documents and other written texts. This method enables us to make validated inferences from different kinds of sources and enables us to condense words into fewer content-related categories. It is assumed that when 
classified into the same groups, words, phrases, and the like share the same meaning (Krippendorff, 2019; Cavanagh 1997). An advantage of this method is that large volumes of textual data and different textual sources can be dealt with and used in collaboration (Elo \& Kyngas, 2008).

\section{Data collection and analysis}

Four firms were chosen for this research, each from a different era of time, as a suitable basis for the current preliminary research. Companies' selection is linked to the four industrial revolutions and based on an era of the innovation' paradigms and theories. Therefore, one company represents the early $20^{\text {th }}$ century; one company was chosen from the years after WW2, one from the 1980s, and finally, one from recent years, after the fourth industrial revolution. Because the industrial revolutions are linked mainly to technology advancement, the firms which included in the data recognized as the top technology leaders, which promote product type of innovation and introduce substantial novelty to the world. The researcher chose this choice of firms as they are considered good representatives of their period: Bell Labs from the first stage of the modern innovation era, Ford from the second industrial revolution, Apple from the third industrial revolution, and Zoom Video from the fourth industrial revolution. The author designed the coding process as part of the content analysis method, which is focused mainly on the leadership attributes that arise from the gathered data.

This study's data was based on digitalized documents and texts from open databases, such as the internet, newspapers, and online digital archives. Those documents include interviews with the firms' CEOs, biographies, and historical descriptions of the firms and their leaders. Therefore, due to this data's focal point, the chosen firm's leadership attributes have been extracted and analyzed. The complete dataset analysis enabled the examination of the changes in those attributes during the time.

\section{Results}

The following section introduces the results and outcome of this research, as well as the leadership attributes of the managers within the firms, while those results provide a better realization of the effect of the fourth industrial revolution on the leaders.

Bell-Labs - Bell Labs was established by AT\&T company and Western electric company in 1925 as the main R\&D unit. Its role was to support the research and development efforts of the country's then-monopolistic telephone company, American Telephone \& Telegraph (AT\&T), which was seeking to create and maintain a system that could connect any person on the globe to any other at any time.

Ford Motors - Ford Motor Company, an American automotive corporation founded in 1903 by Henry Ford and 11 associate investors. The company manufactures passenger 
cars, trucks, and tractors, as well as automotive parts and accessories. Headquarters are in Dearborn, Michigan.

Apple - an American manufacturer of personal computers, computer peripherals, and computer software. It was the first successful personal computer company and the popularizer of the graphical user interface. Headquarters are in Cupertino, California. Apple was established on April 1, 1976, by Steve Jobs and Steve Wozniak. First, the company introduces only circuit board, but after starting to sell full computer, which was much different than where familiar in the market, mainly on its design, the ability to connect it to regular screen (as TV), and ease of use.

Zoom Video - an American communications technology company headquartered in San Jose, California. It provides videotelephony and online chat services through a cloudbased peer-to-peer software platform and is used for teleconferencing, telecommuting, distance education, and social relations. At the beginning of 2020, Zoom's software usage saw a significant global increase following the introduction of quarantine measures adopted in response to the COVID-19 pandemic.

\section{Leadership attributes integration}

To link the leadership attributes to different eras of time, four technology companies were chosen, and by using a content analysis technique, the leadership attributes have been extracted from the data. As part of the data-coding process, the attributes extracted from the data were compared and linked to the acknowledged leadership attributes found in the literature. The extracted leadership attributes from all firms gathered and combined into an integrated database, which enhances the realization of the changes during the time and underscores the effects of the fourth industrial revolution on the leadership attributes.

Results showed the similarities of several leadership attributes, such as self-confidence (3 of 4), leading by example (2 of 4 ), attract excellent teams' member (3 of 4), imagination skills (2 of 4 ), view the large picture (2 of 4 ), focus and competence ( 2 of 4). On the other hand, differences can be also be discovered in several attributes, such as - empathy, choosing people who care, communicating, and endorsing the value of "not reinventing the wheel".

The dominant leadership attributes within the chosen firms were aggregated in Table 1. The dominant leadership attributes were marked with $\sqrt{ }$ sign and highlight the similarities and variations between the chosen firms' attributes. 
Table 1: Leadership attributes summary

\begin{tabular}{lllll}
\hline Leadership Attribute & $\begin{array}{c}\text { Bell- } \\
\text { Labs }\end{array}$ & Ford & $\begin{array}{c}\text { Apple } \\
\text { comp. }\end{array}$ & $\begin{array}{l}\text { Zoom } \\
\text { video }\end{array}$ \\
\hline Self Confidence & $\sqrt{ }$ & $\sqrt{ }$ & & $\sqrt{ }$ \\
Leading by examples & & & $\sqrt{ }$ & $\sqrt{ }$ \\
Attract excellent teams' member & & $\sqrt{ }$ & $\sqrt{ }$ & $\sqrt{ }$ \\
Imagination & $\sqrt{ }$ & $\sqrt{ }$ & \\
View large picture & $\sqrt{ }$ & $\sqrt{ }$ & \\
Focus and competence & & $\sqrt{ }$ & $\sqrt{ }$ \\
Empathy & & & $\sqrt{ }$ \\
Choosing people who care & & & $\sqrt{ }$ \\
Communication & & & $\sqrt{ }$ \\
Value the "not inventing the wheel" & & & $\sqrt{ }$ \\
\hline
\end{tabular}

Source: own compilation

\section{Discussion and recommendations}

The research aims to conduct a pilot survey to check the research question's validity, as the research method purposed tackling the research problem of how the entrepreneur adjusts their leadership attributes to cope with the current fast-changing world. This research answers the research question of the effect of the fourth industrial revolution on entrepreneur leadership attributes? The research results affirm several insights first - the research question can be preliminary answered so. Second, evidence was found that could affirm the tendency of avoiding the willingness to re-develop capabilities that are already existing. This evidence is linked to the preliminary assumption. Third, similarities can be observed in several leadership attributes from the leaders in a different period, which should be investigated further whether they may be adaptive to different technological periods.

\section{Theoretical contribution}

This research aims to link three domains - innovation, entrepreneurship leadership, and the fourth industrial revolution. It steps into an exciting intersection, which has hardly been explored yet, i.e., to answer the question of what changes have been brought in entrepreneur leadership attributes due to the fourth industrial revolution. To answer this question, an intensive literature review was conducted on those main topics. First, regarding innovation and the different types of innovation while concluding the innovation paradigm changes over the last two centuries. Second, regarding the past industrial revolutions and the current ones, their implications, and 
the changes have been. Third, about entrepreneurship and leadership, focusing on leadership's impact on innovation and the attributes that enhance leadership's innovation factor.

A new method to analyze and measure innovation may be introduced according to the results, thus checking the development and changing leadership attributes during the time, particularly in different industrial revolutions. Furthermore, a new perspective to look upon the firm's strategy suggested, mainly the leaders' role to adjust the firm's decision and choices at the innovation pathway. As an outcome of this research, it can be suggested that the leaders choose a collaborative mindset that shares ideas with the eco-system. This mindset may enhance the firm's ability to utilize the knowledge and the products available in the technology eco-system and focus on a more needed project while avoiding waste in unnecessary efforts.

The conclusions also influence how new start-ups can be measured and analyzed, mainly in their first stages. As demonstrated, the pace of technology nowadays, due to the fourth industrial revolution, I s much higher than it was in the past, so the firms should adjust themselves to the changing environment and gain competitive advantages. The research brings impressive leadership attributes that may be used to analyze the firm's leaders and predict its success rate with this current changing economic and technological environment.

\section{Managerial implications}

There are some valuable managerial takeaways in this research from different perspectives. The first for the firm's perspective is the need to train and improve top management and to be adapted to the present day's fast-changing environment. Second, academic institutions should enhance study programs, especially management ones, such as MBAs. Third, venture capital institutes and related funding firms should predict start-up companies' success rate in their earliest stages. This research may help guide them in this process.

The results affirm that the current era of the fourth industrial revolution forces the entrepreneur to adapt and improve their ability to use off-the-shelf technologies, accelerating his firm's innovation. The current entrepreneur must work within a close technological eco-system and share common problems and solutions to utilize the capabilities of the technology that is already available and focus only on the firm's next invention leap. Thus, today's entrepreneurs should be adept at on-the-shelf technology capabilities such as cloud computing, open-source codes, software module sharing with the public, complex algorithms for known problems, and more. A willingness to use them will enhance the firm's ability to keep up with the fast pace of the current revolution. 


\section{Limitations \& directions for future research}

This research's limitations are found in its very nature, as preliminary small-scale research consists only of several firms. The dataset should be broader, and this is the plan for the next research project. Other limitations are concerning the newness of the fourth industrial revolution as it still in progress; therefore, some of the attributes may still be developing. The proposed solution for this is to assure a similar result after the situation stabilizes. Moreover, a limitation also rests in the research method itself, as content analysis extracts the information from the written texts. Thus, this information may be biased, either from the writer's perspective, which may be the leader himself, i.e., in autobiography, or from the writer's perception of the situation, which may differ from the actual situation.

Directions for future research, other than analyzing a much broader sample, may include trying to link the leadership not only to the industrial revolution sequence but also to the industry segment and to the firm's success rate. This research may reveal a deeper layer by linking a specific set of leadership attributes to the market segment, and by combining with the firm's success rate, the outcome may be precious for future understanding of the manager's rule within the firm.

\section{References}

Antonakis, J., Avolio, B. J., \& Sivasubramaniam, N. (2003). Context and leadership: An examination of the nine-factor full-range leadership theory using the Multifactor Leadership Questionnaire. Leadership Quarterly, 14, 261-295

Ballot, G., Fakhfakh, F., Galia, F., \& Salter, A. (2015). The fateful triangle: Complementarities in performance between product, process and organizational innovation in France and the UK. Research Policy, 44(1), 217-232.

Berends, H., Smits, A., Reymen, I., \& Podoynitsyna, K. (2016). Learning while (re)configuring: Business model innovation processes in established firms. Strategic Organization, 14(3), 181-219.

Brown, K., \& Osborne, S. P. (2012). Managing change and innovation in public service organizations. Routledge.

Businessalligators.com (2017). 11 Personality Traits of Henry Ford. Business Alligators. https://www.businessalligators.com/henry-ford-personality-traits/

Cavanagh, S. (1997). Content analysis: concepts, methods and applications. Nurse researcher, $4(3), 5-16$

Churchill, N. C. (1992). Research issues in entrepreneurship. The state of the art of entrepreneurship, 579-596, Boston, MA: PWS-Kent Publishing

Chacko, E. (2020). Eric Yuan's Leadership Lessons for Building Lasting Enterprise Value. Entrepreneur $\mathscr{G}$ Innovation Exchange. https://eiexchange.com/content/eric-yuansleadership-lessons-for-building-lasting-enterprise-va

Christensen, C. (1997). Patterns in the evolution of product competition. European Management Journal, 15(2), 117-127. 
Cole, F. L. (1988). Content analysis: process and application. Clinical nurse specialist, 2(1), 53-57

Corbin, J. M., \& Strauss, A. (1990). Grounded theory research: Procedures, canons, and evaluative criteria. Qualitative sociology, 13(1), 3-21.

Downe-Wamboldt, B. (1992). Content analysis: method, applications, and issues. Health care for women international, 13(3), 313-321

Denton, D.W. (1999). The attraction-selection-attrition model of organizational behavior and the homogeneity of managerial personality. Current Research in Social Psychology, Vol. 4 No. 8, pp. 146-59.

Daemmrich, A. (2017). Invention, innovation systems, and the Fourth Industrial Revolution. Technology $\&$ Innovation, 18(4), 257-265.

Demircioglu, M. A., \& Audretsch, D. B. (2017). Conditions for innovation in public sector organizations. Research policy, 46(9), 1681-1691.

Dosi, G. (2012). Economic coordination and dynamics: Some elements of an alternative evolutionary paradigm (No. 2012/08). LEM Working Paper Series.

Drake, A. (n.d.). 5 Ways to Use Empathy in Leadership From Zoom CEO, Eric Yuan. G2.Com. https://learn.g2.com/hub/reach-2019/eric-yuan

Drucker, P. F. (1988). The coming of the new organization.

Editor. (n.d.). Steve Jobs and the Early Apple Years. Https://Www.iProgrammer.Info/History/People/104-Steve-Jobs-Apple.Html. Retrieved January 17, 2021, from https://www.i-programmer.info/history/people/104-steve-jobs-apple.html

Elo, S., \& Kyngäs, H. (2008). The qualitative content analysis process. Journal of advanced nursing, 62(1), 107-115

Fagerberg, J., Martin, B., \& Andersen, E. S. (2013). Innovation Studies: Evolution \& Future Challenges, $1-230$.

Fendt, J., \& Sachs, W. (2008). Grounded theory method in management research: Users' perspectives. Organizational Research Methods, 11(3), 430-455.

Fiedler, F. E. (1996). Research on leadership selection and training: One view of the future. Administrative science quarterly, 241-250.

Freeman, D., \& Siegfried Jr, R. L. (2015). Entrepreneurial leadership in the context of company start-up and growth. Journal of Leadership Studies, 8(4), 35-39.

Ford inc. (n.d.). Henry Ford Biography. Retrieved from https://corporate.ford.com/articles/history/henry-ford-biography.html

Goffee, R., \& Jones, G. (2006). Getting personal on the topic of leadership: Authentic selfexpression works for those at the top. Human Resource Management International Digest, 14(4), 32-34. https://doi.org/10.1108/09670730610666382

Greenacre, P., Gross, R., \& Speirs, J. (2012). Innovation Theory: A review of the literature. Imperial College Centre for Energy Policy and Technology (ICEPT), (May), 1-49. https://doi.org/10.1016/j.surfcoat.2008.04.067

Harrison, C., Paul, S., \& Burnard, K. (2016). Entrepreneurial Leadership: A Systematic Literature Review. International Review of Entrepreneurship, 14(2), 14(2), 235-264. Retrieved from https://www.researchgate.net/publication/331589807

Henry Ford - Visionaries on Innovation - The Henry Ford. (n.d.), Thehenryford.Org. Retrieved January 17, 2021, from https://www.thehenryford.org/explore/stories-ofinnovation/visionaries/henry-ford/ 
Himmel, R. (2013, April 18). What Personality Traits Made Steve Jobs

Successful? Entrepreneur. https://www.entrepreneur.com/answer/226410

Huddleston, T. (2020, March 30). Zoom's founder left a 6-figure job because he wasn't happy - and following his heart made him a billionaire. CNBC.

https://www.cnbc.com/2019/08/21/zoom-founder-left-job-because-he-wasnt-happybecame-billionaire.html

Khayyat, N. T., \& Lee, J. D. (2015). A measure of technological capabilities for developing countries. Technological Forecasting and Social Change, 92, 210-223.

Krippendorff, K. (1980). Validity in content analysis.

Krippendorff, K. (2019). The changing landscape of content analysis: Reflections on social construction of reality and beyond. Communication 85 Society, 47, 1-27.

Kurzweil, R. (2004). The law of accelerating returns. In Alan Turing: Life and legacy of a great thinker (pp. 381-416). Springer, Berlin, Heidelberg.

Levy, S. (n.d.). Apple Inc. / History, Products, Headquarters, \& Facts. Encyclopedia Britannica. Retrieved from https://www.britannica.com/topic/Apple-Inc

MacVaugh, J., \& Schiavone, F. (2010). Limits to the diffusion of innovation. European journal of innovation management, 13(2), 197-221.

Mantoux, P. (1947). The Industrial Revolution in the Eighteenth Century. The Macmillan Company

Manyika, J., \& Chui, M. (2014). Digital era brings hyperscale challenges. Ft.com. Retrieved 25 March 2021, from https://www.ft.com/content/f30051b2-1e36-11e4-bb6800144 feabdc0.

Merriam-Webster Eds. (Ed.). (2016). The Merriam-Webster Dictionary (Vol. 1st edition). Turtleback.

Noel, V. (2020). Leadership skills and qualities of Steve Jobs, which everyone should learn from. Medium. https://medium.com/@vishalnoel7/top-6-attributes-of-steve-jobs-thatmake-him-a-great-leader-1175eba08e0c

Nye, D. E. (1990). Electrifying America: Social Meaning of a New Technology.

OECD/Eurostat. (2018). Oslo Manual 2018: Guidelines for Collecting, Reporting and Using Data on Innovation, 4th Edition, The Measurement of Scientific, Technological and Innovation Activities. Handbook of Innovation Indicators and Measurement. https://doi.org/10.1787/9789264304604-en

Patel, B. (2018, September 6). "5 CEO Tips On Leading Large Teams" with Zoom's CEO Eric Yuan. Medium. https://medium.com/authority-magazine/5-ceo-tips-on-leadinglarge-teams-with-zooms-ceo-eric-yuan-28d505d045f9

Rajapathirana, R. J., \& Hui, Y. (2018). Relationship between innovation capability, innovation type, and firm performance. Journal of Innovation $\&$ Knowledge, 3(1), 4455 .

Ritchie, H., \& Roser, M. (2017). Technology Adoption. Retrieved from https://ourworldindata.org/technology-adoption

Sandelowski, M. (1995). Qualitative analysis: What it is and how to begin. Research in nursing 83 health, 18(4), 371-375

Schön, D. A. (1967). Technology and change: The new Heraclitus, Oxford: Pergamon Press. 
Schumpeter, J. A. (1934). The Theory Of Economic Development: An Inquiry Into Profits, Capital, Credit, Interest, And The Business Cycle (Harvard Economic Studies).

Harvard University Press.

Schwab, K. (2017). The fourth industrial revolution. Crown Publishing.

Schwab, K. \& World Economic Forum. (2016, January 14). The Fourth Industrial

Revolution: what it means and how to respond. World Economic Forum.

https://www.weforum.org/agenda/2016/01/the-fourth-industrial-revolution-what-itmeans-and-how-to-respond/

The Editors of Encyclopaedia Britannica. (n.d.). Ford Motor Company / History \& Facts. Encyclopedia Britannica. Retrieved from https://www.britannica.com/topic/FordMotor-Company

The Real Leadership Lessons of Steve Jobs. (2014). Harvard Business Review. https://hbr.org/2012/04/the-real-leadership-lessons-of-steve-jobs

Torugsa, N., \& Arundel, A. (2016). Complexity of innovation in the public sector: A workgroup-level analysis of related factors and outcomes. Public Management Review, 18(3), 392-416.

UK Essays. (n.d.). Leadership Traits Of Steve Jobs. UKEssays.Com. Retrieved from https://www.ukessays.com/essays/media/outstanding-leadership-traits-of-steve-jobsmedia-essay.php?vref $=1$

van der Kooij, B. J. J. G. (2013). Innovation Defined: A Survey. SSRN Electronic Journal, (April 2013), 1-48. https://doi.org/10.2139/ssrn.2265782

van der Kooij, B. J. G. (2018). Search for a Common Ground in the Fogs of Innovation Definitions. SSRN Electronic Journal, 1-33. https://doi.org/10.2139/ssrn.3139486

Wikipedia (2021). Zoom Video Communications. Wikipedia. https://en.wikipedia.org/wiki/Zoom_Video_Communications

Wingard, J. (2019, May 16). The Ascent Of Zoom CEO Eric Yuan: Leadership Lessons In Execution \& Authenticity. Forbes.

https://www.forbes.com/sites/jasonwingard/2019/05/15/the-ascent-of-zoom-ceo-ericyuan-holds-leadership-lessons-for-all/?sh $=62686 \mathrm{~d} 2 \mathrm{f} 7393$

Writer, S. (2020, May 22). Bold Leader Spotlight: Henry Ford, Captain of Industry. Bold Business. https://www.boldbusiness.com/human-achievement/bold-leader-spotlighthenry-ford-captain-of-industry/ 


\title{
Are the Robots Going to Take Our Jobs? This Is How American and Hungarian Economists of Generations $Y$ and $\mathrm{Z}$ Conceive the Impact of Artificial Intelligence
}

\author{
KITTI DIÓSSY* \\ *Corvinus University of Budapest, Doctoral School of Business and Management; \\ kitti.diossy@uni-corvinus.hu
}

DOI: $10.14267 / 978-963-503-867-1 \_02$

\begin{abstract}
This paper examines how American and Hungarian economists of generation $\mathrm{Y}$ and $\mathrm{Z}$ view the impact of artificial intelligence (AI) in the short and long term. The choice of topic is motivated by the integration of AI into our everyday lives. Research has been carried out in human resources and social perspectives. Based on the responses of 147 Hungarian and 105 American economists surveyed within the framework of an online, anonymous questionnaire method, a positive vision emerges for young economists. They were confident in the social and economic welfare effects of AI. No significant difference can be found between the thinking of the two generations and the opinion of the nations. The most important conclusion from the empirical results is that AI does not take away the job of economists, but transforms it, and supports to appreciate the virtues of human resources. Accordingly, employers need to develop a shortand long-term action plan to secure their employees' future.
\end{abstract}

Keywords: artificial intelligence, human resources, generations

Funding: The present publication is the outcome of the project „From Talent to Young Researcher project aimed at activities supporting the research career model in higher education," identifier EFOP-3.6.3-VEKOP-16-2017-00007 co-supported by the European Union, Hungary, and the European Social Fund. 


\section{Introduction}

During the daily routine, I often encounter artificial intelligence. The relevance of the research topic is indubitable, but its short-term (5-10 years) and long-term (10-30 years) outcomes are more questionable. Both "layman" and researchers share the question how human resources and artificial intelligence might relate to each other. There will be jobs that disappear, transform, or do not change significantly in the foreseeable future. Thus, the question arises: Are robots going to steal our jobs?

There can be several possible outcomes of the research. At microeconomic level: artificial intelligence could be an additional product, or a replacement product of human resources. The presented scenarios assume completely different economic policy measures. Correspondingly, the companies should have an effective action plan for the upcoming changes.

The research seeks answer what effect artificial intelligence might have on us; and what impact digitization and robotization will have on human work. I examine this question by asking the workers of the future: economists of generations $\mathrm{Y}$ and $\mathrm{Z}$, what they think about the subject. Nevertheless, "we" and the generations that follow us will play a very important role in shaping the coexistence of robots and humans (Zhong, et al., 2017).

My research region is Hungary and the United States, since these countries faithfully represent the view of developed countries where considerable funds are invested in research and development of artificial intelligence and other countries that also developed, but AI support is not a primary concern at the state level. In our country the support of artificial intelligence has not played a prominent role, neither at the national level, nor at the level of the European Union. However, United States is at the forefront of funding R\&D incorporating artificial intelligence (OECD, 2019).

\section{Theoretical background of the research areas and target groups}

The major tools of the Fourth Industrial Revolution will create new opportunities for the development of various processes, have the potential to increase efficiency and productivity, and together will have a significant impact on boosting and modernizing the economy. With artificial intelligence in focus (Mangler, 2015). There is still debate whether artificial intelligence could replace human work. In 2017 Stephan Hawking believed that if they could invent functional and effective artificial intelligence, it would be the most defining "revolutionary" event of the recent times (Tegmark \& Werner, 2018). Robotics and artificial intelligence have been a "hot topic" on the agenda of the recent World Economic Forum too, where economists like Roubini or Stiglitz have also been involved (Dirican, 2015). The convergence of AI and robotics has several potential benefits for science. Laboratory automation systems can physically take advantage of 
techniques used in the field of AI to conduct scientific experiments (OECD, 2019). According to an article by Tegmark Werner (2018), 50\% of jobs is expected to be automated within 20 years. One of the most important issues that preoccupy people today is the Fourth Industrial Revolution and its implications, which will completely subvert the world of companies, HR, and machine-to-human collaboration (Nagy, 2018). Elon Musk has repeatedly warned scientists about the dangers of artificial intelligence. Bill Gates, CEO of Microsoft has also expressed concerns that robots can soar beyond human capabilities in multiple areas (Russell, 2015). However, jobs will not disappear to the extent as previously expected, but the jobs of less educated people are at much greater risk than those of the educated workforce (Arntz, et al., 2016).

In Hungary, supporting artificial intelligence and robotics has boomed in recent years. Hungary is not (yet) at the forefront of the R\&D of artificial intelligence; therefore, the Artificial Intelligence Coalition has been established to improve this situation. The Hungarian AI Coalition was formed in 2018 operating within the framework of the Digital Welfare Program, with the participation of 78 international and domestic companies, universities, scientific workshops, professional and administrative organizations. Its objective is to make Hungary as an important member of the international AI community (Digitális Jóléti Program, 2020). The country's Artificial Intelligence Strategy is expected to contribute $14 \%$, or HUF 7,000 billion, to the country's GDP by 2030 (MTI, 2020). According to the research of PWC (2019), the impact of artificial intelligence will start to be felt in Hungary from the late 2030s.

In the United States, the focus primarily entails top-level IT aspects such as cloudbased computing, Big Data, and virtual reality (VR) (Zhong, et al., 2017). A significant number of previous research pieces in the U.S. and Europe also reports that automation and digitalization can lead to the loss of our future jobs (Arntz, et al., 2016). A study published by Carl Benedikt Frey and Michael Osborne (one of the most cited) (2013) approaches change from a negative side, with $47 \%$ of current jobs (in the USA) threatened with disappearance, so almost every second workplace would be in danger. In contrast, the OECD study estimates a change of only $9 \%$ in developed countries in the proportion of jobs lost due to automation. This poses a serious challenge, as both studies show that low-skilled employees are most at risk (Cséfalvay \& Hlács, 2016). The research concludes that robots would not destroy the work and value of humans in the future, accordingly, we can only argue that it is a transformation.

Today's unresolved question is how to address the expectations of the two youngest age groups in order to share knowledge by meeting their needs (Singh, 2014). After all, information and communication technologies (ICT) are our new "digital age" that will be exploited by generations Y and Z (Seele \& Lock, 2017).

Generation Y (born between 1980 and 1994 (Zemke et al, 2000)) is committed to work, expect immediate feedback and intend to stand on several legs. This is the first "digital" 
generation born into the world of technology, as part of their everyday lives. They are highly qualified in digital skills (Bencsik et al, 2016). They cultivate their relationships primarily on social media and easily accept cultural differences (Törốcsik et al, 2014). The majority of Generation $\mathrm{Y}$ is already present in the labour market and have a university degree. The generation is characterized by 'multitasking' (Bencsik et al, 2016). For them, the concepts of success, career and money are of paramount importance. In order to consider themselves successful in life, their work need to be important, and work-life balance is fundamental (Tari, 2010).

Generation Z (born between 1995 and 2009 (Zemke et al, 2000)) is flexible and smart, tolerant of different cultures, content and knowledge oriented (Törö́csik et al, 2014). It is important to emphasize that Generation $\mathrm{Z}$ is the first global generation in the world (Homo Globalis). Regarding a Forbes magazine survey, it can be argued that the technology is in their blood. It is a careerist, professionally ambitious generation, coupled with technical and a high level of language skills. Therefore, it is an excellent workforce (Bencsik et al, 2016). Today's youth are members of a generation that grows up using the Internet and knows the verbal and visual world of the Internet (Tari, 2011).

A company can be successful if it employs its personnel based on their competencies, skills, abilities, experience, complemented by their personal and individual motivations and principles. Thus, it is key to satisfy their expectations and needs (Bencsik et al, 2016).

\section{Methods}

As a research method, I applied an online questionnaire survey, because this is the most commonly used primary research and information retrieval technique, suitable for descriptive, explanatory and exploratory purposes. Information can be gathered about attitudes, knowledge, opinions, expectations, or experiences. Its advantage is that it is relatively easy to implement, anonymous, so it is easier for people to answer, it usually does not limit the respondents, and properly designed and completed questionnaires provide relevant information (Boncz, 2015).

Altogether 252 people filled the questionnaires, of which 147 were Hungarian and 105 were American. Out of the 252 people, 122 are from generation Y (56 Hungarian and 66 American) and 130 from generation Z (91 Hungarian and 39 American).

My preliminary assumption is that due to generational and $R \& D$ differences in the countries, there could be some variance in the results between the opinions of respondents in the two nations. 


\section{Results}

Based on the theoretical backgrounds I organized my hypotheses into groups to perform the analysis along the following lines: 1) Confidence, motivation and interest 2) Areas affected by artificial intelligence 3) Results for soft and hard skills 4) Relationship between artificial intelligence and human resources 5) Overview and vision of artificial intelligence

All in all, I have not rejected the first hypothesis group, according to which economists are confident in the labour market. However, I have rejected the hypothesis that there is a difference between the motivation of Hungarian and American economists, as there is hardly any difference between the motivation and the factors. I have rejected the hypothesis that AI and robotization have motivating effect on people's work, because it is true that they have a positive approach to it, still it does not motivate them in their work.

In the second group of hypotheses I examined the areas affected by AI. The Hungarians' and Americans' perception of which areas are affected by the artificial intelligence the most in short term is very similar (logistics, engineering area, entertainment, transport, telecommunications). However, in the long term, this consistency does not exist. The Hungarians suppose that space exploration, healthcare and education; while Americans anticipate that healthcare, engineering, transportation and telecommunications will be outstanding. Thus, I reject my hypothesis that young Hungarians and Americans have different views on areas most affected by artificial intelligence in the short term. Nevertheless, the hypothesis that the Hungarian and the American youth's attitudes about areas mostly affected by artificial intelligence in long term, is not rejected, because there are no obvious similarities.

The third group of hypotheses examined the differences in opinions about soft and hard skills. Based on my research, I clearly do not reject the hypothesis that both soft and hard skills are important from the viewpoint of economists. Since both soft and hard skills can be developed, I do not reject it in the case of Americans, but I reject it in the case of Hungarians, therefore I reject the hypothesis overall. In this case, these values have become more valuable in terms of human resources, as they believe that work can only be effective if artificial intelligence and human strength work together.

The fourth group of hypotheses covers a comprehensive area: the relationship between artificial intelligence and human resources. All things considered, I do not reject my hypothesis that, according to the respondents, human work will not cease completely, it will only be transformed. Based on the research results, I do not reject my hypothesis that both American and Hungarian economists have a different opinion in the short and long term on how robots will be like us. As it was clear that from both nations' respondents think in the short term, robots will be moderately or slightly similar, while 
in the long term, they will look like us significantly. In addition, I cannot reject my hypothesis that both American and Hungarian economists believe that there is a difference between short-term and long-term forecasts in the relationship between robots and human resources in the labour market.

The fifth hypothesis group, which examines the AI overall picture, needs further analysis. At this point of the research, I can argue that I cannot observe a significant difference between the American and Hungarian young economists' opinion on the view of artificial intelligence and they have a positive vision about this subject.

Along with my findings in the previous subsection, I continue the research with a deeper and more complex analysis. After analysing the profile of the respondents, I applied the SPSS software to test the established hypotheses, to analyse the data and to prepare interpretations. During the statistical analysis, Association examination, Independent t-test, 5-component factor analysis and Regression model equation were performed, the results of which are described below.

\section{Association study}

In the association examination, based on the Chi-square test, there is an association between two variables if Pearson Chi-square $=0.000<0.05$. The strength of the relationship can be assessed by the Cramer V index: between 0.00 and 0.3 is weak, up to 0.7 is moderate, and 0.7 and above is strong (Hunyadi \& Vita, 2008a).

Summarizing the results, there is a weak relationship:

- between income and generations; between generations and how they think robots will be like us;

- between AI, HR and income;

- between national affiliation and how they think robots will be like us;

- between generations and also nationalities, in the way they think, jobs do not disappear, they are only transformed in the long term;

- between generations and whether they feel threatened by artificial intelligence;

- between nationality and how they think the workplace supports AI;

- between generations and also nationalities, that they believe the government should support more AI;

- between nationality and the fact that they believe that social responsibility will play a greater role;

- between nationality and the fact that they believe the quality of life will increase;

- between nationality and the fact that they believe that the protection of personal rights will play a greater role as a result of AI. 
A strong association can be discovered between national affiliation and perceptions of the relationship between $\mathrm{AI}$ and $\mathrm{HR}$ (Pearson Chi-square $=0.00<0.05$ ). The relationship according to the Cramer V index: 0.737> 0.7 (Hunyadi \& Vita, 2008a).

\section{Independent t-test}

During the independent t-test, I examined the difference between the generations $\mathrm{Y}$ and $\mathrm{Z}$ and the thinking of the Americans and Hungarians.

As a result, there was no significant difference between the opinions of generations such as the thinking of nations on the issues examined: 1) Applying AI at work and 2) Motivation under the influence of AI. The significance level of the tested data was above the $5 \%$ threshold and the $|\mathrm{t}|$ value is less than 1.96 in all cases.

The result corroborates my previous finding that respondents' opinions do not differ on a generational or national basis.

\section{Factor analysis}

During the factor analysis, I formed groups for the attitude test based on 20 questions in the questionnaire. The first 10 questions considered the relationship between AI and human resources, followed by 10 questions about AI and society. I applied factor analysis to globally determine attitudes for the 252 respondents. The statements were rated on a Likert scale with a value of 1-5 (1: strongly disagree, 5: strongly agree), supplemented by an option 0 (I cannot/do not want to answer). I converted the original options $1-5$ to $1-3$ (with 0 additions).

Initially I tested whether the variables were suitable for performing the analysis, and then examined the suitability of the data. This was followed by the determination of the number of factors. Based on the Variance Ratio method 5 components became optimal to provide an explanation of $54.285 \%$ for the entire sample, which exceeds the target of $50 \%$. The Scree plot elbow rule and the Maximum Likelihood method also indicated 5 factors; accordingly, I ran the factor analysis with 5 factors. Based on the obtained results, I performed the rotary factor analysis on the sample. The groups created on the basis of the factors were arranged in descending order according to their size.

The first group included positive questions that affect our lives. In this group, both Hungarian and American respondents were positive $(3+$ values on the Likert scale) about AI.

The second group included negative questions about work. For the negative questions, the respondents did not agree with the statement (3 values on the Likert scale), except 
that they could not clearly judge whether their wages would change, either in a negative or positive direction.

The third group included issues with a positive impact on our society. In this group, the opinions of American and Hungarian economists differed to a certain extent on each issue. According to US respondents, the government should better support R\&D on AI, nevertheless Hungarian respondents still feel less at risk from AI. Young Americans formulated a more positive vision of the social impact of AI and social responsibility compared to the Hungarian respondents.

The fourth group included long-term relevant issues. According to young economists, our lives will clearly change in the positive direction as a result of AI, as our quality of life, and they believe that jobs will not disappear but will change in the long term.

The fifth and final group included questions related to the long-term operation of firms in the light of AI. According to economists, it is profitable for companies to invest in AI in the long term, but the company can function without it.

\section{Regression analysis}

Regression analysis was used to determine the functional positive or negative relationships among variables. Based on the questionnaire, I designated the question examining 10-10 attitudes as independent variables. A dependent variable of the model is how young economists support the use of artificial intelligence in their workplace which was explained by independent variables. In the linear regression model, the explained percentage of the total standard deviation is $54.5 \%$ and the standard error of the estimate is 0.733 , which can be considered as low, making the modelling effort effective. The significance value of the F-test in the ANOVA table is less than 0.05, so there is a relationship. Normality, multicollinearity and auto-correlation tests were also performed with favourable results. Regression model building considered $5 \%$ entry criterion. The significance level of each variable $|\mathrm{t}|$ value was close to zero $(<0.05)$, so the variables had a significant effect on the outcome variable. Tolerance levels were greater than 0.2 and VIF values were less than 3 .

The non-standardized regression equation is the following:

AI support in the workplace $=0,626+0,273 * \mathrm{Q} 1+0,177 * \mathrm{Q} 2+0,080 * \mathrm{Q} 7-0,089$ * $\mathrm{Q} 10+0,170 * \mathrm{Q} 12+0,150 * \mathrm{Q} 13$

- Q1 I would love to work for a company that uses artificial intelligence

- Q2 I would love to learn how to work with robots

- Q7 My workplace supports the use of artificial intelligence 
- Q10 A company can be operational in the long term without artificial intelligence

- Q12 Our daily life is beneficially influenced by artificial intelligence

- Q13 Humanity must adapt to robots and accept the future

The model shows that question 10, that a company can be operational in the long term without the use of AI, has a negative effect on the model. The other variables have a positive effect on the extent to which AI is supported in the workplace. Therefore, with all the other variables unchanged, if fillers prefer to work for a company that uses artificial intelligence, or prefer to learn how to work with robots, they support more the use of artificial intelligence. Respondents argue that our daily lives are more influenced by artificial intelligence or if humanity has to adapt more and more to robots and accept the future, it will induce fillers to be more supportive of the use of artificial intelligence in the workplace.

\section{Discussion and recommendations}

As a summary of my research analysis, I conclude that both Hungarian and American economists of generations $\mathrm{Y}$ and $\mathrm{Z}$ have a significantly positive and optimistic view of the effects of the artificial intelligence.

Regarding the relationship between the younger generations and AI, I can argue that youth believe that our daily lives will be beneficially influenced by AI. They do not feel threatened, since they think that human work will not cease completely, it will only transform and in the short term, robots will complement human resources. However, I would like to mention that artificial intelligence and robotization have no motivating effect on young people during work, and it is not at the key topic of their interests. Attitudes of young economists to AI holds countless opportunities. It seems they would love to work for a company that employs AI and learn how to work with a robot. Furthermore, young Hungarians and Americans have different views on which areas are most affected by artificial intelligence in the short and long term. It is an opportunity that can be exploited in the 21st century because preparing for the change would be profitable for companies in this way. However, I identify as threat that both American and Hungarian economists say that in the long term there will be tasks/jobs that will be performed entirely by robots, and it indicates that some tasks will disappear in the long term. Also, if they are not interested in AI, they will not be involved in research and developments in the near future, although the knowledge of this generation would be essential to develop long-term strategic goals.

Despite the fact that the results of this research have indicated that people do not have a clear vision, still I can truly argue that most of them are optimistic about the topic, regardless of generation and geographical area. 


\section{References}

Arntz, M., Terry, G., \& Ulrich, Z. (2016). The Risk of Automation for Jobs in OECD Countries: A Comparative Analysis: OECD Social, Employment and Migration Working Papers. OECD Publishing. http://dx.doi.org/10.1787/5jlz9h56dvq7-en

Bencsik, A., Horváth-Csikós, T., \& Juhász. (2016). Y and Z Generations at Workplaces. Journal of Competitiveness, 8(3), 90-106.

Boncz, I. (2015). Kutatásmódszertani alapismeretek. Pécsi Tudományegyetem Egészségtudományi Kar.

Cséfalvay, Z., \& Hlács, A. (2016). A jövő munkahelyei: Riasztó számok pesszimizmusa helyett reális helyzetértékelést kínál az OECD. Budapest: Magyarország OECD és UNESCO melletti állandó képviselete. http://oecd.unesco.kormany.hu/a-jovomunkahelyei-riaszto-szamok-pesszimizmusa-helyett-realis-helyzetertekelest-kinal-azoecd

Digitális Jóléti Program. (2020). Mesterséges Intelligencia Koalíció. https://digitalisjoletprogram.hu/hu/tartalom/mesterseges-intelligencia-koalicio

Dirican, C. (2015). The Impacts of Robotics, Artificial Intelligence On Business and Economics. Procedia - Social and Behavioral Sciences, 195, $564-573$.

Frey, C. B., \& Osborne, M. A. (2013). The Future of Employment: How Suspectible are Jobs to Computerization? University of Oxford. In Arntz, M., Gregory, T., Zierahn, U. (2016). The Risk of Automation for Jobs in OECD Countries: A Comparative Analysis: OECD Social, Employment and Migration Working Papers.

Hunyadi, I., \& Vita, L. (2008a). Statisztika I. Aula Kiadó.

Hunyadi, I., \& Vita, L. (2008b). Statisztika II. Aula Kiadó.

Mangler, A. (2015). Az Ipar 4.0-nak igazolnia kell a megtérülését. https://www.elektronet.hu/rendszerintegrator/6383-az-ipar-0-nak-igazolnia-kell-megteruleset

MTI. (2020). Palkovics László: Elkészült a Mesterséges intelligencia stratégia. Origo. https://www.origo.hu/itthon/20200217-palkovics-laszlo-elkeszult-a-mestersegesintelligencia-strategia.html

Nagy, M. (2018). Ipar 4.0: Mindent átformál. Piac és profit. https://piacesprofit.hu/kkv_cegblog/ipar-4-0-az-uj-szabvany/

OECD. (2019). Artificial Intelligence in Society. https://www.oecd-ilibrary.org/science-andtechnology/artificial-intelligence-in-society_eedfee77-en

PWC. (2019). 900 ezer magyar munkahelyet érint a mesterséges intelligencia a következô 15 év alatt. https://www.pwc.com/hu/hu/sajtoszoba/2019/ai_munkaeropiac.html

Russell, S. (2015). What Do You Think about Machines That Think? Edge.

https://www.edge.org/response-detail/26157

Schäffer, B. (2015). A legifjabb titánok. Book Kiadó.

Seele, L., \& Lock, I. (2017). The game-changing potential of digitalization for sustainability: Possibilities, perils, and pathways. Sustain Science, 12, 183-185.

Singh, A. (2014). Challenges and Issues of Generation Z. IOSR Journal of Business and Management, 16(7), 59-63.

Tari, A. (2010). Y generáció. Jaffa Kiadó.

Tari, A. (2011). Z generáció. Tericum Kiadó Kft. 
Tegmark, M., \& Werner, A. C. (2018). ¿La inteligencia artificial nos hará profesionalmente irrelevantes? Gestion. https://gestion.pe/blog/anunciasluegoexistes/2018/05/lainteligencia-artificial-nos-hara-profesionalmente-irrelevantes.html

Törốcsik, M., Szúcs, K., \& Kehl, D. (2014). How Generations Think: Research on Generation Z. Acta Universitatis Sapientiae, Communicatio, 1(2014), 23-45.

Zemke, R., Raines, C., \& Filipczak, B. (2000). Generations at Work: Managing the Clash of Veterans, Boomers, Xers, and Nexters in Your Workplace. New York: American Management Association.

Zhong, R. Y., Xu, X., Klotz, E., \& Newman, S. T. (2017). Intelligent Manufacturing in the Context of Industry 4.0: A Review. Engineering, 616-630. 


\title{
Learning Organizations and Organizational Digital Competencies in the Field of Public Education
}

\author{
NÓRA FAZEKAS* \\ *Corvinus University of Budapest, Department of Management Control; \\ nora.fazekas@uni-corvinus.hu
}

DOI: $10.14267 / 978-963-503-867-1 \_03$

\begin{abstract}
In a constantly changing social, technological, and economic environment, schools not only need to adapt but to learn continuously. One of the most significant and most current fields of school learning in Hungary and worldwide is one of the digital competencies. In this paper, I present the concept of digital competencies and the learning organization, offering an overview of different interpretations and frameworks and draw connections between them. The study suggests interrelations between schools' learning organizational and digital competence capacities and proposes future empirical research on the topic.

Keywords: learning organization, organizational digital competence, school, educational institutions

Funding: The present publication is the outcome of the project "From Talent to Young Researcher project aimed at activities supporting the research career model in higher education," identifier EFOP-3.6.3-VEKOP-16-2017-00007 co-supported by the European Union, Hungary, and the European Social Fund.
\end{abstract}




\section{Introduction}

The rapid advancement of technology reshapes our environment. The ubiquity of digital technologies profoundly changes our lives and our learning processes (Redecker, 2017). More than that: we have to incorporate these into our everyday routines. Digital competence as one of the $21^{\text {st }}$-century skills (Tight, 2020) became essential in being relevant and connected in our knowledge society (Bindé, 2005). Accordingly, schools need to adapt to these new ways of learning and new forms of knowledge.

There has been much support coming from the European Committee's Joint Research Centre (JCR) in the past 15 years providing knowledge, frameworks, and measuring tools for supporting the improvement of digital competencies in the education system. The advancements in this area, as well as practices of educational institutions, can be informative for other sectors.

Working on becoming a learning organization (LO) might just naturally contribute to improving digital competencies as well. I will look at the two concepts in the theoretical background and then see how strengthening organizational learning capacities and building digital competencies are interrelated.

\section{Theoretical background}

\section{Digital Competences}

The concept of digital competencies in connection with carriers of digital technologies is also referred to as ICT (information and communication technologies) literacy and digital literacy in professional materials. There are no widely accepted definitions for these in the literature; terms like digital "skills," "competencies," "aptitudes," "knowledge," "understandings," "dispositions," and "thinking" are also frequently used (Atchoarena et al., 2017). The term digital competence is preferred in this study, as the concept of competence goes beyond the skills of interpretation and use implicated by literacy, comprehension, or thinking, as it includes elements of skill, knowledge, and attitude (Tót, 2017).

Digital competence can be broadly defined as the confident, critical, and creative use of ICT to achieve goals related to work, employability, learning, leisure, inclusion, and participation in society. Digitally competent educational organization refers to the effective use of digital technology by the educational organization and its staff to provide a compelling student experience and to realize a good return on investment in digital technology (Kampylis et al., 2015).

The European Commission's Joint Research Center (EC JRC) has been conducting research on learning in the digital age and related skills since 2005 (Carretero et al., 
2017). The European Digital Competence Framework, also known as DigComp, first appeared in 2013 as a reference for the development and strategic planning of digital competence initiatives. This standard was updated and expanded in 2016 (2.0) and then in 2017 (2.1). Building on this material, in 2015, the framework for educational organizations (DigCompOrg) and in 2017, the digital competence framework for educators (DigCompEdu) was created.

DigCompOrg (Kampylis et al., 2015) is a competence framework for educational institutions that works with seven thematic elements described by 74 indicators: (1) leadership and governance practices, (2) teaching and learning practices, (3) professional development, (4) assessment practices, (5) content and curricula, (6) collaboration and networking and (7) infrastructure. The framework also includes a sector-specific element to leave room for an adequate adaptation of the model.

The approach of DigCompOrg (Kampylis et al., 2015) suggests that the above elements are interconnected and interrelated and are parts of the same whole system. When discussing competence frameworks, the question of measurement rightfully comes forward. The EC JRC created an online tool for voluntary self-assessment based on DigCompOrg, called SELFIE (Self-reflection on Effective Learning by Fostering the Use of Innovative Educational Technologies) that is available in 24 official EU languages.

Complying with EU measures, the Hungarian education system has been taking strategic steps to improve digital competencies. Based on Hungary's Digital Education Strategy (Magyarország Digitális Oktatási Stratégiája, 2016) drown up in 2016, several digitization-related programs are implemented in public education in cooperation with the Educational Authority, the Digital Welfare Nonprofit Ltd. And the Károly Eszterházy University. The development project (EFOP-3.2.15 - VEKOP-17-201700001, Measurement-evaluation and digital developments related to the public education framework, development, and renewal of innovative educational organization procedures) was planned to terminate in October 2020.

Within the project' frame, the Digital Profile System (Digitális Névjegy Rendszer = DNR) for schools was created, based on DigCompOrg and DigCompEdu. DNR (DMPK, 2020) is a complex institutional feedback and development tool suitable for determining the level of digital maturity of schools. The use of the system helps the school to make the most out of digitization. The purpose of the system is multifaceted. It provides information on the digital maturity of the given public education institution and suggests possible development steps in a structured way. DNR also shows the stage of digital transition the school is at, while the system itself supports and reinforces the complex thinking of school actors about all areas of a digitally competent school. It supports the implementation of evidence-based decision-making of school leaders, maintainers, and policy institutions. DNR serves, however, neither qualification nor 
ranking purposes, nor does it replace a deep-reaching development process. The dimensions measured and assessed by DNR are 1) leadership and management practices, 2) digital pedagogical culture, 3) professional development, 4) school digital culture, 5) infrastructure.

\section{The learning organization}

Based on organizational learning theories, the concept of the learning organization offers a view that accepts that organizations, as entities, can learn and that this type of learning is more than the sum of individual learnings. These models provide focus areas for organizational development for the management. Several theoretical frameworks describe this ideal way of being of an organization.

The most fertile era of LO literature comes from the nineties, as a way of answering the calling of the new phenomena knowledge society and knowledge economy, emerging in academic discussion beforehand, in the eighties. If we look at five of the most influential scholarly definitions on the field (Table 1), also discussed by the Oxford Handbook of the Learning Organization (Örtenblad, 2019), we can identify some characteristics of mutual agreement, even though we can identify paradigmatic (Burrell \& Morgan, 1979) differences in the approach of the organization itself: the learning organization is conscious, goal-oriented, supports collective and open-system learning. Employees are empowered, the management is responsible for organizing the necessary structures and processes to nurture this practice and the culture of continuous improvement.

The concept of LO has been very popular with the education sector (Kools \& Stoll, 2016), probably due to the non-competition and non-profit orientation of the LO dimensions. Education management scholars and policy institutions have widely engaged with the model; becoming a LO is now part of the expectations towards educational institutions in the EU and Hungary as well (Okos köznevelés, 2015). In this study, we focus on developments on these two levels.

OECD defines the school as a learning organization (SLO) as an institution that "has the capacity to change and adapt routinely to new environments and circumstances as its members, individually and together, learn their way to realizing their vision" (Kools \& Stoll, 2016, p. 6). This approach aims to bridge related literature and concepts such as "professional learning communities" or "learning environments." Its dimensions are action-oriented, conveying a dynamic view of the LO that is receptive to the local and broader environment. The report emphasizes four transversal themes $(4 \mathrm{~T})$ that influence all LO dimensions: trust, time, technology, and thinking together. 
Table 1: Definitions of the learning organization

\begin{tabular}{|c|c|}
\hline LO scholar(s) & LO definition \\
\hline $\begin{array}{l}\text { Pedler et al. } \\
(1991, \text { p. } 1)\end{array}$ & $\begin{array}{l}\text { "An organization that facilitates the learning of all of its members and } \\
\text { continuously transforms itself to meet its strategic goals." }\end{array}$ \\
\hline $\begin{array}{l}\text { Senge } \\
(1993, \text { p. } 3)\end{array}$ & $\begin{array}{l}\text { "Where people continually expand their capacity to create the results } \\
\text { they truly desire, where new and expansive patterns of thinking are } \\
\text { nurtured, where collective aspiration is set free, and where people are } \\
\text { continuously learning to see the whole together." }\end{array}$ \\
\hline $\begin{array}{l}\text { Garvin } \\
(1993, \text { p. } 80)\end{array}$ & $\begin{array}{l}\text { "An organization skilled at creating, acquiring, and transferring } \\
\text { knowledge, and at modifying its behavior to reflect new knowledge and } \\
\text { insights." }\end{array}$ \\
\hline $\begin{array}{l}\text { Watkins and Marsick } \\
(1996, \text { p. 4) }\end{array}$ & $\begin{array}{l}\text { "One that learns continuously and transforms itself. [...] Learning is a } \\
\text { continuous, strategically used process - integrated with and running } \\
\text { parallel to work." }\end{array}$ \\
\hline $\begin{array}{l}\text { Marquardt } \\
(2011, \text { p. } 247)\end{array}$ & $\begin{array}{l}\text { "A company that learns effectively and collectively and continually } \\
\text { transforms itself for better management and use of knowledge; empowers } \\
\text { people within and outside the organization to learn as they work; utilizes } \\
\text { technology to maximize learning and production." }\end{array}$ \\
\hline
\end{tabular}

Source: own compilation based on Pedler et al. 1991, Senge 1993, Garvin 1993, Watkins and Marsick 1996, Marquardt 2011

In a regional research project of the Hungarian-Netherlands School of Educational. Management (Hungarian abbreviation: KÖVI) (Baráth, 2017) the synchronousdiachronic (SD) LO model (see Figure 1) was designed to be suitable for taking a snapshot of the institutions at a given stage and at a given time in a synchronous manner, and for identifying the school's development path, focusing on evolutionary changes in a diachronic approach. In the center of the synchronous model stands learning and teaching, surrounded by supporting interrelated activity systems. Leadership appears as the outer circle, harmonizing efforts towards the core purpose. The progress of LO maturing is determined by human and organizational factors supporting the organization's learning capacity. 
Figure 1: The synchronous-diachronic model of the school as a learning organization

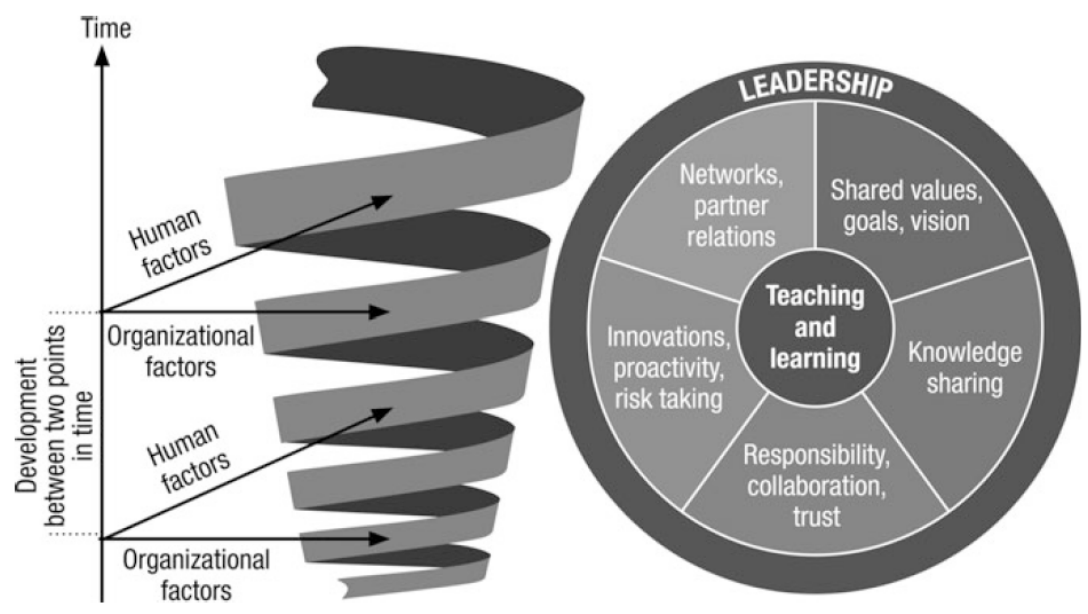

Source: Baráth, 2017 (p. 1189)

In Table 2, the introduced LO concepts' dimensions are displayed, grouped by topic. We can conclude that, as integrative models, the OECD and the Hungarian LO frameworks cover all the fields deemed necessary by former theorists to assess the LO capacity of school organizations. Both the OECD and the SD framework exclude technology as a separate dimension; however, OECD recognizes it as a transversal theme, and the SD model incorporates relevant aspects of digital competence in the sentence list of the measurement tool. Although system thinking as a distinct quality is missing from both models, the theoretical approach of the LO carries it immanently within. 
Table 2: Comparative analysis of learning organization concepts

\begin{tabular}{|c|c|c|c|c|c|}
\hline & Pedler et al. & Senge & Garvin & $\begin{array}{l}\text { Watkins \& } \\
\text { Marsick }\end{array}$ & Marquardt \\
\hline $\begin{array}{l}\text { Innovation, } \\
\text { transformation, } \\
\text { risk-taking }\end{array}$ & $\begin{array}{l}\text { Learning } \\
\text { climate }\end{array}$ & $\begin{array}{l}\text { Mental } \\
\text { models }\end{array}$ & Experimentation & $\begin{array}{l}\text { Inquiry and } \\
\text { dialogue }\end{array}$ & $\begin{array}{c}\text { Organization } \\
\text { transformation }\end{array}$ \\
\hline $\begin{array}{l}\text { Collective } \\
\text { learning, } \\
\text { knowledge } \\
\text { sharing }\end{array}$ & & $\begin{array}{l}\text { Team } \\
\text { learning }\end{array}$ & $\begin{array}{l}\text { Learning from } \\
\text { past experience } \\
\text { Transferring } \\
\text { knowledge }\end{array}$ & Team learning & $\begin{array}{c}\text { Learning } \\
\text { dynamics; } \\
\text { Knowledge } \\
\text { management }\end{array}$ \\
\hline $\begin{array}{l}\text { Common } \\
\text { vision, strategy }\end{array}$ & $\begin{array}{l}\text { Learning } \\
\text { approach to } \\
\text { strategy }\end{array}$ & $\begin{array}{l}\text { Building a } \\
\text { shared } \\
\text { vision }\end{array}$ & & Empowerment & \\
\hline $\begin{array}{l}\text { Individual } \\
\text { development, } \\
\text { empowerment }\end{array}$ & $\begin{array}{c}\text { Self- } \\
\text { development } \\
\text { for everyone }\end{array}$ & $\begin{array}{l}\text { Personal } \\
\text { mastery }\end{array}$ & & $\begin{array}{l}\text { Continuous } \\
\text { learning }\end{array}$ & $\begin{array}{c}\text { People } \\
\text { empowerment }\end{array}$ \\
\hline $\begin{array}{l}\text { Networking, } \\
\text { external } \\
\text { connections }\end{array}$ & $\begin{array}{c}\text { Boundary } \\
\text { workers as } \\
\text { environmental } \\
\text { scanners; } \\
\text { intercompany } \\
\text { learning }\end{array}$ & & $\begin{array}{l}\text { Learning from } \\
\text { others }\end{array}$ & $\begin{array}{l}\text { System } \\
\text { connection }\end{array}$ & \\
\hline $\begin{array}{l}\text { Processes and } \\
\text { structures }\end{array}$ & $\begin{array}{c}\text { Participative } \\
\text { policymaking; } \\
\text { Formative } \\
\text { accounting } \\
\text { and control; } \\
\text { Reward } \\
\text { flexibility; } \\
\text { Internal } \\
\text { exchange; } \\
\text { Enabling } \\
\text { structures }\end{array}$ & & $\begin{array}{c}\text { Systematic } \\
\text { problem solving }\end{array}$ & $\begin{array}{l}\text { Embedded } \\
\text { system }\end{array}$ & \\
\hline Leadership & & & & $\begin{array}{l}\text { Strategic } \\
\text { leadership }\end{array}$ & \\
\hline $\begin{array}{l}\text { Technology, } \\
\text { infrastructure }\end{array}$ & Information & & & & $\begin{array}{l}\text { Technology } \\
\text { application }\end{array}$ \\
\hline $\begin{array}{l}\text { System } \\
\text { thinking }\end{array}$ & & $\begin{array}{l}\text { System } \\
\text { thinking }\end{array}$ & & & \\
\hline
\end{tabular}




\begin{tabular}{|c|c|c|}
\hline & OECD & Baráth \\
\hline $\begin{array}{l}\text { Innovation, } \\
\text { transformation, } \\
\text { risk-taking }\end{array}$ & $\begin{array}{l}\text { Establishing a culture of inquiry, } \\
\text { exploration, and innovation }\end{array}$ & Innovations, proactivity, risk-taking \\
\hline $\begin{array}{l}\text { Collective } \\
\text { learning, } \\
\text { knowledge } \\
\text { sharing }\end{array}$ & $\begin{array}{l}\text { Promoting team learning and } \\
\text { collaboration among all staff }\end{array}$ & Knowledge sharing \\
\hline $\begin{array}{l}\text { Common } \\
\text { vision, strategy }\end{array}$ & $\begin{array}{l}\text { Developing a shared vision centered on } \\
\text { the learning of all students }\end{array}$ & Shared values, goals, vision \\
\hline $\begin{array}{l}\text { Individual } \\
\text { development, } \\
\text { empowerment }\end{array}$ & $\begin{array}{l}\text { Creating and supporting continuous } \\
\text { professional learning for all staff }\end{array}$ & \\
\hline $\begin{array}{l}\text { Networking, } \\
\text { external } \\
\text { connections }\end{array}$ & $\begin{array}{l}\text { Learning with and from the external } \\
\text { environment and more extensive } \\
\text { system }\end{array}$ & Networks, partner relations \\
\hline $\begin{array}{l}\text { Processes and } \\
\text { structures }\end{array}$ & $\begin{array}{l}\text { Embedding systems for collecting and } \\
\text { exchanging knowledge and learning }\end{array}$ & $\begin{array}{c}\text { Responsibility, collaboration, trust; } \\
\text { Teaching and learning }\end{array}$ \\
\hline Leadership & $\begin{array}{c}\text { Modeling and growing learning } \\
\text { leadership }\end{array}$ & Leadership \\
\hline $\begin{array}{l}\text { Technology, } \\
\text { infrastructure }\end{array}$ & & \\
\hline $\begin{array}{l}\text { System } \\
\text { thinking }\end{array}$ & & \\
\hline
\end{tabular}

Source: own editing 


\section{Methods}

The previous section has provided a brief overview of organizational digital competence frameworks and a comparative analysis about learning organization concepts through a narrative literature review (Cronin \& Coughlan, 2008). This type of review enables a comprehensive and critical analysis of current knowledge in the chosen field with the purpose to identify patterns and trends in academic discourse, pointing to gaps and inconsistencies to explore.

\section{Results}

In this section, the interrelations of LO maturity and digital competencies are presented: how do schools' capabilities on these two fields impact each other? To answer this question, we will focus on the introduced Hungarian models of the LO and digital competencies.

\section{How can becoming a learning organization contribute to the school's digital competencies?}

Improving school practices in the dimension of shared values, goals, vision help to create a shared understanding about the role of digital competencies within the school, and to set goals that fit external expectations and at the same time agree with teachers' needs, fears, and technology readiness as well. It allows to shape teachers' attitudes and commitment towards digitalization and to create a welcoming culture both in pedagogical and organizational areas.

Fostering learning leadership, systems of teacher and student evaluation, knowledge sharing and professional development, communication, and relations with internal and external stakeholders, as well as infrastructure management, can become more strategically organized to reach digitalization goals. By developing knowledge-sharing processes and systems, digital innovations and experiences with digital materials or tools can be spread more efficiently within the school. Moreover, if adequate processes, systems, and spaces of knowledge sharing are established, learning in all fields can be accelerated.

Strengthening the culture of innovation, proactivity, and risk-taking will allow school managers and teachers to look for the best digital solutions and empower them to experiment, contributing to pedagogical and organizational renewal and enhancing the school's competitiveness. Building a responsible, collaborative and trustful school community empowers teachers to progress with digital initiatives in a joint, collective 
effort. It cultivates sharing of digital materials, starting new cooperation within and outside of school. It enables responsible ICT and internet usage in the handling of school and personal devices. Building and taking care of network and partner relations helps the school to bring in new digital knowledge and asses its stakeholders' needs of educational service that can or have to be supported via digital solutions.

If teaching and learning are in focus, and the school has its vision about what to provide its stakeholders, it is determined to find and create those kinds of digital assistance that help to realize that vision.

\section{How can a higher level of digital organizational competencies contribute to becoming a $L O$ ?}

Supporting leadership and management processes with digitalization provides the opportunity for school management to make information-based pedagogical, organizational, and operational decisions. It helps to set goals, plan actions and monitor them throughout the process. It helps to create additional platforms of knowledge sharing and knowledge building. Using digital and online platforms for information sharing supports more transparent operations, builds channels of external and network contacts while increasing their quality.

Improving digital pedagogical culture, the possibilities to involve a greater variety of materials and contents grows immensely. It can also enable cross-subject or even crossschool collaborations by establishing the necessary infrastructures. If pedagogical administration is well integrated with school software, learning paths can be monitored that support personalized education.

Digital professional development can raise teachers' engagement with the development of students' learning by new technologies and improve teachers' participation in organizational processes that involve digital platforms. Continuous self-development on the field helps to keep the school up to date too. If the school established in-house digital learning for teachers, like training or mentoring, it could foster community building and a culture of knowledge-sharing. With its growing knowledge, the school can serve as a role model and connect with other schools.

A high level of digital school culture improves the communication flow of the school, and with steady digital cultural and digital ethics knowledge, digital platforms can become secure and trustful environments that nurture collaboration and joint learning of the school staff. 
Infrastructure, if planned and run wisely, will provide the basis for all the internal and external collaboration, access to information and learning, connecting personal and professional spheres of students', parents', and teachers' lives. The proper infrastructure can also help to compensate for missing learning environments and expand it to a global learning room for both staff and students.

\section{Discussion and recommendations}

In this paper, I presented the two concepts of digital organizational competencies and the school as a learning organization. I have introduced definitions and interpretations of digital competence, as well as international and Hungarian progress in addressing and measuring it. I gave an overview about the concept of the learning organization, demonstrated by a comparative analysis, arriving at the model of school as a learning organization. Based on the common approaches of the frameworks, I set out to connect these concepts and suggest explanations, how the two types of organizational capacities can support each other.

In conclusion, research is suggested to test and prove the strength and direction of the causal relationships among the dimensions of a chosen digital competence framework and a learning organization model to identify the most impactful intervention points for organizational improvement. The proposed research can inform school management not only with practical and tangible knowledge but involve specifics of the education sector as well.

\section{References}

Atchoarena, D., Selwyn, N., Chakroun, B., Miao, F. West, \& M., Coligny, C. (2017). Working Group on Education: Digital skills for life and work. Geneva Switzerland, Broadband Commission for Sustainable Development

Baráth, T. (2017). Leading Learning Schools, In Advances in Human Factors, In Kantola, J.I., Barath, T., Nazir, S., Andre, T. (Eds.) Business Management, Training, and Education (pp. 1185-1198). Springer, Cham.

Bindé, J. (2005) Towards knowledge societies: UNESCO world report. PDF file. Online: from https://unesdoc.unesco.org/ark:/48223/pf0000141843. Downloaded: 2020.01.09.

Burrell, G., \& Morgan, G. (1979). Sociological paradigms and organisational analysis: Elements of the sociology of corporate life. Routledge.

DPMK (2020). A Digitális Iskola Kézikönyve [Handbook of the Digital School]. Retrieved January 25, 2021, from https://dnr.dpmk.hu/static/manual/dnr_kezikonyv.pdf 
Carretero, S., Vuorikari, R., \& Punie, Y. (2017). DigComp 2.1: The Digital Competence Framework for Citizens with eight proficiency levels and examples of use (No. JRC106281). Joint Research Centre (Seville site)

Cronin, P., Ryan, F., \& Coughlan, M. (2008). Undertaking a literature review: a step-by-step approach. British Journal of Nursing, 17(1), 38-43.

Garvin, D. A. (1993). Building a Learning Organization. Harvard Business Review, July-August, 78-91.

Kampylis, P., Punie, Y., \& Devine, J. (2015). Promoting effective digital-age learning-A European framework for digitally-competent educational organisations (No. JRC98209). Joint Research Centre (Seville site).

Kools, M., \& Stoll L. (2016). What Makes a School a Learning Organisation? OECD Education Working Papers, No. 137, OECD Publishing, Paris. http://dx.doi.org/10.1787/5jlwm62b3bvh-en

Magyarország Digitális Oktatási Stratégiája [The Digital Education Strategy of Hungary] (2016), Digitális Jólét Program. Retrieved February 18, 2021, from https://digitalisjoletprogram.hu/files/55/8c/558c2bb47626ccb966050debb69f600e.pdf

Marquardt, M. J. (2011). Building the learning organization: mastering the five elements for corporate learning. Hachette Book Group.

Okos Köznevelés: Javaslat a Nemzeti Oktatási Innovációs Rendszer stratégiájának kiegészítéséz, „NOIR+ Stratégia” [Smart Public Education: Suggestions for the National Education Innovation System strategy, „NOIR + Strategy”] (2015), Halász Gábor. Retrieved April 23, 2019, from http://halaszg.ofi.hu/download/A_NOIR_plusz_(2015.07.26)

Örtenblad, A. (Ed.). (2019). The Oxford Handbook of the Learning Organization. Oxford University Press.

Pedler, M., Burgoyne, J. G., \& Boydell, T. (1991). The learning company: a strategy for sustainable development. McGraw-Hill.

Senge, P. M. (1990). The fifth discipline. The art and practice of the learning organization. Doubleday.

Tight, M. (2020). Twenty-first century skills: meaning, usage and value. European Journal of Higher Education, 1-15. https://doi.org/10.1080/21568235.2020.1835517

Tót, É. (2017). Segédlet a tanulási eredmények írásához a felsôoktatási szektor számára [A guide to writing learning outcomes for the higher education sector]; Oktatási Hivatal, Retrieved April 4, 2018, from https://www.oktatas.hu/pub_bin/dload/LLL/ekkr/Tanulasieredmenyek_HE.pdf Watkins, K. E., \& Marsick, V. J. (1996). In action. Creating the Learning Organization. Alexandria VA: American Society for Training and Development. 


\title{
The Signs of Digitalization on Food Safety Issues: A Literature Review Focusing on Traceability
}

\author{
ANNA FREUND* \\ *Corvinus University of Budapest, Department of Logistics and Supply Chain \\ Management; anna.freund@uni-corvinus.hu
}

DOI: $10.14267 / 978-963-503-867-1 \_04$

\begin{abstract}
This study aims to examine the signs of digitalization's/Industry 4.0's impact on food safety in form of a literature review. It is intended to awake the interest of both the academic sphere and internal (e.g., managers) and external (e.g., costumers, state) stakeholders of food producers and also processing companies. The main research questions focus on the methodology of tracing and tracking, which both have significant importance in the area of quality assurance especially in the food industry. From an economic point of view, we are now in the age of Industry 4.0, which has a major impact on the whole economy. Industry 4.0 solutions significantly are realized in the automation of data transfer. Excellent food safety conditions can be supported by real-time transmission, analysis, and interpretation of data characterizing products and processes. This study is an introductory part of the literature review of my doctoral research. The research goals include the exploration of Industry 4.0 and practices given by digitalization within different sectors of the food industry. Furthermore, establishing relationships between the measurability of food safety criteria and the toolbox of digitization and regulatory requirements are expected to be the results of the research process. The current study aims to introduce and interpret the basics of the connection between food safety and the toolbox of Industry 4.0. In general, the research may contribute both to the scientific area and the arena of practice.
\end{abstract}

Keywords: food safety, traceability, digitalization, Industry 4.0

Funding: The author did not receive any grant or institutional support in relation to the study's preparation. 


\section{Introduction}

Nowadays, due to digital technologies and Industry 4.0, which may connect them, the food industry can also be strongly involved in developments aimed at streamlining processes (Nagy, 2019; Nagy, Jámbor, \& Freund, 2020; Oláh, Popp, \& Erdei, 2019). In the current study, the author researches the digital solutions, as she assumes that digitization is the basis of Industry 4.0 (Nagy, 2019; Oláh et al., 2019). The study sees digitalization as a kind of entry-level, which may even be an indispensable starting point for future Industry 4.0 developments. In addition to other pioneering industries (manufacturing, automotive, SSC (shared service centers), logistics..., etc.), digitally coordinated methods and tools have emerged within the food industry, such as traceability, which is the focus of the current study (Demeter et al., 2020). In the following, the role of traceability within the food industry will be clarified, and in connection with it, the system of rules behind food safety will be presented. This part of the doctoral research aims to explore these possibilities and to find the connection between the applicable toolkit and the set of rules that include expectations. Based on the literature review the result of the research is, that the combined application of the three most prominent Industry 4.0 solutions found, CPS (Cyber Physical Systems), IoT (Internet of Things), and blockchain technology (Alladi, Chamola, Parizi, \& Choo, 2019; Bougdira, Akharraz, \& Ahaitouf, 2020; Creydt \& Fischer, 2019; Kayikci, Subramanian, Dora, \& Bhatia, 2020; Khan, Byun, \& Park, 2020; Lee, Azamfar, \& Singh, 2019; Lin, Wang, Pei, \& Wang, 2019; Oztemel \& Gursev, 2020; Prause, Hackfort, \& Lindgren, 2020; Smetana, Aganovic, \& Heinz, 2020; Y. Wang, Han, \& Beynon-Davies, 2019; Yadav, Luthra, \& Garg, 2020) can lead to the most effective implementation of traceability.

\section{Methods}

The author used the systematic literature review methodology set up by Brereton (Brereton, Kitchenham, Budgen, Turner, \& Khalil, 2007) to supplement her existing knowledge. The method describes a scientific validation mechanism. It seems to be applicable in almost any field, thanks to its comprehensive approach. The chapter shows by the author followed steps. 


\section{Research questions}

Three research questions are formulated. They focus on the exploration of the research field.

Q1: What case studies have been conducted in connection with food safety and traceability in the age of Industry 4.0 ?

Q2: Which areas of food safety have already used Industry 4.0 technologies?

Q3: What are the Industry 4.0 solutions that support food safety processes, such as traceability?

\section{Sources}

- Scopus (English speaking keywords)

- Web of Science (English speaking keywords)

- SpringerLink (English speaking keywords)

- Google Scholar (Hungarian speaking keywords)

It is always worth working with multiple search engines to get a comprehensive picture. The found results may be different (Brereton et al., 2007). Besides, where possible, sources should be sought in several languages. While preparing this short paper the author used Hungarian and English keywords.

\section{Keywords}

The author looks for the transferable best practices from the already mentioned industries (where I4.0 solutions are already applied), automotive, manufacturing, SSC, logistics..., etc. Because of this the research examines the various processes of the food industry and aims to find the supporting role of Industry 4.0. The study handles Industry 4.0 as it is "building on technological tools, raising the transparency of processes, integrating the corporate value chain and supply network to a new level, taking customer value creation to a new level, by exploiting the opportunities offered by digitalization and making customized and smart products available" (Nagy, 2019, p. 15). At this stage of the research, the focus within food safety is on traceability, so the following keywords were queried: "traceability" OR "standards" AND "food safety" AND "Industry 4.0". 


\section{Findings}

A total of 67 results in English and 8 in Hungarian were accessible. In addition to the keywords, the author also set the 2015-2020 custom range on each platform as a filter to supplement her existing literature knowledge (applied in previous explorations) with the latest contemporary literature.

\section{Selection of primary studies}

In addition to the expectations derived from the search terms, the author set up the following three criteria to screen the studies: case study or literature review; Hungarian or English speaking; and the scientific quality. The process of selection was the following. Because a manageable amount of resources was screened in both languages, the author read the studies with the above considerations in mind. She considered relevant sources that deal specifically with the monitoring of the food industry (the process did not include the field of agriculture in the analysis framework in the present situation).

\section{Synthesis of literature database}

The author used the methodology described above to supplement her existing funds, which she has already known in connection with traceability. The number of case studies seems to be less significant among the new findings. Experts introduce the topic mostly in the form of literature reviews. The following section describes the literature review.

\section{Theoretical background}

While introducing the theoretical background, three main areas will be in focus. The chapter begins with the basics of traceability. The second paragraph introduces the standards and regulations in connection with traceability. At the end of the literature review, the solutions provided by Industry 4.0 are described, which may contribute to the success of traceability. While introducing the theoretical background three main areas are highlighted.

\section{The role of traceability}

Digitalization might be mainly characterized by data collection, and this fact can be the starting point for product traceability. Traceability and the provision of continuous, realtime data can be the tool, which contributes to meet the needs of food safety standards and consumer trends. Traceability is a tool for monitoring the past, as well as to indicate 
possible intervention, it can be seen as a kind of input for data analysis, which serves as forecasts, and ultimately for prevention (GS1 web page, 2018). The importance of traceability is formulated by researchers, like ,food safety is a significant concern in the modern world; governments need to quickly formulate policies and take various measures to strengthen the management of the safe production of agricultural products, including identification and tracking" (Khan et al., 2020, p. 1).

Based on the collection of Olsen and Borit (Olsen \& Borit, 2013, p. 143) the ISO 8402: 1994, ISO 9000, ISO 22005, EU General Food Law, Codex Alimentarius Commission Procedural Manual (published by $\mathrm{FAO} / \mathrm{WHO}$ ) definitions are worth considering internationally.

Common to all approaches is that they see traceability as an ability to describe transparent, controllable movement between the start and endpoints. However, the difference in connection with ISO approaches is that it is much more general, even ISO 22005, which is a standard specifically for food safety conditions. Presumably, this is since ISO standards can be applied almost anywhere across industries, making the food industry specification less visible. The Codex Alimentarius Commission and the EU regulation focuses on the food supply chain perspective. According to Bougdira, Akharraz, and Ahaitouf (2020) traceability can be understood as a service as well. In the following paragraphs, it is shown, how traceability can be supported by organizations applying Industry 4.0 solutions.

\section{A system of standards that are for ensuring traceability}

Digitalization is based on the collection of data, which is the starting point for product traceability. Food business operators must pay attention to uniform food safety requirements. Behind the food industry, there is a complex system of requirements regarding quality expectations (Hungarian Food Book, HACCP guidelines, GMP (good manufacturing practice) regulation) (elelmiszerlanc.kormany.hu, 2021; Fda.gov.com, 2021; Njt.hu, 2021).

The laws currently in force in Hungary, as well as the relevant regulations, appear in the form of the following. The Hungarian Food Book formulates mandatory regulations, such as the most important HACCP principles and product bases, as well as the collection of testing methods (HACCP web page, 2020; Njt.hu, 2021). Compliance with the guidelines is mandatory for all food business operators. For example, the multi-volume extended

version of this is the GxP regulation developed by the US FDA which contains detailed requirements for all actors in the supply chain for the food and pharmaceutical industries 
(Fda.gov.com, 2021; Raspor, 2008; Wu et al., 2010, p. 45). The FAO / WHO Codex Alimentarius is the globally applied system of standards. Hygiene and technical guidelines have been formulated, and in the case of products intended for human consumption, maximum permitted levels of pesticide residues in food have been stated (FAO web page, 2021). The next one is the GS1 Traceability Standard, which is intended to complement the standards already used (GFSI (Global Food Safety Initiative), ISO), helping to facilitate their application. The GS1 Tracking Standard is considered to be an open standard, aiming to achieve continuity of tracking at the entire supply chain level. The GS1 Standards System creates an information flow linked to the flow of goods, based on three steps: identification, marking, data collection, and sharing (GS1 web page, 2018).

\section{Industry 4.0 toolkit to support compliance with standards}

The concepts of CPS, IoT, cloud, sensors, and blockchain have emerged in the literature concerning the concept of Industry 4.0 (Bibi et al., 2017; Carpenter \& Wyman, 2016; Demeter et al., 2020; Keller, Rosenberg, Brettel, \& Friederichsen, 2014; Tse et al., 2017; G. Wang, Gunasekaran, Ngai, \& Papadopoulos, 2016; Y. Wang et al., 2019). The author hypothesizes that the tools presented can be divided into two main parts, hardware, and software (Demeter et al., 2020; Keller et al., 2014). In addition to the tools that make it suitable for tracking, there is also a need for a sphere through which the processes can function (Nagy et al., 2020). Industrial digitalization is in the middle of the concept. Implementation of this requires hardware that can collect data. On the other hand, the software makes the system suitable for handling data.

Based on these, food products equipped with a network-capable device (chip, RFID, sensor) are suitable for real-time data transmission (Mishra et al., 2016). Big data is generated from the accumulated data, after which the big data analysis can provide decision support assistance, as well as the opportunity for examination, tracking, and possibly intervention (GS1 web page, 2018; G. Wang et al., 2016). The storage of large amounts of data can be provided by cloud-based repositories, while in the case of IoT (Internet of Things) the focus is on the communication of "things". Based on the current systematic literature review, the following Industry 4.0 solutions contribute the most to traceability. 
Table 1. Collected sources

\begin{tabular}{ll}
\hline Area & Authors \\
\hline blockchain & Alladi et al. 2019; Creydt and Fischer 2019; Kayikci et al. 2020; \\
& Khan et al. 2020; Prause et al. 2020 \\
IoT (Internet of Things) & Bougdira et al. 2020; Khan et al. 2020; Prause et al. 2020; \\
& Yadav et al. 2020 \\
CPS (Cyber-Physical Systems) & Bougdira et al. 2020; Lee, Azamfar, and Singh 2019; Oztemel \\
& and Gursev 2020; Smetana et al. 2020 \\
\hline
\end{tabular}

Source: own edition

\section{Blockchain}

Reading the literature, the most frequently mentioned I4.0 solution seems to be the blockchain, which supports food safety processes (Alladi et al., 2019; Creydt \& Fischer, 2019; Kayikci et al., 2020; Khan et al., 2020; Lin et al., 2019). Examining the definitions of blockchain given by the recent theoretical studies, it is conspicuous that the common phrases raising are: traceability, efficiency, and information storage.

„Within the blockchain, a (public) ledger is used for recording the data, as well as the information of each transaction. Information about each completed transaction is stored in a distributed ledger, shared across all the participating nodes of the blockchain network" (Alladi et al., 2019, p. 176935).

According to experts (Beck, Czepluch, Lollike, \& Malone, 2016) the mechanism of blockchain can be described like there are different blocks within the chain connected. Each block contains data about all transactions made within a given period. The technology of blockchain allows that the content of the blocks is not able to be changed retrospectively. It functions as a „digital footprint" and contributes to the validation process of the information. Some experts also state that blockchain can serve ,the transparency from farm to fork" (Creydt \& Fischer, 2019, p. 49).

Blockchain might serve as a sphere, like a virtual space, whereby the hardware tools collected data can be shown and even shared or controlled in real-time (Wang et al., 2019). The research group of Kayicky (Kayikci et al., 2020) adds another perspective to the question regarding food loss and food fraud. Blockchain technology empowers traceability processes to work while avoiding them. Based on this, blockchain as a traceability supporter contributes to raising trust in connection with business transactions providing transparency. 


\section{IoT (Internet of Things)}

Three technologies characterize mostly the operation of the Internet of Things. Sensors (1) record the data of processes and pieces of equipment. To share the data network (2) connection is needed. Cloud (3) technology provides access to the corporate data center. Data can be stored and shared by using clouds (Prause et al., 2020; Yadav et al., 2020). According to the research group of Bougdira, „IoT refers to a set of devices and technologies that could share resources and intelligence" (Bougdira et al., 2020, p. 3355) Experts, like Khan (Khan et al., 2020) explain IoT as a solution, which provides aggregated information produced by the participants of the food supply chain. Based on this IoT is a combined solution, which enables the devices to cooperate and serve the data collection and storage of companies.

\section{CPS (Cyber Physical Systems)}

CPS is comprehensible as a tool, which contributes to the cooperation of human and nonhuman entities within a process. It provides easy communication capability between people, machines, or even products during whole business processes while existing as a link between them (Keller et al., 2014; Oztemel \& Gursev, 2020). According to the research group of Bougdira (Bougdira et al., 2020) CPS is a need to let traceability function within a system. CPS-based solutions are often complex ones. Furthermore, they have an integrative role between the machine word and the cyber computational space (Lee et al., 2019). To CPS belong the usage of RFID tags (ensuring identification), sensors (serving data collection), and also the network, which is the sphere where the collected data can be transported (Oztemel \& Gursev, 2020; Smetana et al., 2020). According to experts (Khan et al., 2020), there are three main areas where the combination of IoT and blockchain technologies can be applied: provenance, payments, and management. Based on this and the previously introduced literature background, it is visible that not only individual parts of solutions exist in connection with traceability. They might cooperate and be combined, such as IoT and blockchain technologies (Kayikci et al., 2020; Khan et al., 2020; Lee et al., 2019; Oztemel \& Gursev, 2020; Prause et al., 2020; Smetana et al., 2020). The author aimed to describe these I4.0 technologies and highlight the importance of customized solutions concerning food safety. 


\section{Conclusion and recommendations}

This literature review aims to highlight the importance of food traceability and show some modern technological solutions, which can contribute to efficient operation. The research questions (Q1, Q2, and Q3) focused on traceability and Industry 4.0 connections. It is visible that Q1 couldn't be answered. Since mainly literature reviews were found (instead of case studies) this lets the author conclude that the researched technologies haven't been frequently applied within the food industry. The literature reviews on the other hand show that various Industry 4.0 solutions are available, so it is worth continuing the research this way. Q2 wanted to examine the areas of food safety, which the researched Industry 4.0 solutions can support. It is was found that mainly traceability, food loss, or even food fraud (Kayikci et al., 2020) are the areas where monitoring, control, feedback, and cost-reduction factors seem to be important. While examining the answers given to Q3, three main Industry 4.0 solutions came up, as specific supporters of food traceability (Alladi et al., 2019; Bougdira et al., 2020; Kayikci et al., 2020; Khan et al., 2020; Lee et al., 2019; Oztemel \& Gursev, 2020; Prause et al., 2020; Smetana et al., 2020). Blockchain, IoT, and CPS solutions were mostly mentioned in the monitored literature. Blockchain was mentioned the most, it is the reason, why it is presented the most in detail. Based on the introduced theories the efficiency of traceability might be able to be increased by combining the I4.0 solutions. There are some difficulties, like that these solutions are rather costly investments and the implementation of the Industry 4.0 solutions would work efficiently, only in case if all of the participants of the food supply chain invested into implementing them. This requirement may cause difficulties.

There are some limitations of the used methodology. Not only case studies or literature reviews should be observed, but also a wider scale of theoretical background should be examined. It could contribute to gain more detailed sources. Widening the language choice (English, Hungarian, German, maybe Russian) would be also a useful decision, to get to know the best practices, existing theories within the examined region. As it is seen, the ratio of the standards and legal requirements is bigger than the introduced solution. Later a change of focus would be also an appropriate choice. Further directions are the research of other supportive solutions of food safety, and the author aims to develop some calculations/guidelines, which may help practitioners in decision making in connection with Industry 4.0 based developments. 


\section{References}

Alladi, T., Chamola, V., Parizi, R. M., \& Choo, K. K. R. (2019). Blockchain Applications for Industry 4.0 and Industrial IoT: A Review. IEEE Access, 7, 176935-176951. https://doi.org/10.1109/ACCESS.2019.2956748

Beck, R., Czepluch, J. S., Lollike, N., \& Malone, S. (2016). Association for Information Systems AIS Electronic Library (AISeL) BLOCKCHAIN - THE GATEWAY TO TRUSTFREE CRYPTOGRAPHIC TRANSACTIONS. Twenty-Fourth European Conference on Information Systems (ECIS), Istanbul, Turkey, 6(May), 4013-4027.

Bibi, F., Guillaume, C., Gontard, N., \& Sorli, B. (2017). A review: RFID technology having sensing aptitudes for food industry and their contribution to tracking and monitoring of food products. Trends in Food Science and Technology, 62, 91-103. https://doi.org/10.1016/j.tifs.2017.01.013

Bottani, E., \& Rizzi, A. (2008). Economical assessment of the impact of RFID technology and EPC system on the fast-moving consumer goods supply chain. International Journal of Production Economics, 112(2), 548-569. https://doi.org/10.1016/j.ijpe.2007.05.007

Bougdira, A., Akharraz, I., \& Ahaitouf, A. (2020). A traceability proposal for industry 4.0. Journal of Ambient Intelligence and Humanized Computing, 11(8), 3355-3369. https://doi.org/10.1007/s12652-019-01532-7

Brereton, P., Kitchenham, B. A., Budgen, D., Turner, M., \& Khalil, M. (2007). Lessons from applying the systematic literature review process within the software engineering domain. Journal of Systems and Software, 80(4), 571-583.

https://doi.org/10.1016/j.jss.2006.07.009

Carpenter, G., \& Wyman, O. (2016). Food manufacturing - Are you ready for Industry 4.0? https://www.marsh.com/uk/insights/research/food-manufacturing-are-you-ready-forindustry.html

Creydt, M., \& Fischer, M. (2019). Blockchain and more - Algorithm driven food traceability. Food Control, 105(March), 45-51. https://doi.org/10.1016/j.foodcont.2019.05.019

Demeter, K., Losonci, D., Marciniak, R., Nagy, J., Móricz, P., Matyusz, Z., ... Diófási-Kovács, O. (2020). Industry 4.0 through the lenses of technology, strategy, and organization A compilation of case study evidence. Vezetéstudomány / Budapest Management Review, 51(11), 14-25. https://doi.org/10.14267/veztud.2020.11.02

elelmiszerlanc.kormany.hu. (2021). https://elelmiszerlanc.kormany.hu/magyar-elelmiszerkonyv FAO web page. (2021). FAO web page. http://www.fao.org/fao-who-codexalimentarius/codextexts/list-standards/en/

Fda.gov.com. (2021). https://www.fda.gov/food/guidanceregulation/cgmp/ucm110907.htm

GS1 web page. (2018). Magyarországi útmutató az élelmiszereknyomonkövetésére vonatkozó elő́rások betartásához.

https://gs1hu.org/data/documents/NENYP_Osszesitett_Utmutato_v1_0_20180418.p $\mathrm{df}$

HACCP web page. (2020). HACCP web page. https://haccpmentor.com/cleaning/gmp-in-thefood-industry/ 
Kayikci, Y., Subramanian, N., Dora, M., \& Bhatia, M. S. (2020). Food supply chain in the era of Industry 4.0: blockchain technology implementation opportunities and impediments from the perspective of people, process, performance, and technology. Production Planning and Control, O(0), 1-21. https://doi.org/10.1080/09537287.2020.1810757

Keller, M., Rosenberg, M., Brettel, M., \& Friederichsen, N. (2014). Bluetooth Based Home Automation System Using Cell Phone Bluetooth Based Home Automation System. International Journal of Mechanical, Aerospace, Industrial, Mechatronic and Manufacturing Engineering, 8(1), 37-44.

Khan, P. W., Byun, Y. C., \& Park, N. (2020). IoT-blockchain enabled optimized provenance system for food industry 4.0 using advanced deep learning. Sensors (Switzerland), 20(10), 1-24. https://doi.org/10.3390/s20102990

Lee, J., Azamfar, M., \& Singh, J. (2019). A blockchain enabled Cyber-Physical System architecture for Industry 4.0 manufacturing systems. Manufacturing Letters, 20, 34-39. https://doi.org/10.1016/j.mfglet.2019.05.003

Lin, Q., Wang, H., Pei, X., \& Wang, J. (2019). Food Safety Traceability System Based on Blockchain and EPCIS. IEEE Access, 7, 20698-20707. https://doi.org/10.1109/ACCESS.2019.2897792

Mishra, D., Gunasekaran, A., Childe, S. J., Papadopoulos, T., Dubey, R., \& Wamba, S. (2016). Vision, applications and future challenges of Internet of Things: A bibliometric study of the recent literature. Industrial Management and Data Systems, 116(7), 1331-1355. https://doi.org/10.1108/IMDS-11-2015-0478

Nagy, J. (2019). Az ipar 4.0 fogalma és kritikus kérdései - vállalati interjúk alapján. Vezetéstudomány / Budapest Management Review, 50(1), 14-26. https://doi.org/10.14267/veztud.2019.01.02

Nagy, J., Jámbor, Z., \& Freund, A. (2020). Az ipar 4.0 és a digitalizáció legjobb gyakorlatai a hazai élelmiszergazdaságban. Vezetéstudomány / Budapest Management Review, 51(6), 5-16. https://doi.org/10.14267/veztud.2020.06.02

Njt.hu. (2021). 152/2009. (XI. 12.) FVM rendelet. Geraadpleegd van http://njt.hu/cgi_bin/njt_doc.cgi?docid=126175.366212

Oláh, J., Popp, J., \& Erdei, E. (2019). A jöv ő kihívásai. LOGISZTIKAI TRENDEK ÉS LEGJOBB GYAKORLATOK, 5(1), 12-19. https://doi.org/10.21405/logtrend.2019.5.1.12

Olsen, P., \& Borit, M. (2013). How to define traceability. Trends in Food Science and Technology, 29(2), 142-150. https://doi.org/10.1016/j.tifs.2012.10.003

Oztemel, E., \& Gursev, S. (2020). Literature review of Industry 4.0 and related technologies. Journal of Intelligent Manufacturing, 31(1), 127-182. https://doi.org/10.1007/s10845018-1433-8

Prause, L., Hackfort, S., \& Lindgren, M. (2020). Digitalization and the third food regime. Agriculture and Human Values, (September). https://doi.org/10.1007/s10460-020-101612

Raspor, P. (2008). Total food chain safety: how good practices can contribute? Trends in Food Science and Technology, 19(8), 405-412. https://doi.org/10.1016/j.tifs.2007.08.009 
Smetana, S., Aganovic, K., \& Heinz, V. (2020). Food Supply Chains as Cyber-Physical Systems: a Path for More Sustainable Personalized Nutrition. Food Engineering Reviews. https://doi.org/10.1007/s12393-020-09243-y

Tse, D., Zhang, B., Yang, Y., Cheng, C., \& Mu, H. (2017). Blockchain application in food supply information security. 2017 IEEE International Conference on Industrial Engineering and Engineering Management. https://doi.org/10.1109/IEEM.2017.8290114

Wang, G., Gunasekaran, A., Ngai, E. W. T., \& Papadopoulos, T. (2016). Big data analytics in logistics and supply chain management: Certain investigations for research and applications. International Journal of Production Economics, 176, 98-110. https://doi.org/10.1016/j.ijpe.2016.03.014

Wang, Y., Han, J. H., \& Beynon-Davies, P. (2019). Understanding blockchain technology for future supply chains: a systematic literature review and research agenda. Supply Chain Management, 24(1), 62-84. https://doi.org/10.1108/SCM-03-2018-0148

Wu, X., Wu, H., Xia, L., Ji, K., Liu, Z., Chen, J., ... Wu, Y. (2010). Socio-technical innovations for total food chain safety during the 2008 Beijing Olympics and Paralympics and beyond. Trends in Food Science and Technology, 21(1), 44-51. https://doi.org/10.1016/j.tifs.2009.10.010

Yadav, S., Luthra, S., \& Garg, D. (2020). Internet of things (IoT) based coordination system in Agri-food supply chain: development of an efficient framework using DEMATEL-ISM. Operations Management Research. https://doi.org/10.1007/s12063-020-00164-x 


\title{
Possibilities of Digitalization and Service Design in the Development of Patient Adherence
}

\author{
DIÁNA NAGY* \\ *Corvinus University of Budapest, Department of Management Control, \\ diana.nagy5@stud.uni-corvinus.hu
}

DOI: 10.14267/978-963-503-867-1_05

\begin{abstract}
In parallel with the development of modern health systems and the growth of the welfare state, diseases have shifted towards chronic diseases. Today, instead of rapid-onset infections, most resources are focused on the long-term treatment of mostly lifelong chronic conditions. The condition for the effective use of therapies is to take the specified dose with the prescribed frequency and for the required period of time. If these parameters are met, we can talk about patient collaboration or adherence. For certain diseases and treatments, adherence is critically low. In the case of complex preparations to be taken several times a day, or diseases that do not cause serious, noticeable complaints, the initial number of patients treated is reduced to a fraction within a short time. As a result, economic harm is perceived not only by the patient but also by all those involved in the health care system, including pharmaceutical companies. However, the factors influencing patient collaboration vary widely. In order to achieve high adherence, the goal is to develop health services that coordinate the actors involved, the infrastructure, the communication, the material components to improve the user experience. As a user-centered methodology, service design can play a prominent role in the design of therapeutic services, contributing to the reduction of uncertainties in innovation processes. In my study, I assess the digital toolkit of patient education in Hungarian society. The aim is to explore digital tools and technologies that can contribute to the development of health awareness and education so that both science and the pharmaceutical and technology companies that exploit it can apply the results of research.
\end{abstract}

Keywords: digitalization, digital transformation, adherence

Funding: The author did not receive any grant or institutional support in relation to the study's preparation. 


\section{Introduction}

Knowledge of the concept of adherence is not new, but there have been few studies on the effectiveness, applicability, and success of therapeutic methods, especially in Hungary, so not only can research fill a gap, but it also provides innovative value to pharmaceutical companies and provides guidance to patients' needs in a broader understanding. However, the factors influencing patient collaboration vary widely. In addition to patient-dependent health status, factors dependent on therapy, socioeconomic, health, and care staff also affect the success of adherence (World Health Organization, 2003).

According to international data, about half of the patients remain on the prescribed therapy (World Health Organization, 2003), the data in Hungary are worse (Molnár, 2011). We would like to examine what kind of digital device and technology could help to increase patient adherence among the Hungarian population in different age groups and different disease groups. The re-exacerbation of the disease, resulting from the discontinuation of therapy after the asymptomatic period (exacerbation), has a significant financial impact: the treatment of outpatient exacerbations is two to three times the cost of proper maintenance therapy. Poor adherence may result in unjustified drug changes, adjunctive therapies, or dose escalation (Berzai, 2017; Molnár \& Dankó, 2010). In addition to the patient, the economic damage is felt by all those involved in the healthcare system, including pharmaceutical companies. Economic burdens attributable to quantified nonadherence result in $\$ 100$ billion in annual spending in the United States (Vermeire et al., 2001), but an estimate from 2011 puts the economic damage caused by a lack of patient cooperation at $\$ 310$ billion (Capgemini Consulting, 2011).

The aim of the research is to explore the possibilities of applying the service design methodology in the design and implementation of user-friendly and experience-based health services. The research provides an opportunity to evaluate the digital educational effectiveness aspect of patients. The significance of the problem is shown by the fact that only 20-50 percent of patients consider cooperation to be appropriate (Molnár, 2011), thus, the social value of the research is enhanced by the fact that the exploration of Hungarian adherence relations on the basis of data affecting a wide population, in as many therapeutic areas as possible, can greatly help the development and successful application of digitally supported, comprehensive, complex therapy management programs. 


\section{Theoretical background}

Thanks to the growing prevalence of digitalization in healthcare as well, the latest technologies are no longer available not only in healthcare institutions but also in our daily lives. The Covid epidemic has brought up to 5-8 years of progress in the digitalization of telemedicine and healthcare. These innovative solutions were already available on the market, but the pandemic has now forced their use (László, 2020). "Pharma digitalization facilitates the healthcare transformation. Pharma digitalization will help the pharma business become more patient-centric. Patients will gain more possibilities for better and cost-effective care outcomes." (Kemppainen \& Liikkanen, 2017).

You can choose from a wide range of different mobile device applications and devices equipped with sensors to measure and record your health data, whether it is related to blood sugar levels or ovulation forecast. What we measured by at-home self-monitoring programs, can be shared immediately with our health care professional, who can remotely monitor and intervene in the therapy in a much more convenient and cost-effective way for both parties. In addition, the existing medical device products can be improved with sensor and connectivity technologies to collect data for further care analytics and personalized therapy (Kemppainen \& Liikkanen, 2017). Moreover, it is now possible to find out about a health issue with the help of a specialist if required. By using the telemedicine service, the number of visits to the doctor can be reduced, waiting times can be avoided and the patient can get answers to his questions in a short time. It is also possible to detect digital biomarkers with high frequency, increasing the importance of health data reliability and digital diagnostics. Such tools may include but are not limited to, so-called wearables as smartwatches, smart bracelets, but also various medical devices, even those that are already operating with an application. The key is for the patient to choose from readily available mobile solutions. "Fluctuations in blood pressure can be linked to events in our lives, we will see how this value changes during sleep or stress events... This can lead to disease prevention. This is where today's "sickness" for patient care turns to "health" for health preservation and prevention." (Szombathelyi, 2020). Measurement of therapeutical adherence can similarly provide accurate information about the positive (or even unfavorable) effects of medication and related treatment on a disease.

Most organizations focus on products and delivery channels. Many resources of organizations (time, budget, logistics) are devoted to outputs to the customer and internal processes (including the experience of the organization's employees) are ignored while service design focuses on these internal processes. Service design enhances the user and employee experience by planning, coordinating, and optimizing the organization's operations to better support customer journeys (Gibbons, 2017). 
It should be noted that it would be easier to develop new products if the exact needs of the customers are well known. According to the World Health Organization (2003), this approach implies the need for patient-tailored interventions. People-centered methodologies, such as design thinking focuses on understanding people's need help to find the most appropriate solution for dedicated problems. First, according to this method, the problem is determined by customer compassion based on prototype generation and experimentation. During the testing process, the solution can be flexibly modified until the product or service is refined.

A way to improve on patient adherence is to reduce the frequency of dosing. Instead of daily or weekly oral dosage forms, monthly, quarterly, or annual dosage forms may be the solution. In addition to making dosing more modern and comfortable, another direction of drug development, aimed at improving therapeutic adherence, is the development of combination drugs to replace several tablets taken in parallel. More convenient delivery devices or easier-to-use medical devices can also improve patient collaboration in practice (Molnár, 2010).

It is also useful for the industry to collect medical devices and data from monitoring, which allows the creation of databases and registers, so we can also filter by disease groups. We can find out how a population produces health status differences according to geological location, so other decision-making mechanisms are needed, for which the system develops models based on the data, using MI algorithms. In the case of a fairly large database, it is possible to analyze the risk on the basis of evidence, to make decisions prepared for the doctor, but also to generate lifestyle suggestions.

\section{Methods}

The main goal of the research is to examine the digital tools of patient education in Hungarian society. Exploring digital tools and technologies that can contribute to the development of health awareness and education, monitoring and measuring therapy for various diseases, so that science as well as pharmaceutical and technology companies can apply the results of research (Papp-Zipernovszky et al., 2016). However, an important goal is to map adherence support solutions for different generations and to find best practices and technologies for each research cohort. There is a lack of such accurate research data in the literature, although it is particularly important how confidently and regularly how different generations of social groups would use such digital tools and solutions, on which healthcare can also build. The aim is also for the research to assess what solutions are currently available to reduce non-adherence and to what segment of society they reach. Examined by location and age, we can get an accurate picture of 
therapeutic adherence related to disease groups by collecting perceptions and therapeutic attitudes. With the analysis of persistence, the degree of cooperation between different diseases, countries, or groups of patients and the factors influencing it to become comparable. In the course of literature research, I first examine the international experience, with special regard to the Central and Eastern European region, and then with company and industry research, I continue to explore the background of the topic, fine-tune the research areas, and research questions. Expert and corporate interviews would be conducted using the method of semi-structured qualitative in-depth interviews, followed by data collection from population questionnaires, quantitative and qualitative data recording, and statistical data analysis. After disseminating the results obtained in this way, preparing case studies and providing feedback to the participants in the research. Summarizing company experiences, formulating proposals and action plans, the aim of which is to provide scientific and professional feedback to the participants in the research.

I evaluate the Hungarian population by participating in activities at a pharmaceutical company and using a questionnaire method. The series of events, already available in 82 cities, also includes free health screenings, counseling, sports programs, and interactive, motivational lectures. Furthermore, to assessing their own health status, visitors are encouraged to participate in support of local health institutions in addition to unnoticed deepening of contact with local professionals. Among other activities of the company, this program provides an opportunity to partially answer research questions, thus providing an excellent opportunity to study the therapeutic adherence habits of the population living in different parts of the country for a wide range of age groups. Questionnaire data collection allows the mapping of participants' attitudes to adherence along a comprehensive study of patient attitudes.

In addition to processing the literature and questionnaires, I would like to gather practical problems and questions through interviews with several experts and target groups that can help determine the effectiveness of adherence, especially the practices and tools used. In this, the literature left many questions open. 


\section{Results}

The design and execution of therapeutic processes play a key role in abandoning therapy. In order to achieve high adherence, the goal is to develop health services that coordinate the actors involved, the infrastructure, the communication, and the material components in order to improve the user experience. Moreover, in addition to patient care, these new solutions can also be used in the field of risk analysis in connection with epidemic data collection. A poorly designed service process can make life particularly difficult for patients with otherwise medical difficulties, which can further worsen adherence. As a usercentered methodology, service design can play a prominent role in the design of therapeutic services, contributing to the reduction of uncertainties in innovation processes.

\section{Discussion and recommendations}

The questions of the research highlight the shortcomings of the sector, and its results are thus suitable for influencing the innovation processes of the partner company and the whole sector, and in a broader sense for a positive effect on the preservation of the health of society. In addition to healthcare providers, the tangible results of the hypothesis testing have a value-creating effect for pharmaceutical companies as well, as it provides input for the development of more focused product and service innovations, as well as their usability in patient-centered lighting. Increasing therapeutic adherence is also reflected at the economic level, but its social benefits are indisputable. Improving health status, increasing age, fewer interventions; requires fewer long-term hospitalizations, thereby relieving the health care chain.

"Patient care data is the new source of innovation and competitiveness for the pharma companies as the real-world evidence. It is obvious that these market challenges and requirements can't be met with the current products, business models, and operations. Therefore, the pharma business transformation is inevitable which will lead to the digitalization of the pharma products, business models, operations and ultimately - the patient care" (Kemppainen \& Liikkanen, 2017).

The research fills a gap in several respects, so it contributes to the fine-tuning of service and product development processes with digital solutions, not only in Hungary but also internationally. Everything, that is done to improve therapy follow-up, has significant social value, as it directly increases the age of the population, improves the quality of life, and reduces the additional costs to the health care system arising from the treatment of worsening diseases. 


\section{References}

Berzai, E. (2017, November 28). A jó gyógyszer csak egy lépcső a gyógyuláshoz vezetô úton. Medicalonline.

http://medicalonline.hu/cikk/a_jo_gyogyszer_csak_egy_lepcso_a_gyogyulashoz_veze to_uton

Capgemini Consulting. (2011). Patient Adherence: The next Frontier in Patient Care, Vision \& Reality 9th Edition, Global Research Report.

László, P. (2020, December 8). Akár 8 éves lemaradást is ledolgozhatott az egészségügy egy év alatt, és a járványnak még nem látszik a vége [Audio podcast episode]. In G77 Podcast. https://g7.hu/podcast/20201208/akar-8-eves-lemaradast-is-ledolgozhatott-azegeszsegugy-egy-ev-alatt-es-a-jarvanynak-meg-nem-latszik-a-vege/

Molnár, M. P. (2010, October 16). Hogyan javítható a beteg-együttmúködés? Pharmaonline Adherencia Tudástár 6. http://pharmaonline.hu/cikk/hogyan_javithato_a_beteg_egyuttmukodes

Molnár, M. P. (2011, June 2). Beteg-együttmúködés és a háttérben meghúzódó tényezók. XIV. Betegbiztonsági Fórum.

Molnár, M. P., \& Dankó D. (2010, Április 9). A beteg-együttmúködés a terápiás siker záloga. Orvostovábbképzö Szemle, 17(4). http://otszonline.hu/cikk/a_beteg_egyuttmukodes_a_terapias_siker_zaloga

Papp-Zipernovszky, O., Náfrádi, L., Schulz, P. J., \& Csabai, M. (2016). „Hogy minden beteg megértse!" - Az egészségmúveltség (health literacy) mérése Magyarországon. Orvosi Hetilap, 157(23). https://doi.org/10.1556/650.2016.30498

Kemppainen, P., \& Liikkanen, S. (2017). Pharma Digitalisation: Challenges and opportunities in transforming the pharma industry. European Pharmaceutical Review.

https://www.europeanpharmaceuticalreview.com/article/51733/pharma-digitalisationchallenges/

Gibbons, S. (2017, July 9). Service Design 101. Nielsen Norman Group (NN/g). https://www.nngroup.com/articles/service-design-101/

Szombathelyi, Zs. (2020, April 2). Digitalizáció az egészségügyben: most fog csak robbanni igazán! Portfolio. https://www.portfolio.hu/gazdasag/20200402/digitalizacio-azegeszsegugyben-most-fog-csak-robbanni-igazan- 422586

Vermeire, E., Hearnshaw, H., van Royen, P., \& Denekens, J. (2001). Patient adherence to treatment: three decades of research. A comprehensive review. Journal of Clinical Pharmacy and Therapeutics, 26(5). https://doi.org/10.1046/j.1365-2710.2001.00363.x

World Health Organization. (2003). Adherence to long-term therapies: evidence for action. ISBN: 9241545992

https://www.who.int/chp/knowledge/publications/adherence_report/en/ 


\title{
The Effects of COVID-19 on the Digital Transformation of the Hungarian Banking Sector
}

\author{
TIBOR TÓTH* \\ *Corvinus University of Budapest, Doctoral School of Business and Management; \\ tibor.toth@stud.uni-corvinus.hu
}

DOI: 10.14267/978-963-503-867-1_06

\begin{abstract}
When choosing the topic, I tried to focus on dealing with such a current and ongoing event, we still don't see the result, and I just find where it develops in three, five, or ten years. Digitization affects all segments and industries to varying degrees, and its impact can be widely demonstrated. Besides, the precarious economic situation resulting from the COVID-19 epidemic further complicates the situation. I found the topic relevant because I am dealing with a phenomenon, a dilemma that directly or indirectly affects everyone and can be useful to a wider audience. During the dissertation, I try to answer the following questions: How does COVID-19 affect the process of digital transformation in the Hungarian banking sector? And how does this affect the collaboration strategies of banks and FinTech companies? In my work, I rely mainly on previous publications and articles by international, prominent researchers. Also, I conducted interviews with Hungarian experts who are currently actively working for Hungarian banks. During the selection of the interviewees, I followed the concept of asking the employees of different financial institutions working at different levels for the most comprehensive picture. In terms of methodology, in addition to processing the interviews and evaluating the literature, I tried to collect and analyze surveys and public data from various commercial banks, regulatory bodies, and major consulting firms. In this article, I have collected trends that have influenced the current state of the banking sector and present the operating environment. In addition to the positive and negative factors influencing the relationship between domestic commercial banks and FinTech companies, I outline a possible scenario for a future digitization strategy for the banking sector. This exploratory research aims to examine the situation and to identify the most important variables and correlations.
\end{abstract}

Keywords: Banking industry, FinTech, digital transformation, COVID-19

Funding: The present publication is the outcome of the project „From Talent to Young Researcher project aimed at activities supporting the research career model in higher education,"identifier EFOP3.6.3-VEKOP-16-2017-00007 co-supported by the European Union, Hungary, and the European Social Fund. 


\section{Introduction}

The main theme for 2020 and probably the coming years is the COVID-19 epidemic. The sudden economic turmoil caused by the epidemic is not only devastating but also has side effects, as human endeavor has triggered demand and supply shocks in almost every area (El-Erian, 2020). The subject of my study is the financial sector is no exception. The main research question is how does COVID-19 affect the process of digital transformation in the Hungarian banking sector? How does this affect the collaboration strategies of banks and FinTech companies?

When choosing the topic, I tried to focus on dealing with such a current and ongoing event, we still do not see the result and we can only guess where it will develop in three, five, or ten years. Digitization affects all segments and industries to varying degrees, and its impact can be widely and demonstrated. Besides, I found the topic relevant because I am dealing with a phenomenon, a dilemma that directly or indirectly affects everyone and can be useful to a wider audience. The situation is further complicated by the precarious economic situation resulting from the COVID-19 pandemic. The situation is new to everyone because since we can talk about digitization, we have not seen a crisis that was not caused by the money market. As the financial institution sector has a history of several centuries and we are talking about a traditional industry, I find it extremely interesting to study how participants are coping with changing market conditions and unprecedented challenges due to digitalization.

In this article, I have collected trends that have influenced the current state of the banking sector and present the operating environment. In addition to the positive and negative factors influencing the relationship between domestic commercial banks and FinTech companies, I outline a possible scenario for a future digitization strategy for the banking sector. The aim of this exploratory research is to examine the situation and to identify the most important variables and correlations.

\section{Theoretical background}

The number of articles published on the topic of digital transformation, which forms the basis of my research, has grown exponentially over the past decade, reflecting the role of digitization in the 21st century. The appearance of FinTech has created further divisions in the subject, with better quality and more comprehensive research articles on digital banking strategies and the relationship between banks and FinTech. Mills and McCarthy (2017) have identified four different strategies that traditional banks can choose to compete or collaborate with online rivals (in some cases, they implement both at the same 
time). These are arm's-length strategy, partnership, build or buy strategy, long-tail strategy. The choice of strategy depends on two factors, one is how much time and money the bank invests in entering the new market, the other in the new digital activity, and the level of integration between operations.

The categorization based on the global survey, which identified four different cooperation models between FinTech companies and banks, is more practice-oriented and much more useful in the analysis of the Hungarian market. During my research, I examine market tendencies along with this categorization, which differentiates in-house development and acquisition, strategic cooperation agreement, and capital investment (Kerényi et al., 2018). Furthermore, for a comprehensive analysis of the topic, it is essential to analyze the audited IFRS and annual reports of commercial banks with a significant role in the market, to examine the studies and analyses carried out by the various regulatory bodies.

Although we are talking about a one-year phenomenon in the case of the COVID-19 epidemic, thousands of scientific articles have already been published, a phenomenon that is of concern to all scientific life. Overall, it can be stated that a number of high-quality publications have been published on the topic, although due to the size of the market, only a few deals specifically with Hungarian market conditions.

\section{Methods}

In my research, I focused on the qualitative research methodology. In addition to the literature review, I also examined the statements of public conferences and round table discussions between professionally credible managers and leaders. In order to get to know the practical operation of the theoretical suggestions, I conducted in-depth interviews with people who are themselves active participants in the processes.

In selecting the interviewees, I followed the concept of asking the staff of different financial institutions working at different levels for the most comprehensive picture. As a result, there were a deputy CEO, a senior manager, an IT developer, and a middleware engineer among the respondents. The questions can be grouped into three major topics. The first issue concerns the current performance of the banking sector and, among other things, I was curious about the differences between the banking markets of Hungary and the surrounding countries in terms of digital development, and what will be the biggest challenges for market participants in the next period. In the following topics, the possibilities and difficulties of cooperating with FinTech startups were highlighted. At the end of the interviews, I addressed the challenges of the digital switchover, including the 
returns, the evaluation of the efforts made so far, and the positive and negative effects of digitalization.

During the data collection, I tried to focus not only on financial indicators but also to derive the factors and recent events that have greatly influenced the development of the segment. In addition to industry specifics, I also analyzed the macro environment. For this, I used not only the IFRS and annual reports of various commercial banks but also interviews and statements from professionals. At this point in the research, I considered two aspects important, on the one hand, credibility (reliable source) and on the other hand diversity. In the process, I made sure that the sources included different interest groups and different perspectives. As a result, the resources include the experiences of market participants and consumers, the views of regulators, various consulting and analysis firms (as external stakeholders), and the views of the scientific community.

\section{Results}

The current crisis cannot be compared to the 2008 financial crisis. On the one hand, as I have already mentioned, the root cause is different, and on the other hand, we do not see the exact end of the current crisis yet. Of course, a parallel can be found between the COVID-19 crisis and the events after 2008. Even in 2008, during the previous recession, many assumed that the effects would be largely localized, at that time in the US and now in China (Elliott, 2020). It quickly became clear that we were wrong, as we were in 2008.

During the first wave, most analysts envisioned a rapid crisis with a V-shaped recovery, but now more and more people are talking about a prolonged correction period. From over 110 CEOs surveyed by The Conference Board, 55\% predicted a U-shaped recovery in Europe over 1-2 years (Ghosh, 2020). According to Baker and Judge (2020), the FinTech world may play a greater role in the global financial intermediation system than before. This is because it is easier to finance the population as well as the micro and small enterprises in the economy.

\section{Banking sector overview}

The general international panic that characterized the first quarter of 2020 caused a $74 \%$ decline in the after-tax profit of the credit institution sector compared to 2019 Q1 otherwise. The deterioration in profitability is mainly related to impairment and provisioning. In the first three quarters of 2020, the Hungarian banking sector achieved a consolidated after-tax profit of HUF 305 billion, which is $54 \%$ of the previous year's figure. Although the ratio of non-performing loans to the moratorium on repayment has always 
decreased, banks have already recorded a net impairment of HUF 294 billion, and the whole thing would be understood at roughly normal levels. The net impairment of the domestic consolidated banking system in the first half of the year is high internationally (MNB, 2020, November). After a stuck period in corporate lending in the first quarter, lending activity is recovering rapidly. The central bank and government loan and guarantee programs support the expansion of lending. In terms of capital position and liquidity, the Hungarian banking system is resistant to even severe economic stress.

The general view of those I interviewed is that the year 2021 will be as difficult and challenging as 2020, yet they are optimistic mainly as far as the processes of digitization are concerned. One of the main drivers of this is the significant increase in consumer acceptance and use of digital financial solutions. As a result of restrictions and lockdowns, cash flow and bank branch visits decreased significantly, and interest in online banking increased. This is supported by a survey conducted by the central bank in the summer of 2020, which shows that almost one-fifth of the online active population is more likely to manage their finances online as a result of the epidemic. Due to these changes, online banking is already the second most widely conducted online activity, preceded only by the use of social media, according to the survey (Danóczy \& Sajtos, 2020).

At the end of 2019 and the beginning of 2020, the central bank assessed the level and preparedness of domestic incumbent banks in two stages. The results of the survey show that although the banking system is aware of the opportunities and challenges of the digital transformation, there is still significant potential for further development. Survey participants the digital development of the banking system is assessed as average overall. The digitalization of internal operations shows a similarly more favorable picture in the sector, while the digitalization of relations with external aspects (digital accessibility of products, developments aimed at digitizing customer relations) needs to be improved on several points. In terms of internal operations, the digitalization of work processes and the digital readiness of the workforce performed best in the case of the domestic banking system (MNB, 2020, April). Compared to the assessment of domestic bank managers, Deloitte's global survey shows a more pessimistic picture of the digital maturity of the sector. During the survey, the key factors were functionality and customer preferences. Based on these, the Hungarian sector belongs to the end of the digital adopter's group. In the Central and Eastern European region, Poland stands out as a digital champion and the Czech Republic as a smart follower. The Hungarian banking sector is broadly at the Croatian and Slovenian levels in terms of the level of services available on digital channels (Deloitte, 2018). 


\section{The position of Fin Tech companies}

One of the key factors influencing the digital maturity of the credit institution sector is the degree of cooperation with FinTech companies. In addition to the incumbents who dominate the vast majority of the domestic financial market, there are currently more than 110 companies registered in Hungary that conduct FinTech business. The domestic FinTech sector has been characterized by dynamic expansion in recent years, which, in addition to the increase in the number of customers, shows a significant increase in the number of employees and sales revenue. Among Hungarian-owned FinTech companies (about three-quarters of the sector), micro and small enterprises dominate, while in the case of foreign-owned firms, the proportion of smaller and larger firms can be considered relatively balanced. Regardless of the ownership structure, the Hungarian FinTech sector is characterized by B2B services, the share of B2C services is less than 10 percent in terms of company number, and they are typically aimed at providing payment services, investments, financing, and insurance (MNB, 2020, April). As the chart shows, only $20 \%$ of companies deal with the service that affects the largest number of retail customers, payment services.

Figure 1: Distribution of the number of FinTech companies per scope of services

\section{Distribution of the number of FinTech companies according to the scope of services}

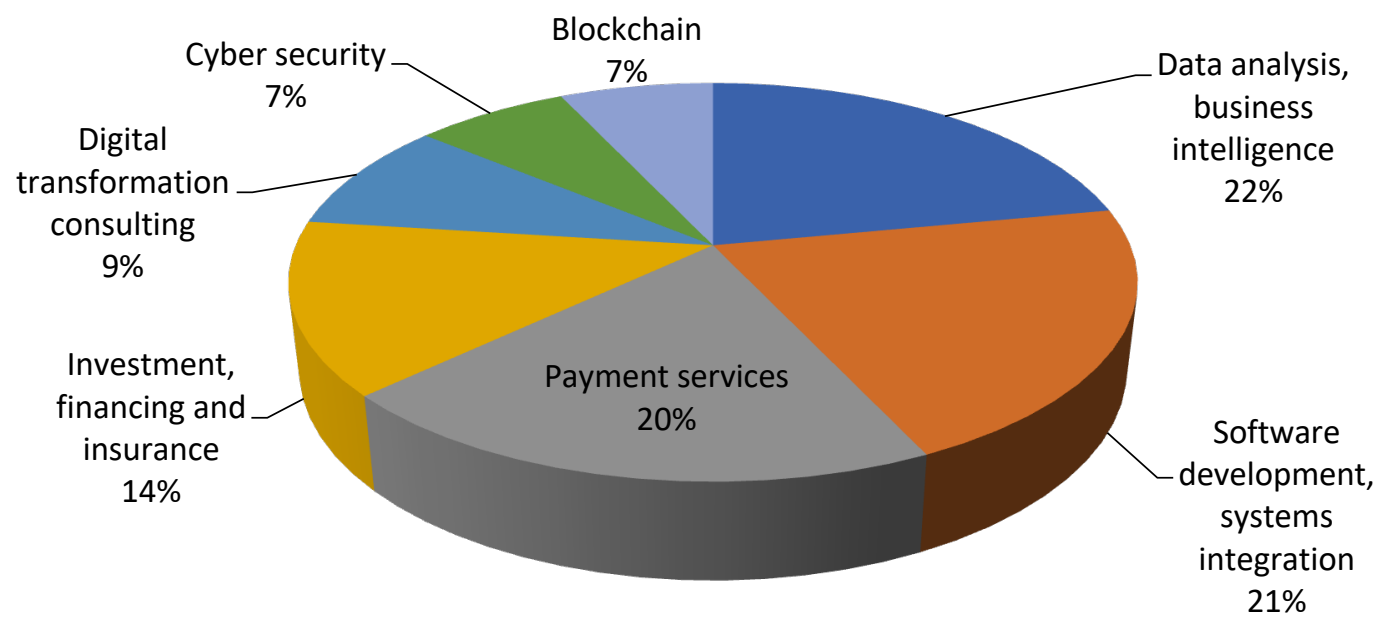

Sources: $M N B, N A V$ 
Cooperation between banks and FinTech companies is still at a fairly early stage in the Hungarian sector. There are serious difficulties in cooperating, the most significant of which are:

- the two types of organizations are characterized by very different corporate cultures, which can be traced mainly to traditions.

- size differences (FinTech is usually a startup with a CEO who multi functionally plays several different roles in the company)

- banks have a hierarchical operation, in most cases, FinTech does not have formalized roles

- a FinTech can respond quickly to emerging needs, be able to improvise (there are no such strict regulations at either the process or IT level as at a bank)

- for a bank, all processes are regulated and controlled

- project management: every bank has an existing project technology that is difficult for a FinTech company to join (Tóth, 2019)

Also, the vast majority of Hungarian banks are characterized by outdated IT core systems, which make it difficult to integrate new, external solutions. Furthermore, the current economic uncertainty may be an obstacle to closer attempts at cooperation, as FinTech companies have no crisis management experience and are facing this type of problem for the first time. The lack of routine in management and a stable financial background makes banks insecure in terms of longer-term forms of cooperation.

\section{Future trends}

Based on the information obtained during the research, in my opinion, the cooperation between banks and FinTech will be even greater shortly. Banks have already recognized the potential of new entrants, and the need for cooperation is not an issue. However, due to the uncertainty caused by the economic situation, these strategies are more about the short-term, targeted for concrete solutions. Instead of long, deep strategic partnerships, the outsourcing of individual sub-tasks or an association with specific projects will be typical. Acquisitions by banks have not been typical solutions in the domestic FinTech sector so far, and there will be no significant change in the coming years. Although we find exciting examples of venture capital investing, the uncertainty of the next 1-2 years is not conducive to investor sentiment.

One of the most positive developments for banks in 2020 is that the online management of any kind of finance is becoming more widespread in Hungary, and in recent years, due to the situation, this has accelerated. As for Danóczy and Sajtos (2020), consumer groups, 
appear in the online banking space who have rigidly rejected this, such as a significant portion of the over-60s. This brought the two most distant groups, retired aged and Generation Z, closer together in terms of consumer behavior. Downsizing of the branch network will sooner or later become inevitable, and currently, a bank branch has fewer and fewer features that cannot be started through an online channel or even a smart ATM. In the long run, this process may also accelerate. However, it is feared that most banks will further delay the replacement of basic IT systems, as they have done in previous years. This can lead to additional complications in integrating new solutions and the reliability of services. Last but not least, banks need to respond to the emergence and growing share of BigTech companies in the Hungarian market, which have huge capital compared to FinTech companies and greater social acceptance.

\section{Conclusion}

The most important question this year is how the processes affecting the core banking activities, such as the ratio of non-performing loans, changes in deposits, and exchange rate policy, will develop. For FinTechs, the key issue is crisis management and building long-term stability. Companies have so far struggled with mistrust and reservations stemming from the state of domestic financial culture. Overall, it can be stated that the Hungarian banking sector currently has a good chance to catch up and work on their disadvantages compared to the region in terms of digital maturity. Although the situation is too complex, there are many variables to say for sure, but in my opinion, the COVID19 epidemic, in addition to its numerous negative social and economic effects, can bring about positive changes in the domestic credit institution sector. For sure, in the coming quarters, it will be worthwhile to follow the intensity of the processes taking place in the sector. There will be some players who will handle new situations very well, the question is whether this will bring significant change at the industry level. 


\section{References}

Baker, T., \& Judge, K. (2020). How to Help Small Businesses Survive COVID-19. Columbia Law and Economics Working Paper, (620).

Deloitte. (2018). Digital Banking Maturity Study EMEA.

https://www2.deloitte.com/hu/en/pages/financial-services/articles/digital-banking-maturityemea.html

Danóczy, B., \& Sajtos, P. (2020). FinTech-ek górcsố alatt: Merre tart a hazai FinTech szektor?. MNB. https://www.mnb.hu/letoltes/danoczy-balint-sajtos-peter-fintech-ek-helyzetemagyarorszagon.pdf

El-Erian, M. A. (2020, March 17). The Coming Coronavirus Recession And the Uncharted Territory Beyond. Foreign Affairs. https://www.foreignaffairs.com/articles/2020-0317/coming-coronavirus-recession

Elliott, L. (2020, March 15). Prepare for the coronavirus global recession. The Guardian. https://www.theguardian.com/business/2020/mar/15/prepare-for-the-coronavirus-global-recession

Ghosh, I. (2020, September 22). This is how the global economy will recover from COVID-19, according to CEOs. World Economic Forum. https://www.weforum.org/agenda/2020/09/covid19-recovery-shape-economy-ceo/

Kerényi, Á., Molnár, J., \& Müller, J. (2018). Veszedelmes viszonyok a bankok és a fintechek között? Gazdaság és Pénzügy, 5(1), 88-99. ISSN 2415-8909

Mills, K., \& McCarthy, B. (2017, April 26). How Banks Can Compete Against an Army of Fintech Startups. Harvard Business Review. https:/hbr.org/2017/04/how-banks-cancompete-against-an-army-of-fintech-startups

MNB. (2020, April). FinTech és digitalizációs jelentés, 2020 április. https://www.mnb.hu/letoltes/fintech-es-digitalizacios-jelente-s-final.pdf

MNB. (2020, November). Pénzügyi stabilitási jelentés, 2020 november. https://www.mnb.hu/letoltes/penzugyi-stabilitasi-jelentes-2020-november.pdf

Tóth, T. (2019). A digitalizáció hatása a magyar bankszektorra, és banki stratégiák a digitális transzformáció tükrében (12616) [Master's thesis, Corvinus University of Budapest]. Corvinus Theses and Outstanding Student Papers. 


\title{
A Relational Foundation of Knowledge Production: Advice-Seeking in Knowledge-Based Organizations
}

\author{
MÁTÉ BAKSA* \\ ${ }^{*}$ Corvinus University of Budapest, Department of Organizational Behavior; \\ mate.baksa@uni-corvinus.hu
}

DOI: 10.14267/978-963-503-867-1_07

\begin{abstract}
In the past decade, the revolutionary advancement of technology brought the attention of academics and management practitioners to the innovative capability of organizations. Companies in knowledgeintensive industries increasingly focus on their ability of self-renewal and adaptation. Concurrently, organizational processes that support the amassment, management, sharing, and employment of knowledge have grown in importance. Organizational social network analysis provides the apparatus to explore knowledge networks in organizations by identifying relationships through which knowledge and information flow. Advice-seeking relationships have an essential role in knowledge production as they enable actors to acquire information, professional support, and knowledge elements they can recombine to form new knowledge. Advice-seeking always assumes trust between actors: by asking for help, one necessarily exposes their weakness to the other. What other relational conditions might there be of advice-seeking in organizational knowledge networks? What are the prerequisites for asking for help? In this paper, I examine the case of two knowledge-based organizations, both located in Hungary: (1) a business services center (390 employees) that offers professional services to B2B partners and (2) a higher education institution (583 employees). I analyzed data collected by a Budapest-based management consultancy that specializes in organizational social network research. I found that most independent variables were significant in the regression models. However, there was a notable difference between each variable's relative explanatory power in the two cases. While process- and decisionrelated relationships seemed essential in the business services center, informal communication and interpersonal trust were more critical for advice-seeking relationships to form in the higher education institution.
\end{abstract}

Keywords: knowledge networks, social network analysis, advice-seeking, knowledge sharing

Funding: The present publication is the outcome of the project "From Talent to Young Researcher project aimed at activities supporting the research career model in higher education,"identifier EFOP3.6.3-VEKOP-16-2017-00007 co-supported by the European Union, Hungary, and the European Social Fund. 


\section{Introduction}

Intensifying global competition has drawn managerial and scholarly attention to the innovative capability of organizations. Companies in the knowledge-based economy put particular efforts into developing their ability to renew and adapt to remain competitive (Csedő et al., 2018; Csedő \& Zavarkó, 2019). Their necessity to become and remain innovative has made the tasks of accumulating, managing, sharing, and applying organizational knowledge more significant than ever before (Bencsik \& Juhász, 2018).

In the past decades, various studies have investigated the development of organizational knowledge management systems (Anand et al., 2007; Natalicchio et al., 2017) as well as the requirements and success criteria for their effective functioning (Bencsik \& Sólyom, 2012; Mas-Machuca \& Martínez-Costa, 2012). Previous studies have also highlighted that the conditions of innovation production have changed considerably: new intellectual content is generated through the collective thinking and cooperation between people with different knowledge (Cheng et al., 2019; Faraj et al., 2015). All of this represents a significant shift from the images of the lonely polymath inventors of the Renaissance or the systematic but still solitary scientists of the Enlightenment and early modernity. Collaborating and knowledge-sharing groups and networks of people have taken the lead (Csontos \& Szabó, 2019).

Effective interpersonal knowledge sharing is one of the most important domains of knowledge management systems. It ensures that the wide range of knowledge present in organizations is available in the right place and at the right time (Park \& Kim, 2018). Therefore, successful knowledge sharing in high value-added, knowledge-based organizations is a precondition of competitiveness (Vohra \& Thomas, 2016). Knowledge sharing is, in many ways, a unique organizational phenomenon. Although it can be influenced by structural incentives (e.g., prizes, cash rewards), people cannot be forced to share their knowledge (Bordia et al., 2006). To facilitate knowledge-sharing, various organizational conditions should be met. One party should recognize their own lack of knowledge and seek advice from another. This requires not only the visibility of the other party's expertise but also their availability, accessibility, and the trust needed to address them (Mas-Machuca \& Martínez-Costa, 2012).

In this paper, I explore the relational conditions of advice-seeking. In doing so, I seek to answer the question of what factors decide to whom members of a knowledge-based organization turn if they need advice. To answer this question, I examined two samples of organizational social network data and used binary logistic regression to identify the most significant relational factors. I conclude that perceived trustworthiness, information, and helpfulness, as well as regular informal communication are all substantial for the 
occurrence of advice-seeking behavior - but with a notable difference between the relative explanatory power of each variable in the two samples.

\section{Theoretical background}

Previous research in the analysis of knowledge networks investigates three observational levels: (i) interpersonal knowledge networks, (ii) intra-organizational (inter-unit) knowledge networks, and (iii) inter-organizational knowledge networks (Csontos \& Szabó, 2019). In this paper, I focus on interpersonal knowledge networks, including the analysis of advice-seeking and knowledge-sharing relationships between network actors. From a network perspective, the actors (nodes) of a knowledge and innovation network are the employees and other stakeholders of the organization, and the relationships (ties) between them represent advice-seeking and cooperation. In these directed or reciprocal (one-way or two-way) relationships, information and emotions flow (Borgatti et al., 2014).

With the tools of organizational network analysis, we are able to analyze patterns of interpersonal interactions in various social networks (Vohra \& Thomas, 2016). A knowledge network is a system of interrelated actors whose primary purpose is to share the knowledge possessed by other actors and create new knowledge (Škerlavaj et al., 2010; Tortoriello et al., 2012). In knowledge networks, an actor may fulfill three functions. First, they might be a knowledge repository (i.e., a knowledge owner) possessing different knowledge elements. Second, they might be an active contributor to the acquisition and transfer of knowledge (i.e., a knowledge broker). Third, might also be the creator of new knowledge elements (i.e., an inventor). Relationships in a knowledge network also serve three functions. First, they are channels through which information flows (Borgatti et al., 2009), and second, they are tools that help to combine knowledge (Škerlavaj et al., 2010). Third, they are filters through which actors view, perceive, and evaluate each other's knowledge (Borgatti \& Cross, 2003).

In a knowledge network, a focal actor (ego) may choose from the members of two groups when asking for advice. They either seek out acquaintances within their existing personal network, or they may turn to actors with whom they have neither personal nor professional relationships but whose knowledge potential they recognized (Nebus, 2006). According to Borgatti and Cross (2003), egos' perception of another actor also influences whom they turn to for knowledge: their judgment is formed by conversations, observations, and other people's opinions.

The visibility of professional expertise strongly influences whom a focal actor turns to for advice (Leonardi, 2015). A network actor seeking advice should also be aware of where 
knowledge is accumulating within the organization and which other actor can help them with a particular issue, that is, who knows what. Borgatti and Cross (2003) also emphasize the significance of knowledge-related judgments. They argue that an advice seeker is more likely to turn to a co-worker for advice if they consider their knowledge valuable.

Considering interpersonal relationships, previous studies have shown that advice seekers often turn to people who are sympathetic to them rather than actual knowledge owners. In their study, Casciaro and Lobo (2005) examined the work choice preference of employees: they wished to know if sympathy or competence is more important. Based on their research findings, personal emotions play a more substantial role in the formation of work-related relationships than the degree of competence. If an employee is disliked, others will be reluctant to work with them, regardless of their visible professional competence (Casciaro \& Lobo, 2005). The selection of the knowledge owner is also affected by the subject of knowledge itself and the nature of the task to be solved. If the task is wellstructured and clear to the seeker, they can better assess the knowledge required for the solution, and this can narrow the range of potential knowledge owners (Nebus, 2006).

Although these previous studies have shown the significance of different relational factors (i.e., layers of the multiplex social reality), their direct effect on advice-seeking behavior remains to be determined. In this paper, the direct contribution of perceived trustworthiness, information, helpfulness, and informal communication is measured in the case of two knowledge-intensive organizations.

\section{Methods}

To answer my research question, I analyzed network data from two knowledge-intensive organizations based in Hungary. Information on the samples (including informal communication network structure) is summarized in Figure 1. The data was collected by Maven Seven Network Research, Inc., a Budapest-based consultancy specialized in organizational network analysis, between 2015 and 2017. The data was anonymized before provided for research purposes. Sample company \#1 operates in the business services sector, while sample company $\# 2$ is a higher education institution. 
Figure 1: Data on sample organizations

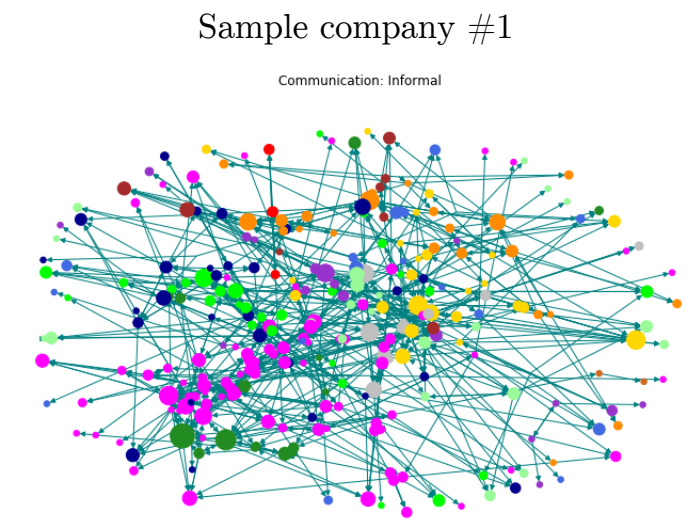

Hungary

Business Services Center

390 employees
Sample company $\# 2$

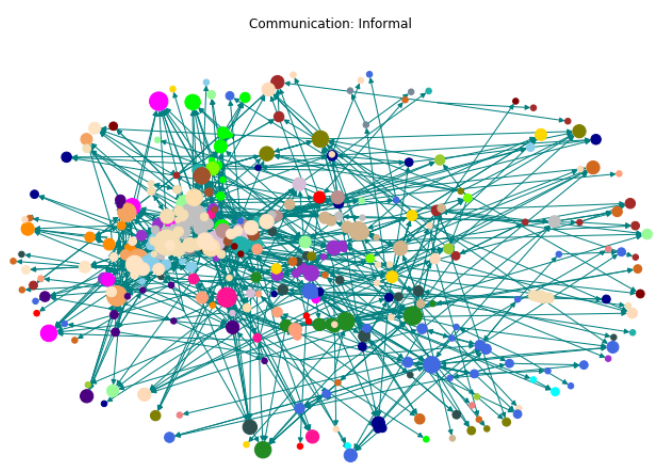

Hungary

Higher Education Institution 583 employees

Source: own editing (Note: in the informal communication networks, colors represent divisional affiliation while node size is proportional with in-degree centrality, i.e., the number of incoming ties)

The two datasets contain network data based on the same self-administered questionnaire in which respondents were asked to name 0-4 co-workers for 18 items. These items are related to different layers of interpersonal relationships and employees' perceptions about each other. Of these layers, five were examined in my analysis at a dyadic level, together with demographic data (division and hierarchy level) and Likert-scale data (formal communication quality). The five relational dimensions (and related survey questions) are as follows:

a) Trustworthy (perceived): Which of your colleagues do you consider trustworthy and dependable?

b) Helpful (perceived): Which of your colleagues is always ready or willing to help others?

c) Informal communication (actual): With whom do you have informal conversations about changes in the organization and processes?

d) Well-informed (perceived): Whom do you consider to be well informed with access to the latest news and updates?

e) Advice-seeking (actual): Whom do you feel comfortable asking for help if you find your work challenging? 
In dyad-level models, the unit of analysis is not an actor but a pair of actors. In this model, an observation is an $i j$ directed dyad, and variables indicate whether actor $i$ chose actor $j$ in a specific relationship dimension. The theoretical maximum of dyads is $n^{*}(n$ 1 ), of which an empirical maximum of $4 n$ could be realized as respondents could name 04 co-workers for each survey question. I used binary logistic regression to evaluate the effects of different relationship types on the emergence of advice-seeking relationships. Data were analyzed by SPSS Statistics 25.

\section{Results}

Binary logistic regression is a type of regression in which the dependent variable is binary $(0,1)$ while independent variables can be nominal, ordinal, or scale variables. It is based on chance rather than probability and assumes a large enough sample size, no multicollinearity between variables, and no extreme values. In my two samples, these assumptions were tested to be true. The regression model included one dependent variable (advice-seeking) and seven independent variables: (a) trustworthiness, (b) perception on information, (c) helpfulness, (d) informal communication between actors, (e) difference in division, (f) difference in the hierarchy, and (g) formal communication quality. Variables (a-e) assume 0 if a relationship is not realized and 1 if it did. Variable (f) assumes value from a $\{-1 ; 0 ; 1\}$ set based on actor i's hierarchic difference from actor $\mathrm{j}$. Variable (g) assume value on a 1-5 interval based on actor's perception.

The explanatory power of the independent variables is summarized in Table 1. The binary logistic regression models had an overall explanatory power between 0,314 (Cox \& Snell $\mathrm{R}^{2}$ ) and 0,424 (Nagelkerke $\mathrm{R}^{2}$ ) in the case of sample company $\# 1$ and 0,240 (Cox \& Snell

$\mathrm{R}^{2}$ ) and 0,371 (Nagelkerke $\mathrm{R}^{2}$ ) in the case of sample company \#2. This model primarily includes variables that model the relational foundations of advice-seeking behavior in organizations and explains about one-third of the total variance. Other internal (individual personality) and external (e.g., organizational structure, culture, and workplace layout) factors are accountable for the rest. 
Table 2: Summary of binary logistic regression model

\begin{tabular}{lcccr}
\hline Variables & \# Sig. & $\# 1 \operatorname{Exp}(\mathrm{B})$ & $\# 2$ Sig. & $\# 2$ Exp(B) \\
\hline (a) Trustworthy & .000 & 2.698 & .000 & 2.215 \\
(b) Well-informed & .000 & 5.153 & .020 & 1.412 \\
(c) Helpful & .000 & 15.895 & .000 & 1.844 \\
(d) Informal communication & .000 & 18.944 & .000 & 4.059 \\
(e) Same division & .635 & .901 & .202 & 1.631 \\
(f) Difference in hierarchy & .692 & .785 & .486 & .922 \\
(g) Formal communication quality & .002 & 1.442 & .998 & .005 \\
\hline
\end{tabular}

Source: own compilation

Relational variables (a-d) were significant in both organizational settings with high explanatory power. In sample company \#1 egos's perception of the alter's trustworthiness, information, helpfulness, and the existence of regular informal communication between them make the realization of advice-seeking behavior in the dyad more likely by 2.698 times, 5.153 times, 15.895 times, and 18.944 times, respectively. It seems that in the business services center, the alter's helpfulness and regular informal communication were the most significant when deciding whom to turn advice for. On the other hand, in sample company \#2, information (1.412) and helpfulness (1.844) were less critical than trustworthiness (2.215) and informal communication (4.059). Differences in division or hierarchy were not significant in either sample. Formal communication quality was significant in sample company $\# 1$ (with the low explanatory power of 1.442 ) but not in sample company $\# 2$.

Based on these samples, it seems that relational dimensions that were supposed to be connected to advice-seeking and knowledge-sharing behavior do explain the appearance of these phenomena. Their difference through the samples may suggest that specific relational dimensions (i.e., layers of the social reality) are more important in this regard in one organization and less in the other. 


\section{Discussion and recommendations}

In this paper, I examined two knowledge-intensive organizations operating in Hungary. Based on previous findings of Casciaro and Lobo (2005) and Mas-Machuca and MartínezCosta (2012), I set out to investigate the relational foundations of advice-seeking relationships. I used data from self-administered social network survey questionnaires and analyzed it on a dyadic level. In this way, I built a binary logistic regression model that explains about one-third of the total variance of the realization of advice-seeking in both organizational samples. In accordance with prior literature, I found that a regular social connection (i.e., informal communication) is significant and the alter's perceived trustworthiness, helpfulness, and information are also essential factors in the formation of advice-seeking ties.

Differences in the explanatory power of the relational variables between the two samples might be due to the different organizational cultures and operational contexts. In a forprofit organization (e.g., a business services center), people are working together and are thus interested in collaboration, knowledge sharing, and advice-seeking. In academia, however, faculty members are working in a competitive environment as they work together but they are competitors at the same time. This may lead to an increased importance of trustworthiness and a decreased explanatory power of other layers of interpersonal relationships.

In conclusion, management practitioners in knowledge-intensive organizations, such as the ones I examined, can increase the likelihood of knowledge sharing by reinforcing trust among employees. They can as well create opportunities for workers to make their expertise visible or formulate and maintain informal relationships. An incentive system that rewards co-workers helping each other may also lead to a higher willingness to advise, which will, in turn, result in a higher probability of asking for help. Through these measures, managers may create an organizational environment that would foster adviceseeking and knowledge sharing and generate innovation. 


\section{References}

Anand, N., Gardner, H. K., \& Morris, T. (2007). Knowledge-Based Innovation: Emergence and Embedding of New Practice Areas in Management Consulting Firms. Academy of Management Journal, 50(2), 406-428. https://doi.org/10.5465/amj.2007.24634457

Bencsik, A., \& Juhász, T. (2018). Tudásorientált szervezetek értékítélete a bizalom gazdasági hatásairól. Vezetéstudomány / Budapest Management Review, 49(1), 30-39. https://doi.org/10.14267/veztud.2018.01.04

Bencsik, A., \& Sólyom, A. (2012). Jön, megy vagy marad? A tacit tudás megőrzésének lehetősége a szervezetben. Munkaügyi Szemle, 56(3), 21-32.

Bordia, P., Irmer, B. E., \& Abusah, D. (2006). Differences in sharing knowledge interpersonally and via databases: The role of evaluation apprehension and perceived benefits. European Journal of Work and Organizational Psychology, 15(3), 262-280. https://doi.org/10.1080/13594320500417784

Borgatti, S. P., Brass, D. J., \& Halgin, D. S. (2014). Social Network Research: Confusions, Criticisms, and Controversies. In Contemporary Perspectives on Organizational Social Networks (pp. 1-29). https://doi.org/10.1108/s0733-558x(2014)0000040001

Borgatti, S. P., \& Cross, R. (2003). A Relational View of Information Seeking and Learning in Social Networks. Management Science, 49(4), 432-445. https://doi.org/10.1287/mnsc.49.4.432.14428

Borgatti, S. P., Mehra, A., Brass, D. J., \& Labianca, G. (2009). Network Analysis in the Social Sciences. Science, 323(5916), 892-895. https://doi.org/10.1126/science.1165821

Casciaro, T., \& Lobo, M. S. (2005). Competent jerks, lovable fools, and the formation of social networks. Harvard Business Review, 83(6), 92-99, 149.

Cheng, J.-H., Huang, J.-K., Zhao, J., \& Wu, P. (2019). Open Innovation: The Role of Organizational Learning Capability, Collaboration, and Knowledge Sharing. International Journal of Organizational Innovation, 11(3), 260-272.

Csedő, Z., \& Zavarkó, M. (2019). Változás, tudás és innováció a vezetéstudományban: elméleti modellek elemzése és értelmezése. Vezetéstudomány / Budapest Management Review, 50(12), 173-184. https://doi.org/10.14267/veztud.2019.12.15

Csedô, Z., Zavarkó, M., \& Sára, Z. (2018). A vállalati innováció által indukált szervezeti változások a magyar energiaszektorban. Vezetéstudomány / Budapest Management Review, 49(2), 53-62. https://doi.org/10.14267/veztud.2018.02.06

Csontos, R. S., \& Szabó, Z. R. (2019). Hálózati tanulás - tanuló hálózatok. Vezetéstudomány / Budapest Management Review, 50(1), 2-13. https://doi.org/10.14267/veztud.2019.01.01

Faraj, S., Kudaravalli, S., \& Wasko, M. (2015). Leading Collaboration in Online Communities. MIS Quarterly, 39(2), 393-412. https://doi.org/10.25300/misq/2015/39.2.06

Leonardi, P. M. (2015). Ambient Awareness and Knowledge Acquisition: Using Social Media to Learn "Who Knows What" and "Who Knows Whom." MIS Quarterly, 39(4), 747-762. https://doi.org/10.25300/misq/2015/39.4.1 
Mas-Machuca, M., \& Martínez-Costa, C. (2012). Exploring critical success factors of knowledge management projects in the consulting sector. Total Quality Management $\mathscr{E}$ Business Excellence, 23(11-12), 1297-1313. https://doi.org/10.1080/14783363.2011.637778

Natalicchio, A., Ardito, L., Savino, T., \& Albino, V. (2017). Managing knowledge assets for open innovation: a systematic literature review. Journal of Knowledge Management, 21(6), 1362-1383. https://doi.org/10.1108/jkm-11-2016-0516

Nebus, J. (2006). Building Collegial Information Networks: A Theory of Advice Network Generation. Academy of Management Review, 31(3), 615-637. https://doi.org/10.5465/amr.2006.21318921

Park, S., \& Kim, E.-J. (2018). Fostering organizational learning through leadership and knowledge sharing. Journal of Knowledge Management, 22(6), 1408-1423. https://doi.org/10.1108/jkm-10-2017-0467

Škerlavaj, M., Dimovski, V., \& Desouza, K. C. (2010). Patterns and Structures of Intraorganizational Learning Networks within a Knowledge-Intensive Organization. Journal of Information Technology, 25(2), 189-204. https://doi.org/10.1057/jit.2010.3

Tortoriello, M., Reagans, R., \& McEvily, B. (2012). Bridging the Knowledge Gap: The Influence of Strong Ties, Network Cohesion, and Network Range on the Transfer of Knowledge Between Organizational Units. Organization Science, 23(4), 1024-1039. https://doi.org/10.1287/orsc.1110.0688

Vohra, N., \& Thomas, N. (2016). Investigating Organizational Learning through Social Network Analysis: The Case of a Consultancy Firm in India. Thunderbird International Business Review, 58(6), 587-600. https://doi.org/10.1002/tie.21777 


\title{
Retention of Millennials in the Voluntary Sector: How Can Organizations Not Only Engage but Also Retain This Emerging Generation?
}

\author{
SÁRA FORGÁCS-FÁBIÁN* \\ *Corvinus University of Budapest, Department of Management and Organization, \\ sara.fabian@uni-corvinus.hu
}

DOI: 10.14267/978-963-503-867-1_08

\begin{abstract}
Why do emerging generations stay active in a voluntary organization? The number of volunteers is increasing in Hungary, one reason is the obligatory community service in secondary schools. There is an emerging generation who has experience in volunteering, however there is a little knowledge about why they sustain voluntary work. Although previous studies elaborate on the retention of volunteers from a general perspective, further research is needed in this specific area. This study aims to examine younger generations' (Millennials, GenY) retention in nonprofit voluntary organizations by conducting a single case study at Amigos for Children Foundation, in Hungary. Adopting a grounded theory approach, the study aims to build theory on the topic by combining two streams of literature with primary data: sustained volunteerism and expectations of younger generations towards their workplace. Based on prior literature review and qualitative research, findings suggest that organizations should focus on two main areas to keep younger generations motivated. (1) Organizational factors in which volunteering happens are flexible framework for daily operations, flat organization, involvement in decision making and opportunity for shaping the organization. (2) What the volunteer gets in exchange for the prosocial activity: positive feedback, recognition, strong community, opportunity for social and professional development, autonomy, responsibility, mutual trust. An important finding of the study is that younger generations are conscious about the values and the organization itself they work or volunteer at. Further, one of the most important factors for them is the community they do prosocial activity with. Overall, the current study develops propositions on organizational factors to retain younger generations in voluntary organizations.
\end{abstract}

Keywords: nonprofit sector, volunteer retention, Millennial generation, management

Funding: The present publication is the outcome of the project „From Talent to Young Researcher project aimed at activities supporting the research career model in higher education,"identifier EFOP3.6.3-VEKOP-16-2017-00007 co-supported by the European Union, Hungary, and the European Social Fund. 


\section{Introduction}

Volunteering is becoming more popular as people discover the happiness and well-being that volunteering brings (Vecina and Chacón, 2013). But the question why volunteers, especially of generation Millennial, remain in a particular charity organization, continues to be unanswered.

First, there is an increasing attention towards volunteerism (Carpenter and Myers 2010, Aydinli et al. 2014, Geiser, Okun and Grano 2014) second, generational differences between $\mathrm{X}, \mathrm{Y}$ (Millennials) and $\mathrm{Z}$ generations, is also becoming a relevant and an interesting topic (Smith 2010, Twenge 2010, Aruna and Anitha 2015) and third, there is a significant body of research about the expectations and needs of Millennials regarding their workplace and career development (Broadbridge et al., 2007; Luscombe et al., 2013; Aruna and Anitha, 2015). However, the combination of these fields is still underdeveloped.

The aim of this paper is to conduct research on why volunteers of generation Millennial sustain their voluntary work in one organization for more than a year. In order to build a solid theoretical understanding of the main research question, the researcher aims to answer what motivates people in general to engage in voluntary work and further on to sustain it? Further, what are the needs and expectations of Millennials to stay motivated at their workplace? Finally, which organizational factors can make Millennial volunteers motivated for longer than one year?

The current study will first elaborate on two main streams of literature: (1) volunteering and sustained volunteerism, further (2) Millennials' characteristics and their expectations towards the workplace. After reviewing existing literature, by the combination of a case study and the grounded theory approach, using empirical data the study aims to build theory on what organizational factors can retain Millennials at a voluntary organization. The study focuses on Millennials who are university students. The case study was conducted within the Amigos Foundation. As a result of the research, propositions will be constructed to have a deeper understanding of why Millennials sustain their voluntary work, additionally, avenues for future research and limitations will be discussed. 


\section{Theoretical background}

\section{Volunteering}

There are many different academic definitions for volunteering. According to Smith (1994), if helping others happens without remuneration, the action is called volunteering. Penner claims that "volunteerism involves long-term, planned, prosocial behaviours that benefit strangers, and usually occur in an organizational setting" (Penner, 2002, p. 448). Further, Timms, N. and Timms, R. (1982) claims that "a volunteer undertakes unpaid work, but (...) may be said to earn moral credit" (p. 209). Despite all different definitions, we can conclude that volunteering happens without any financial compensation (Smith, 1994) and it is done for others to benefit, not the one who conducts the voluntary work (Omoto, 2005).

\section{Millennials}

There are different names for the people who were born between 1982 and 1999 (e.g., GenY, nGen, GenMe or Millennials, (Twenge, 2010), in the current paper the researcher will use the terminology Millennials. Millennials are youngsters who are optimistic with civic duty, sociable, however, influenced by instant messaging and they get easily bored according to Bennett (2012). This generation has different values and expectations compared to other generations (Westerman and Yamamura, 2007). Twenge (2012) claims that Millennials are the least work centric generation compared to the elder ones and leisure values are more important for Millennials than for the other generations. Finally, according to Rai (2012), Millennials mainly learn, socialize and make friends at their workplace.

\section{Incentives for engaging in voluntary work}

The phenomenon for which people engage in voluntary activity without any financial compensation has become a popular topic among researchers in the past few decades. (Unger, 1991; Clary et al, 1998; Carpenter and Myers, 2010) According to these researchers there are many different motivations for someone to engage in a prosocial activity, such as family traditions, religiosity, altruism, recognition, positive image, making social contacts, improve skills, develop career, etc. To understand the incentives for volunteering, Clary et al (1998) developed the Volunteer Function Inventory (VFI) model with six potential functions served by volunteerism which are the following: (1) value expressive function; (2) serving a knowledge function; (3) social adjustive function; 
(4) career developing or utilitarian function; (5) protective or ego-defensive function; (6) enhancement function.

\section{Needs and expectations of Millennials towards the workplace}

Scholars mainly agree that Millennials have different expectations towards their workplace and they suggest managers to pay attention to this emerging question in order to be able to retain youngsters. (Broadbridge et al., 2007; Luscombe et al., 2013; Aruna and Anitha, 2015) But what are these needs and expectations, how can organizations motivate Millennials at the workplace? Broadbridge et al. (2007) suggests four different fields for understanding Millennials: (1) employment terms and conditions; (2) management approach and culture; (3) personal career development; (4) personal values.

Altogether, based on prior literature Millennials are characterized by the extreme need for flexibility, inclusive style of management and autonomy, they are highly interested in self- development and crave responsibility while they aim for work-life balance and contributing to society.

\section{Methods}

\section{Research design}

Since there is little research about the incentives for voluntary work among Millennials, this study takes an inductive approach and aims to combine the two fields: motivations for volunteering with the expectations and needs of Millennials at their workplace. This research is based on a real-time, single instrumental case study (Blumberg et al., 2005; Creswell, 2007). In this cross-sectional case study (Blumberg et al., 2005), the aim is to gain a complex and detailed understanding of the attitudes, reasons and motivation among Millennials to sustain their voluntary work in one organization by taking the grounded theory approach (Glaser and Strauss, 1999 [1967]). The area of the study was confined to a Hungarian charity organization, Amigos Foundation. Amigos has been operating since 2014, helping children suffering from chronic diseases. During the trying times spent in the hospitals, children tend to fall behind their school responsibilities and drift apart from their peers, both contributing to a lack of motivation. The Amigo volunteers encourage and motivate them on the road of recovery by teaching foreign languages in a playful manner. The organization operates in Budapest, Szeged, Debrecen, and Szombathely, but they aim to grow national, then international. Considering the fact that volunteers spend 20 months in the organization on average (Amigos Foundation, 2018), Amigos serves as a proper case to answer the research question: which organizational factors can make 
Millennial volunteers motivated for longer than one year. By the adaptation of a grounded theory approach, the research focuses on the individuals who currently do voluntary work in Amigos and aims to build theory for the retention of Millennials in charity organizations. Additionally, at this point the researcher would like to mention that the organization was founded by herself in 2014, therefore she has access to data and volunteers within the organization.

\section{Data collection}

The researcher uses two different approaches to data collection in order to have diverse and comprehensive knowledge and plenty of information about volunteers and the organization. In detail, 13 semi-structured interviews were conducted and access to archival data was obtained. To select participants for the interviews, first the diversity of the interviewees was needed. To guarantee this, a matrix of two dimensions was elaborated based on the Amigo Performance Document (internal document continuously updated by the Chief Happiness Officer of Amigos, 2018). The dimensions of this matrix were the following: active years in Amigos; performance between September 2017 and March 2018 in Amigos. Participants were university students who have been volunteering in Amigos for at least one year, belonging to the age group of 20 to 25 years. There were students who already have professional working experience (not summer student jobs) and also without any professional work experience.

Table 1: Overview of interviewee selection

\begin{tabular}{lccc}
\hline $\begin{array}{l}\text { Active years } \\
\text { Performance }\end{array}$ & Basic performance & $\begin{array}{c}\text { Outstanding } \\
\text { performance }\end{array}$ & $\begin{array}{c}\text { Extremely active } \\
\text { performance }\end{array}$ \\
\hline $1-1,5$ years & 3 & 2 & 2 \\
$2-2,5$ years & 1 & 2 & 1 \\
$3-4$ years & 1 & $\mathrm{n} / \mathrm{a}$ & 1 \\
\hline
\end{tabular}

Source: own compilation 


\section{Data analysis}

To analyze data, first, interviews were recorded and transcribed, later shared with the interviewees to secure the factual accuracy of the data. Based on the comments provided by interviewees, transcriptions were corrected, later the new version was used for data analysis.

In line with Strauss and Corbin (1998) and Gioia (2012) the researcher went through three coding stages to build theory. First, to identify initial data categories, in-vivo coding was used to capture interviewees' meanings, sensations about the organization. At this part, many initial categories emerged from data. Second, second-order coding was applied to identify patterns and relationships between concepts emerged from data. This part was considerably iterative, the list of categories continuously changed over time. Third, second-order codes were used to settle aggregate theoretical dimensions.

The main source of data analysis were the semi-structured interviews and archival data served as a basis of knowledge about the organization, processes and background information for the researcher. According to Creswell (2007), in qualitative research, validity of the research design is crucial, also for the sake acceptability in the quantitative world. To increase all the four quality criteria suggested by Lincoln and Guba (1985) credibility, transferability, dependability and confirmability - this paper used two strategies.

First, to increase credibility, the research material went through credibility checks by interview validation. Second, the researcher relied on peer-debriefing (Lincoln and Guba, 1985). During the research project, a former student played the 'devils' advocate', checked all the research materials, asked about the methods, findings and highlighted negative examples as it is recommended by Creswell (2007).

\section{Results}

Figure 1 serves as an orientation for data structure of the findings. Five dimensions emerged from the analysis, which will be reported descriptively, including representative quotes from the volunteers of Amigos Foundation.

The first question in this paper was: what motivates people in general to engage in voluntary work and further on to sustain it. Using theories of volunteerism, it was argued that according to the Volunteering Inventory Function, there are six functions served by volunteerism (Clary et al., 1998) and based on the Three Stage Model of Volunteers' 
Duration Service (Chacón et al, 2007), volunteerism can be sustained if a role identity develops.

The second question was about the needs and expectations of Millennials to stay motivated at their workplace. To answer this question theoretically, Broadbridge's framework was taken (2007) to understand Millennials and it was combined with many other streams of literature. Namely there are four fields that should be approached to understand Millennials motivation: (1) employment terms and conditions, (2) management approach and culture, (3) personal career development, (4) personal values.

\section{Figure 1: Data structure}

\begin{tabular}{|c|c|c|}
\hline First order concepts & Second-order themes & Aggregate dimensions \\
\hline $\begin{array}{l}\text { Volunteers believe that they do good thing for others and } \\
\text { they share this common goal. }\end{array}$ & (a) Noble common goal & \\
\hline $\begin{array}{l}\text { Volunteers describe how good is their work for the kids } \\
\text { and parents, further they like that others respect their } \\
\text { work }\end{array}$ & (b) Impact and recognition & $\begin{array}{l}\text { Everyday } \\
\text { experience of } \\
\text { doing good }\end{array}$ \\
\hline $\begin{array}{l}\text { Description of a unique feeling, outstanding experiences } \\
\text { and the sensation that being Amgo is part of their life. }\end{array}$ & (c) Lifestyle & \\
\hline $\begin{array}{l}\text { Description of an inclusive community, mentioning } \\
\text { fundamental trust toward a stranger who is an Amigo }\end{array}$ & (d) Easy integration & \\
\hline $\begin{array}{l}\text { Description of a friendly environment where everyone } \\
\text { has friends }\end{array}$ & (e) Friendships & $\begin{array}{l}\text { Strong } \\
\text { community }\end{array}$ \\
\hline $\begin{array}{l}\text { References to a good company, strong bonds and } \\
\text { common values }\end{array}$ & (f) Bonding and shared values & \\
\hline Description of a well-built and well-functioning system & $\begin{array}{c}\text { (g) Straightforward organizational } \\
\text { structure }\end{array}$ & \\
\hline $\begin{array}{l}\text { Volunteers explaining how good is the length of the } \\
\text { activity and the flexibility }\end{array}$ & (h) Structure adjusted to lifestyle & \\
\hline $\begin{array}{l}\text { Volunteers claiming that everyone is equally important, } \\
\text { even managers are equal to volunteers, description of no } \\
\text { hierarchy, managers are not leaders but helpers of the } \\
\text { volunteers }\end{array}$ & (i) Flat organization & \\
\hline $\begin{array}{l}\text { References to "leaders are interested in my opinion", } \\
\text { description of a common, democratic and transparent } \\
\text { decision-making process }\end{array}$ & (j) Inclusive approach & \\
\hline $\begin{array}{l}\text { Volunteer belief of developing a lot in terms a social } \\
\text { skills, personality, reference to get opportunities for } \\
\text { development }\end{array}$ & (k) Development of social skills & \\
\hline $\begin{array}{l}\text { References to "I can try myself", description of the } \\
\text { development and high motivation related to supporting } \\
\text { tasks }\end{array}$ & $\begin{array}{l}\text { (1) Development of professional } \\
\text { skills }\end{array}$ & $\begin{array}{l}\text { personal } \\
\text { developmen }\end{array}$ \\
\hline $\begin{array}{l}\text { Description of big enough responsibility given to the } \\
\text { volunteers and autonomy, opportunity for self- } \\
\text { management }\end{array}$ & (m) Mutual trust & \\
\hline
\end{tabular}

Source: own compilation 
Yet, the current research, combining the two above mentioned areas with the empirical data, found two main areas to focus on in the retention of Millennial volunteers from an organizational perspective. First, for Millennial volunteers, organizational factors seem to be outstandingly important. They care about the organization in which they contribute to society by volunteering, they aim for a well-functioning framework for daily operations combined with flexibility. As reported by interviewees they are motivated to sustain their voluntary work by a flat organizational structure where they feel equal, they seek getting involved in organizational processes and decision making. Second, empirical data demonstrated that for Millennial volunteers there is an important factor in volunteering "What can I get?". They have a strong need for positive feedback and recognition from the environment. One of the most important factors for them is the community. Furthermore, they seek professional development which is not certainly connected to the main voluntary task, they like it when opportunities are given for trying themselves in other roles as well. Additionally, conforming to empirical data, autonomy, responsibility and mutual trust are essential for keeping millennials motivated for longer than one year.

Figure 2: What organizational factors contribute to Millennials' retention at a voluntary place?

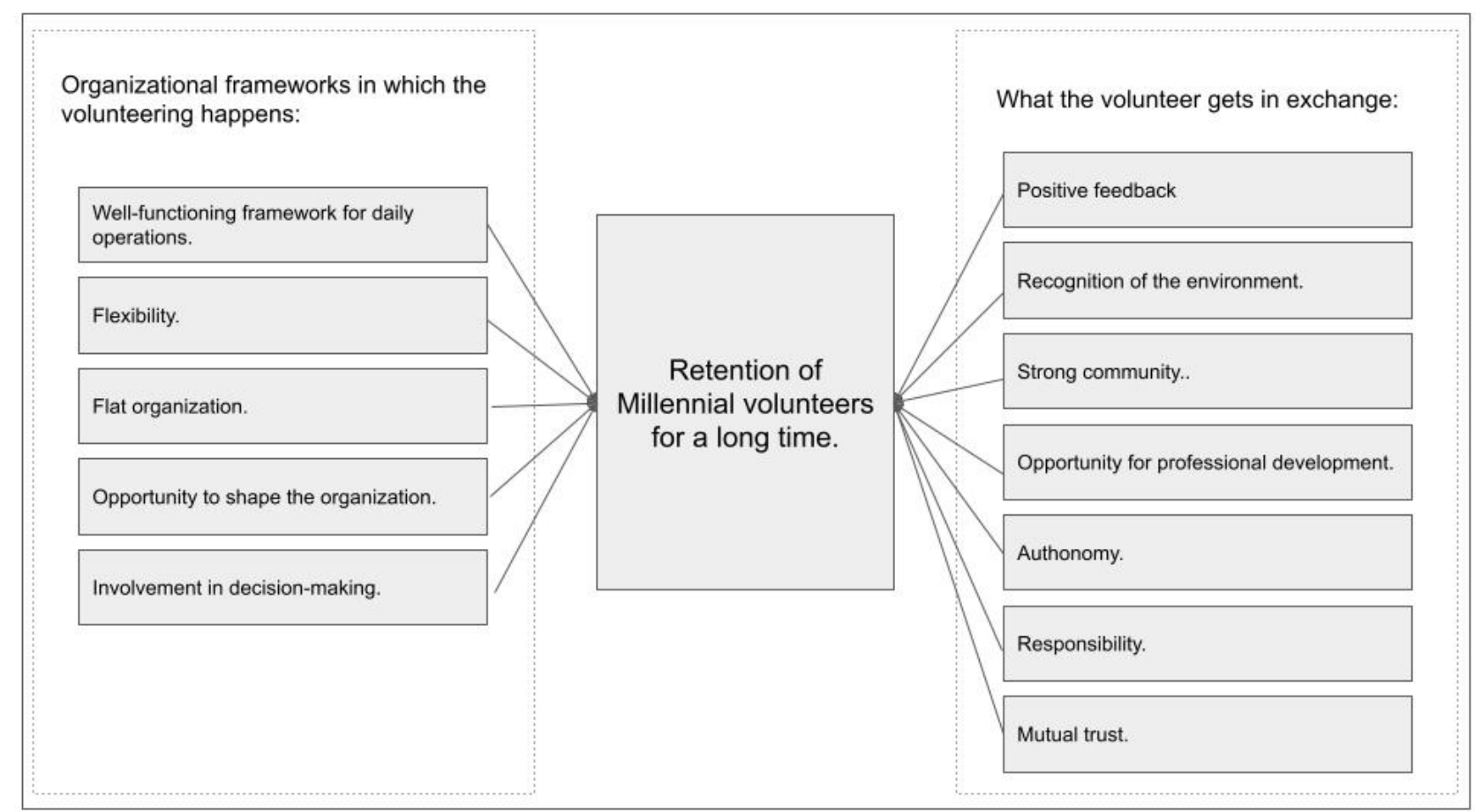

Source: own compilation 


\section{Discussion and recommendations}

\section{Implications for theory}

Twenge (2010) reports that regarding altruistic and intrinsic values there are no differences between generations. If we accept this claim, we can reach two different conclusions. First, if there are no generational differences, we do not have to manage Millennials differently in charity organizations where altruistic values are the main motivation for everyone. Or we can suggest, that if they have the same altruistic and intrinsic values as other generations, we should focus on other aspects that organizations can control to retain Millennials successfully because altruism is not motivating enough in itself.

The findings suggest that Millennials are a conscious generation, they seek many organizational factors to be realized, therefore only a noble goal is not enough for retaining them. It is suggested that organizations should focus more on what they can provide for Millennial volunteers (e.g., community, opportunities for personal development), rather than only take care of the mission of the organization. Previous research on volunteerism has demonstrated that career enhancement, knowledge and skill improvement are two factors served by volunteerism (Clary et al., 1998), however the current study suggests that for Millennials it might be more important than we assume.

Various scholars investigated the development of role identity (Grube and Piliavin, 2000; Penner, 2002; Chacón et al., 2007) and the current study also underpins the importance of it among volunteers. However, the results of this study show that for Millennials one of the most important reasons for sustaining their voluntary work is the community, which has not been emphasized in previous research on volunteerism, but in the literature stream of Millennials. This current study suggests that building a strong community is positively related to Millennials' retention in a voluntary organization.

Further, as Hartenian (2007) suggests, there are two different types of volunteering: direct service and indirect support. As findings show, some volunteers are motivated by the supporting tasks rather than the original mission over time. This implies that the sustenance of voluntary service might be related to the involvement of Millennials in the indirect support, not only the direct service of the organization. However, the degree of involvement in the two different types of volunteering remains a question for future research. 


\section{Implications for managerial practice}

The research addresses an important phenomenon, since the number of volunteers is growing, but there is little knowledge on how to motivate the upcoming generations for sustaining their voluntary work. Furthermore, due to the law on 50 hours of obligatory community service during secondary school years, as the criterion of successful graduation, all of the secondary school students get involved in voluntary work, but organizations might not be prepared for retaining these voluntary workers.

The research also suggested some practical implications for managers. As we have seen in the findings section, non- profit organizations should focus more on the organizational factor and on what they can provide for Millennial volunteers and even younger generations. One practical suggestion is the involvement in background tasks as engaging in the daily operations of the organization might increase commitment towards the organization. Empirical data showed that Millennials liked it when they could try out themselves in different roles and they were motivated by supporting tasks as well, sometimes even more than by the mission-related task. Another practical implication is the community building. As interviewees explained, at a workplace they might give up their need for community events and programmes, but at a charity place they have a stronger need for the sense of belonging somewhere, making friends and enjoying teamwork. Therefore, managers should focus on community building and providing opportunity for volunteers to get closer to each other.

\section{Limitations and directions for future research}

The current study focuses on Millennial volunteers, especially volunteers of Amigos Foundation, in Hungary, who are all university students. This implies that the generalizability of the study might be one of the limitations. Additionally, the research was conducted on a small sample size, with 13 interviewees. At this point, the researcher would like to inform the reader that Amigos Foundation was founded by the author of this paper in 2014, which means that on one hand there was a great amount of available information for the researcher but on the other hand, the avoidance of biases was of high priority. Despite all the strategies used for increasing quality criteria (Lincoln and Guba, 1985) (e.g., credibility checks by interview validation, telling the interviewees that the current research is not directly linked to Amigos) confirmability still might be lower since the researcher is the founder of the organization which can cause biases during the interviews and also data analysis. To eliminate biases of the author, peer debriefing (Creswell, 2007) was used. 
Future research could be conducted on multiple cases, not only the case of Amigos Foundation, and compare different organizations, motivations of Millennials of different levels of education, not only university students, even in organizations operating in different sectors to get a more generalizable result. Another stream of future research is suggested by the author: the relationship between stewardship or servant leadership and volunteerism. However, this study does not focus on stewardship or servant leadership (Lussier and Achua, 2010) many characteristics of stewardship/servant leadership might be identified in the empirical data (e.g., equality assumption, helping others to discover their inner spirit, earning and keeping others' trust, etc..). The connection between stewardship/servant leadership and Millennial volunteers' motivation to remain in an organization remains still under researched however, this approach towards leadership might contribute significantly to Millennials' retention in voluntary organizations.

All in all, this paper analyses prior literature on volunteerism and Millennials' characteristics, further gives answer to the question which organizational factors can make Millennial volunteers motivated for longer than one year. The research was conducted by taking a combination of case-study and grounded theory approach to build new theory. Additionally, the paper indicates avenues for possible future research and limitations of the current study. All with the aim of helping the development of the non-profit sector of Hungary and even other countries with cultural and societal structures similar to the Hungarian one.

\section{References}

Amigo performance [XLS]. (2018). Budapest: Amigos a gyerekekért Alapítvány.

Aruna, M., \& Anitha, J. (2015). Employee retention enablers: Generation Y employees. SCMS Journal of Indian Management, 12(3), 94.

Aydinli, A., Bender, M., Chasiotis, A., Van de Vijver, F. J., Cemalcilar, Z., Chong, A., \& Yue, X. (2015). A cross-cultural study of explicit and implicit motivation for long-term volunteering. Nonprofit and Voluntary Sector Quarterly,45(2), 375-396. https://doi.org/10.1177/0899764015583314

Aydinli, A., Bender, M., Chasiotis, A., Van de Vijver, F. J., Cemalcilar, Z., Chong, A., \& Yue, X. (2015). A cross-cultural study of explicit and implicit motivation for long-term volunteering. Nonprofit and Voluntary Sector Quarterly,45(2), 375-396. https://doi.org/10.1177/0899764015583314

Bennett, J., Pitt, M., \& Price, S. (2012). Understanding the impact of generational issues in the workplace. Facilities,30(7/8), 278-288. https://doi.org/10.1108/02632771211220086

Broadbridge, A. M., Maxwell, G. A., \& Ogden, S. M. (2007). 13_2_30: Experiences, perceptions and expectations of retail employment for generation y. Career Development International, 12(6), 523-544. https://doi.org/10.1108/13620430710822001 
Broadbridge, A. M., Maxwell, G. A., \& Ogden, S. M. (2007). Students' views of retail employment - key findings from generation ys. International Journal of Retail \& Distribution Management, 35(12), 982-992. https://doi.org/10.1108/09590550710835210

Carpenter, J., \& Myers, C. K. (2010). Why volunteer? Evidence on the role of altruism, image, and incentives. Journal of Public Economics, 94(11-12), 911-920. https://doi.org/10.1016/j.jpubeco.2010.07.007

Chacón, F., Vecina, M. L., \& Dávila, M. C. (2007). THE three-stage model OF VOLUNTEERS' duration of service. Social Behavior and Personality: An International Journal, 35(5), 627-642. https://doi.org/10.2224/sbp.2007.35.5.627

Charng, H., Piliavin, J. A., \& Callero, P. L. (1988). Role identity and Reasoned action in the prediction of repeated behavior. Social Psychology Quarterly, 51(4), 303. https://doi.org/10.2307/2786758

Clary, E. G., Snyder, M., Ridge, R. D., Copeland, J., Stukas, A. A., Haugen, J., \& Miene, P. (1998). Understanding and assessing the motivations of volunteers: A functional approach. Journal of Personality and Social Psychology,74(6), 1516-1530. https://doi.org/10.1037/0022-3514.74.6.1516

Creswell, J. W. (2007). Qualitative inquiry and research design: Choosing among five traditions. Thousand Oaks, CA: Sage.

Creswell, J. W., \& Miller, D. L. (2000). Determining validity in qualitative inquiry. Theory Into Practice, 39(3), 124-130. https://doi.org/10.1207/s15430421tip3903_2

Cooper, D. R., Schindler, P. S., \& Sun, J. (2006). Business research methods (Vol. 9, pp. 1-744). New York: Mcgraw-hill.

Founding document [PDF]. (2016). Veszprém: Amigos a gyerekekért Alapítvány.

Geiser, C., Okun, M. A., \& Grano, C. (2014). Who is motivated to volunteer? A latent profile analysis linking volunteer motivation to frequency of volunteering. Psychological Test and Assessment Modeling, 56(1), 3.

Gioia, D. A., Corley, K. G., \& Hamilton, A. L. (2012). Seeking qualitative rigor in inductive research. Organizational Research Methods, 16(1), 15-31. https://doi.org/10.1177/1094428112452151

Glaser, B. G. (1999). The future of grounded theory. Qualitative Health Research, 9(6), 836-845. https://doi.org/10.1177/104973299129122199

Grube, J. A., \& Piliavin, J. A. (2000). Role identity, organizational experiences, and volunteer performance. Personality and Social Psychology Bulletin, 26(9), 1108-1119. https://doi.org/10.1177/01461672002611007

Hartenian, L. S. (2007). Nonprofit agency dependence on direct service and indirect support volunteers: An empirical investigation. Nonprofit Management and Leadership, 17(3), 319-334. https://doi.org/10.1002/nml.152

Lincoln, Y. S., Guba, E. G., \& Pilotta, J. J. (1985). Naturalistic inquiry. International Journal of Intercultural Relations, 9(4), 438-439. https://doi.org/10.1016/0147-1767(85)90062-8 
Luscombe, J., Lewis, I., \& Biggs, H. C. (2013). Essential elements for recruitment and retention: Generation y. Education + Training, 55(3), 272-290.

https://doi.org/10.1108/00400911311309323

Lussier, R. N., \& Achua, C. F. (2015). Leadership: Theory, application, \& skill development. Nelson Education.

Omoto, A. M. (2014). Processes of Community Change and Social Action. Hoboken: Taylor and Francis.

Penner, L. A. (2002). Dispositional and ORGANIZATIONAL influences on Sustained Volunteerism: An Interactionist Perspective. Journal of Social Issues, 58(3), 447-467. https://doi.org/10.1111/1540-4560.00270

Rai, S. (2012). Engaging young Employees (Gen y) in a social Media dominated world - review and retrospection. Procedia - Social and Behavioral Sciences, 37, 257-266. https://doi.org/10.1016/j.sbspro.2012.03.292

Shin, S., \& Kleiner, B. H. (2003). How to manage unpaid volunteers in organisations. Management Research News,26(2/3/4), 63-71. https://doi.org/10.1108/01409170310784005

Smith, D. H. (1994). Determinants of voluntary association participation and volunteering: A literature review. Nonprofit and Voluntary Sector Quarterly, 23(3), 243-263. https://doi.org/10.1177/089976409402300305

Smith, K. T. (2010). Work-life balance perspectives of marketing professionals in generation y. Services Marketing Quarterly, 31(4), 434-447. https://doi.org/10.1080/15332969.2010.510724

Strauss, A., \& Corbin, J. (1990). Basics of qualitative research. Sage publications.

Timms, P. N. (2013). Dictionary of social welfare. https://doi.org/10.4324/9781315029696

Twenge, J. M. (2010). A review of the empirical evidence on generational differences in work attitudes. Journal of Business and Psychology, 25(2), 201-210. https://doi.org/10.1007/s10869-010-9165-6

Unger, L. S. (1991). Altruism as a motivation to volunteer. Journal of Economic Psychology, 12(1), 71-100. https://doi.org/10.1016/0167-4870(91)90044-t 


\title{
Thin Ice: Teasing Play as a Network-Forming Force in Organizations
}

\author{
RITA TÓTH* \\ *Corvinus University of Budapest, Institute of Management; \\ toth.rita@uni-corvinus.hu
}

DOI: $10.14267 / 978-963-503-867-1 \_09$

\begin{abstract}
Play is a deeply human constitutive activity of organizational life, which may manifest in several distinct processes. In the present study, the author compasses a particular culturally relative form of play, namely teasing in the workplace setting. Conducting a meta-synthesis of adjacent streams of literature, the author reframes the concept of teasing and inspects it through the analytical lens of play. The research unfolds how teasing behaviour may form an invisible meta-network in organizations, which may fundamentally affect group and organizational dynamics.
\end{abstract}

Keywords: play at work, teasing, serious play, network of play

Funding: The present publication is the outcome of the project „From Talent to Young Researcher project aimed at activities supporting the research career model in higher education," identifier EFOP-3.6.3-VEKOP-16-2017-00007 co-supported by the European Union, Hungary, and the European Social Fund. 


\section{Introduction}

Play, as a core process of organizing, is getting increasing attention among organization scholars and practitioners lately, as it is studied as an alternative form of knowledge production, knowledge-sharing, and learning. In the workplace context, scholars have already revealed how play enhances creativity (Mainemelis \& Ronson, 2006), makes decision-making more flexible and helps relating to unknown future (Andersen \& Pors, 2014, 2015), develops norms and ethical orientation (Statler et al, 2009) and supports the well-being of the employees (Costea et al., 2005). Still, workplace play is blurred with gamification efforts, playful design or top-down management practices neglecting the fact that what is said to be a game or a play activity is not always the same as what is perceived as play for real from the participants' perspectives. As part of a broader research in 2020, which aimed to shed light on the employee's perceptions and recognitions of workplace play, participants were asked to complete the following unfinished sentence: „The best game/type of play at my workplace is...." Amongst others, the activity of teasing has emerged significantly, labelled as play. These results suggested having a close look at teasing in the organizational settings and examine the phenomenon through the lens of play.

Reframing the already ambiguously playful phenomenon of teasing as play, may lead us towards new theoretical knowledge and practical implications. Research that unfolds the characteristics of teasing and play relationships in organizations is scarce. Hence, it is worth asking the question as to how can we imagine organizations as a set of play processes and how can we understand teasing within this setting? In this conceptual study, I look for answers for this question, and I build on interdisciplinary knowledge about teasing and play theories. The aim of the research is to synthesize existing knowledge and come to a new awareness of teasing play as an underlying effect of organizational dynamics. As for my main argumentation I propose, that teasing play is a call for meta-level relationships and gives rise to the emergence of a social meta-network in organizations, which has a significant impact on group and organizational dynamics.

\section{Methodology}

Noting that both play and teasing are understudied and under-published fields in management studies, I have carried out a meta-synthesis exploring also adjacent streams of literature. Meta-synthesis is an interpretative method to explore selected qualitative research (Thorne et al., 2004; Major \& Savin-Binden, 2011). The present meta-synthesis pertains to the constructionist category according to the typology of Major and SavinBaden (2011), as the analysis and the synthesis of data was followed by interpretation 
and construction of new meanings of existing qualitative evidence. Towards this end, I start with the review of the concept of play, as it has been understood in the literature of management studies, and continue the review of knowledge about teasing. Throughout a theory-building exercise, I conceptualize teasing as a culturally relative form of play in organizations. I argue that the interaction of teasing play is the trigger, which calls certain relations into existence and further determine their quality as positive, negative or play.

\section{Theoretical findings}

\section{Play at work. Two sides of the same coin}

Even though developmental psychology traces play until the age of adolescence, there is evidence, that play is peculiar to adulthood as well. Hence, it can be considered as a lifelong fundamental characteristic of human being, constantly influencing our milieu even in organizational settings. Some researchers argue that play is the most understudied and least understood form of organizational behaviour (Mainemelis \& Ronson, 2006). The forerunner theoretical basis of the ongoing "ludicization" process of Western society, in the course of which social, cultural and economic life is becoming growingly play-orientated (Thibault \& Heljakka, 2018), comprises the theory of an entirely play-based culture (Huizinga, 1944), the assumption of the everyday role-playing of humans (Goffmann, 2008) and the anthropological information about rites and ritual (Turner, 1982). Although it is easily recognizable by anyone as a human activity, the boundaries of play remain unclear.

In the workplace context, there is no consensus-based scientific definition neither of play nor of games. General play theories emphasise the autotelic, joyful nature of play and refer to the spatial and temporal characteristics, according to which play usually happens independently from and parallel to real time and owns its own virtual space in a rather spiritual sense. Regarding the immature concept of organizational play, it is a common agreement that play is a multifaceted metacommunicative activity (Bateson, 1987) that is carried out for the purpose of amusement and fun, approached with an enthusiastic and in-the-moment attitude, and it is highly interactive (VanFleet \& Feeney, 2015). Play can be as much as the mode of learning or knowing as the condition of emotional survival (Sutton-Smith, 2008). However, there are still major differences in the conceptualization of workplace play regarding the paradigm lens through which it is studied.

From a functionalist perspective, play in the organizational context is seen as an instrument, which may be an activity, a process, a trait or a cultural feature originating from work or non-work-related antecedents holding a number of roles depending on its 
character and resulting in various outcomes on individual, team and organisational level (Petelicz et al. 2018). The approach constitutes management techniques and developmental practices as well under the emerging umbrella terms of serious play (Statler et al., 2009) and serious games (Mayer et al., 2016). On one hand, serious games make up the digital and traditional games that have been created to develop a relevant workplace competence (Mayer et al., 2016). On the other hand, the relevance of serious play has been approached from the stance of leadership development and organizational development in terms of utilizing the imaginative nature of playful tasks to construct reallife solutions in the context of strategic thinking, innovation or moral development (Statler et al., 2011). Statler et al. (2011) reframed serious play as practice of paradox, and argued that the paradox of intentionality, namely that play, which is carried out for play itself, can serve other ends, may support the stretching of the boundaries of people.

However, there is more to play than just considering it as a tool for management and development. Play goes beyond managing due to its inherently ambiguous and open-ended nature. Considering philosophical thoughts within the frame of an interdisciplinary approach, we find that play refers to the ontology of the entire human existence beyond matters of childhood. In this sense, playfulness is a fundamental characteristic of organizations, which reframes our understanding of workplace processes, meaning thatall kinds of activities can be perceived and experienced as play (Roy, 1959; Salovaara \& Statler 2018). From the reverse side, all kinds of activities can be recognized as play, based on subjective interpretation. Play, therefore, permeates organizational life and gives an intrinsically motivated, joyful nature for the activities, from the perspective of the actors.

Andersen and Pors (2014) argue that play is the possibility for organizations to reach out for presently imaginable futures, when implicated into management practises. Their propositions are based on empirical research on the comparison of temporalities of play and decision-making. Hence, decisions bring uncertainty of the future to the present, and conversely play brings the present into the future, creating a surplus of possibilities, thus, expanding contingency while taking advantage of it (Andersen \& Pors, 2014). Through this lens, the role of play is to enhance the transformative capability of an organization by preparing for continual change and development. By making available opportunities visible through play, a "shadow organization" evolves (Andersen, 2009) and reality doubles. In this sense an organization can be considered as a set of constantly negotiated social constructs (Schwandt, 2000), which can be created into meaningful existence by play (Andersen, 2009). 


\section{Teasing}

To better understand the phenomenon, there is an ongoing research tradition, which frames teasing with the help of Erving Goffman's concept of face (1955). Researchers engaged towards this approach consider teasing as a form of context-dependent strategic interaction, which varies along the participants face-concerns (Haugh, 2010; Keltner et al., 2001) and occur to renegotiate conflicts and regulate norm deviations (Keltner et al., 2001). Such framing gave rise to an unlimited number of hypothesises and studied the correlation between social distance, social power, and teasing-related variables such as aggression, likelihood, or the quantity of playful markers (Keltner et al., 1998, 2001). However, lacking a consensus-based definition and appropriate methodology, these studies remained unproved assumptions.

A related line of argument presents teasing as a form of conversational joking, serving as a means to social regulation (Fine \& Saucey, 2005), individual, social and relational identity construction and display (Boxer \& Cortez-Condé, 1997; Schnurr, 2009), workplace initiation (Mawritz et al., 2020) and emotional attunement (Pouthier, 2017). Although researchers, who studied humour and joking in the organizational context, have already shown how these activities may be indicators of paradox and ambiguity (Hatch, 1993) or resistance (Westwood, 2013), there has been little attention paid on what the particular teasing habits would tell about organizations and how this knowledge could be implemented into organization theory or organizing practice.

In the present paper, I build my conception on the definition of Keltner et al. (2001), which distinguishes teasing from other relating activities and clarifies its conceptual place in humorous settings. Teasing may seem like disgraceful mocking on the surface, therefore, it is easily related to hazing and bullying instead of play. After reviewing and synthesizing more than 50 papers about teasing, Keltner et al. (2001) have created a definition for teasing, which overcomes the blind spots of its antecedents. With their words, a tease is an "intentional provocation accompanied by playful off-record markers that together comment on something relevant to the target" (Keltner et al., 2001, 234 p.). This definition highlights the intentional nature of the provocation, which is not labelled neither as inherently kind-hearted nor malignant. In this sense, teasing instead is inherently ambiguous and its outcomes depend on the interplay between the parties including the response given to a tease (Alberts, 1992). Responses, however, show correlation with the perception of the intentionality of teasing, which is mediated by the feeling of closeness (Gorman \& Jordan, 2015). Keltner's definition clearly distinguishes teasing from other associated aggressive activities (e.g., bullying) which do not include playful off-record markers. 


\section{Teasing play in organizations: A theory building exercise}

What if we imagine the inherently playful teasing as it was play? What impact would it have on organizations? Invoking the teasing continuum of Boxer and Cortez-Condé (1997), which ranges from bonding to nipping to biting, we should note the underlying play theory of Bateson (1987) who argued that "a playful nip denotes a bite, but it does not denote what would be denoted by a bite" (1987, 18 p.). He emphasized, that as in the animal world, there is a safe space for practising fighting, when they engage in play and there is such a specific virtual place for people who play as well. In this sense, a tease is a kind of initiation that has transformative ability by shocking or surprising the participant, thus arming him or her with resilience and vigilance for the future, theoretically serving as the condition for emotional survival (Sutton-Smith, 2008). Play creates a "magic circle" as its own space, where its own specific rules obtain (Huizinga, 2016). The magic circle is a virtual world in a spiritual sense, but it can be created also in a digital environment. This "magic circle" or "shadow organization", which is the doubling of the real world, can be understood as the liminal space in terms of rituals, where transformation happens.

Second, as play is considered to be an activity, complemented by a meta-communication process, which constantly revises whether the activity was play (Bateson, 1987), a tease can be considered as an upbeat, an invitation to expand the relationship onto a higher, more intimate level (Haugh \& Pillet-Shore, 2017). The invitation can be accepted or declined as well, which means, that through teasing play, a social meta-network emerges in organizations, which is beyond formal control. Tie as the fundamental unit of social network analysis can be distinguished along the typology of dyadic relations as shown in Table 1. (Borgatti et al., 2009). In the case of the teasing play network, relational distinctions can be assumed as follows. 
Figure 1: Dyadic relations of the teasing play network

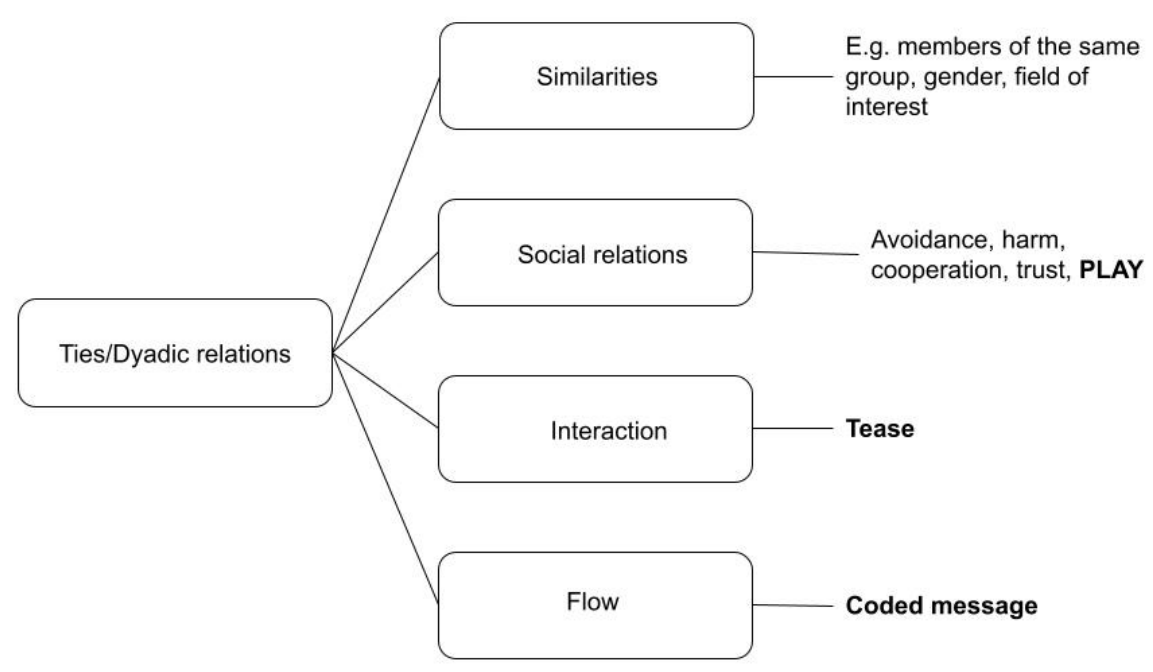

Source: adapted from Borgatti et al. (2009)

Building on the dyadic relations model, a tease can be considered as an interaction, which may serve as the trigger, or initiative of the new level of the relationship. This new level can be described either as positive or as negative as the result of the answer given to the tease. More clearly, during the interaction of teasing, a coded message flows from the teaser to the target and the coding of the message determines the further social quality of the tie. In this sense, a tease may result in distrust or avoidance which count as negative relations, and it can also end up in a trustful or a cooperative relation. Here I add the play relation as a third, paradox possibility, standing beyond positive or negative judgement, still characterised by a transformative quality.

Within this meta-network, a special focus should be given to the interaction of the teasing play as it forms the social relation as a one-time interaction and furthermore constantly reforms the relation when conducted regularly. If the tease triggers a play relation, the characteristics of the tie will depend on which rhetoric of play is dominating it. There are seven overlapping rhetorics of play identified as power, self, identity, progress, fate, imaginary and frivolity, which may determine how we see and study the phenomenon, and also the meaning or function we appropriate to it (Sutton-Smith, 1997). In other words, relationships of this meta-network may be a means to distinct ends, which are associated with a particular rhetoric. In this regard a teasing relationship can head 
towards creative outputs or norm regulation as well as counter-productive status maintenance.

All things considered if we build on the seminal theory of Huizinga (2016), who put the whole human culture on a play basis, we might be empowered to "read" the play behaviour including teasing patterns of organizations to understand organizational culture in a given setting. Geertz's idea (2017) about social play being a projective platform from which power relations can be read, suggests that the inspection of play might be a supportive ground for organizational development (OD) practices, as well as critical management studies.

\section{Conclusion and implication for further research}

I briefly summarized existing knowledge and theories about teasing and play in a workplace context and introduced my conceptualization of teasing as a particular kind of workplace play. By doing so, I came to a new awareness of teasing play as a networkforming force in organizations, which can be analysed in terms of play, constituting paradox intentionality, liminal transformations and underlying play rhetoric, which may fundamentally affect organizational dynamics.

My contribution to the existing scientific literature is twofold. On one hand, by reframing teasing as play I opened new doors for further understanding complex social phenomena in group and organization behaviour. On the other hand, by revealing how teasing behaviour may form a meta-level network, my study may serve as a point of departure when advancing knowledge on how certain ties come into existence while others disappear in organizations.

A limitation of the research is that the conduct of this meta-synthesis was influenced by my own experience and interest in the topic of teasing. Another limitation is concerning the methodology, as there are a number of high-quality studies excluded from this investigation, even though quality and theoretical saturation is more important than numbers for this kind of meta-synthesis. However, bearing these limitations in mind, I argue that my conceptual study could add something to the better understanding of teasing play at work and provided some initiatives for further research. Given that the domains of teasing and play represent a relatively under-explored field of research, there are many new and exciting questions, which would be important to pursue regarding the themes along which organizational play can be analysed, and methodological concerns for identifying teasing networks in organizations. 


\section{References}

Alberts, J. K. (1992). An Inferential/Strategic Explanation for the Social Organisation of Teases. Journal of Language and Social Psychology, 11(3), 153-177. https://doi.org/10.1177/0261927x92113003

Andersen, N. A, \& Pors, J. G. (2014). Playful membership: Embracing an unknown future. Management \&3 Organizational History, 9(2), 166-183. https://doi.org/10.1080/17449359.2014.891796

Andersen, N. A. (2009). Power at play: The relationships between play, work and governance. Palgrave Macmillan.

Bateson, G. (1987). Steps to an ecology of mind. Northvale, NJ: Jason Aronson.

Borgatti, S. P., Mehra, A., Brass, D. J., \& Labianca, G. (2009). Network Analysis in the Social Sciences. Science, 323(5916), 892-895. https://doi.org/10.1126/science.1165821

Fine, G. A., \& Soucey, M. D. (2005). Joking cultures: Humor themes as social regulation in group life. Humor - International Journal of Humor Research, 18(1), 1-22. https://doi.org/10.1515/humr.2005.18.1.1

Geertz, C. (2017). The interpretation of cultures. London: Basic Books. (Original work published 1971)

Goffman, E. (1955). On face work: An analysis of ritual elements in social interaction. Psychiatry, 18(8), 213-31.

Goffman, E. (2008). The presentation of self in everyday life. New York: Anchor Books. (Original work published 1959)

Gorman, G., \& Jordan, C. H. (2015). "I know you're kidding": Relationship closeness enhances positive perceptions of teasing. Personal Relationships, 22(2), 173-187. https://doi.org/10.1111/pere.12071

Hatch, M. J., \& Erhlich, S. B. (1993). Spontaneous Humour as an Indicator of Paradox and Ambiguity in Organizations. Organization Studies, 14(4), 505-526. https://doi.org/10.1177/017084069301400403

Haugh, M. (2010). Jocular mockery, (dis)affiliation, and face. Journal of Pragmatics, 42(8), 2106-2119. https://doi.org/10.1016/j.pragma.2009.12.018

Haugh, M., \& Pillet-Shore, D. (2017). Getting to know you: Teasing as an invitation to intimacy in initial interactions. Discourse Studies, 20(2), 246-269. https://doi.org/10.1177/1461445617734936

Huizinga, J. (1944). Homo ludens: A study of the play-element in culture. Kettering, OH: Angelico Press.

Keltner, D., Capps, L., Kring, A. M., Young, R. C., \& Heerey, E. A. (2001). Just teasing: A conceptual analysis and empirical review. Psychological Bulletin, 127(2), 229-248. https://doi.org/10.1037/0033-2909.127.2.229

Keltner, D., Young, R. C., Heerey, E. A., Oemig, C., \& Monarch, N. D. (1998). Teasing in hierarchical and intimate relations. Journal of Personality and Social Psychology, 75(5), 1231-1247. https://doi.org/10.1037/0022-3514.75.5.1231 
Mainemelis, C., \& Ronson, S. (2006). Ideas are Born in Fields of Play: Towards a Theory of Play and Creativity in Organizational Settings. Research in Organizational Behavior, 27, 81-131. https://doi.org/10.1016/s0191-3085(06)27003-5

Major, C. H., \& Savin-Baden, M. (2011). Integration of qualitative evidence: Towards construction of academic knowledge in social science and professional fields. Qualitative Research, 11(6), 645-663. https://doi.org/10.1177/1468794111413367

Mawritz, M. B., Capitano, J., Greenbaum, R. L., Bonner, J. M., \& Kim, J. (2020). Development and validation of the workplace hazing scale. Human Relations, 001872672095705. https://doi.org/10.1177/0018726720957058

Petelczyc, C. A., Capezio, A., Wang, L., Restubog, S. L., \& Aquino, K. (2018). Play at Work: An Integrative Review and Agenda for Future Research. Journal of Management, 44(1), 161-190. https://doi.org/10.1177/0149206317731519

Pouthier, V. (2017). Griping and Joking as Identification Rituals and Tools for Engagement in Cross-Boundary Team Meetings. Organization Studies, 38(6), 753-774. https://doi.org/10.1177/0170840616685358

Roy, D. (1959). "Banana Time": Job Satisfaction and Informal Interaction. Human Organization, 18(4), 158-168. https://doi.org/10.17730/humo.18.4.07j88hr1p4074605

Schnurr, S. (2009). Constructing leader identities through teasing at work. Journal of Pragmatics, 41(6), 1125-1138. https://doi.org/10.1016/j.pragma.2008.10.002

Statler, M., Heracleous, L., \& Jacobs, C. D. (2011). Serious Play as a Practice of Paradox. The Journal of Applied Behavioral Science, 47(2), 236-256. https://doi.org/10.1177/0021886311398453

Statler, M., Roos, J., \& Victor, B. (2009). Ain't Misbehavin': Taking Play Seriously in Organizations. Journal of Change Management, 9(1), 87-107. https://doi.org/10.1080/14697010902727252

Sutton-Smith B (2008) Play theory: A personal journey and new thoughts. American Journal of Play, 1:80-123.

Sutton-Smith, B. (1997). The ambiguity of play. Cambridge, MA: Harvard University Press.

Thorne, S., Jensen, L., Kearney, M. H., Noblit, G., \& Sandelowski, M. (2004). Qualitative Metasynthesis: Reflections on Methodological Orientation and Ideological Agenda. Qualitative Health Research, 14(10), 1342-1365. https://doi.org/10.1177/1049732304269888

Turner, V. W. (1982). From ritual to theatre: The human seriousness of play. New York: PAJ. Westwood, R. I., \& Johnston, A. (2013). Humor in organization: From function to resistance. Humor, 26(2). https://doi.org/10.1515/humor-2013-0024 


\title{
Comparative Analysis of Change Management Models Based on an Exploratory Literature Review
}

\author{
ANARA BEKMUKHAMBETOVA* \\ *Corvinus University of Budapest, Doctoral School of Business and Management; \\ anara.bekmukhambetova@gmail.com
}

DOI: $10.14267 / 978-963-503-867-1 \_10$

\begin{abstract}
Nowadays, a lot of companies are faced with the urgency of change in their daily operations. This is especially relevant in modern business development conditions when constant changes are considered critical for a company to adapt to market requirements and the global economic situation. The paper presents the audit of the most famous change management models. Change management is an endless cycle, and it requires a sound vision, plan, time, aptitudes, inspiration, monetary and automatic endeavors to execute the change. Successful change management is a venture and contributes to a hierarchical turn of events. There are a few models of change management available and choosing the right change management model is vital for leading or guiding productive and smooth transitions. The main goal of this paper is to describe the main differences between the well-known change management models by reviewing the relevant literature. The analysis led to the conclusion that it is impossible to pick up an optimal approach to change management. Every approach to change management attracts attention to various aspects of this problem; however, they do not exclude but complement each other.
\end{abstract}

Keywords: change management, change models, organizational change.

Funding: the author did not receive any grant or institutional support in relation to the study's preparation. 


\section{Introduction}

The term 'Change Management' is explained in the literature by different authors (e.g., Moran and Brightman, Fincham, Rhodes, Anyieni, Bcom) in different ways. In common, change management is a transformation process in strategy, processes and human resources. International research by McKinsey shows that $70 \%$ of corporate transformations fail. 39\% of failures are explained by the resistance of employees to changes, $33 \%$ by the lack of support for changes from the managers, and only $14 \%$ by inadequate resources and other reasons. Thus, the corporate culture is a crucial factor in making changes (Shapenko, 2017). There are many reasons to study change management, both from a corporate or personal point of view. Change management helps to understand the environment at the micro and macro levels, supports corporate goal setting, supports corporate goal setting; and contributes to developing and implementing effective strategies assessing the impact of change on external and internal activities. Change management is also vital for the employees themselves. Change management is also vital for the employees themselves. Employees receive change management plans, hence their understanding and involvement in change is important for the organization's survival or growth. Therefore, implementing change management through training and establishing high-performance practices is critical to building robust organizations.

This paper aims to discuss the role and significance of change management models and compare popular models used by organizations to effectively manage the transition stage. The article also attempts to systematize the knowledge associated with change management and the main models related to this issue. To achieve this goal, an exploratory analysis of the literature on this topic was carried out, oriented approaches, and the models based on which effective change management is carried out. The author has studied four mostly used models adopted by organizations for change management and has compared these models: Lewin's model of change; theory E and theory O of organizational change; ADKAR model; and Kotter`s model.

The theoretical background section is based on comprehensive literature review for introduction major models; result section compare various advantages and disadvantages are identified for each model and recommendations and implications for research as well as management are introduced. 


\section{Theoretical background}

Nowadays, change is synonymous with standard business practice, and business needs to change to develop and be competitive. There is a large number of literature sources from several disciplines dealing with change management and its critical success factors. It is a complex topic with many contradictions (Anyieni, 2016). Though the term change management did not discourse much before the 1990s, another term, "organizational," had been used, yet shared almost similar meaning to change management (Farias \& Johnson, 2000).

The exact term of 'change management' was only concretized later in the 1960s and has developed since then (Cooperrider \& Sekerka, 2006). Moran and Brightman (2001) characterized change management as "the process of continually renewing an organization's direction, structure, and capabilities to serve the ever-changing needs of external and internal customers". According to Fincham and Rhodes (2006), "change management is the leadership and direction of the process of organizational transformation, especially with regard to human aspects and overcoming resistance to change." Anyieni, Bcom, and Campus (2013) further argue that change management means planning, initiating, realizing, controlling, and stabilizing change processes on both corporate and personal levels. Nickolas (2006) argues that the task of managing change includes its impact on people, and many managers find this difficult. Change may cover such diverse problems as strategic direction or personal development programmers for staff. Strategic, technological, and structural changes, as well as changes in attitudes and behaviors, are all aimed at competitiveness and viability.

Change management is important for the sustainability and growth of organizations (Lozano, 2013). The aim of the change within organizations is to progress from the existing state to a required state (Ragsdell, 2000). This range from small changes (Dawson, 1994; Doppelt, 2003a; Gill, 2003) to more fundamental ones (Dawson, 1994; Maurer, 1996; Meyerson, 2001; McGahan, 2004).To date, the theory of organizational change offers a large number of different models of change management that allow you to develop a common ideology and concept of change and are an excellent practical guide. In this paper four well-known models are discussed which are: Lewin's model of change; the theory of $\mathrm{E}$ and the theory of $\mathrm{O}$ organizational changes; ADKAR model; and Kotter's model. This section provides information on the indicated change models and is based on the extensive literature in this area. 


\section{Kurt Lewin's model of changes}

Lewin's change model is one of the first models of organizational change and can be called classical. The three-step approach by Kurt Lewin suggests that understanding change involves an awareness of the concept of stability. The factors that "push" for change and the forces aimed at maintaining stability, he called, respectively, "motivating" and "limiting" forces. If these forces are equal, the organization remains stable. Lewin suggested a way of looking at the overall process of making changes. He proposed that organizational changes have three steps:

1. "Unfreezing." The first step involves unfreezing the current state of affairs. It contains defining the current state, surfacing the driving and resisting forces, and picturing the desired end state (Cameron, Green, 2019). It is necessary to justify the need for changes and describe in detail the proposed methods of reform. This stage aims to motivate the business for a change.

2. "Moving." This step is about moving to a new state through participation and involvement. At this stage, planned actions are performed to change the behavior of employees.

3. "Freeze." The third focuses on stabilizing the new state of affairs by setting policy, rewarding success, and establishing new standards (Cameron, Green, 2019). Activities aimed at the consolidation of new organizational practices. It is necessary to convince the staff of the organization of the effectiveness of new methods, promoting the benefits of the new system.

The three-step approach to change requires investment in significant resources (Levin, 1951). Despite its apparent simplicity, it is also argued that Lewin's theory focused on the magnitude of change while ignoring the speed of change hence not applicable in radical processes (Quinn, 1980-1982). Quinn opines that it is often a question of time before incremental change results in comprehensive transformations. Of note is the fact that Lewin's change model focuses on behavioral changes from diverse angles such as group, organizational and societal change (Dickens and Watkins, 1999), but to the contrary, the applicability of rapid and transformational changes only works best in situations that demand major structural adjustments (Cummings \& Worley, 1997). The other argument established was that Lewin's theory ignored the role of politics and power as far as conflicts in organizations are to be discussed (Dawson, 1994); Hatch, 1997); Wilson, 1992). The other criticism was derived from Lewin's idea that top-down management systems worked best for change implementation, unlike the bottom-up management system (Dawson, 1994); Wilson, 1992). 


\section{Theory $E$ and $O$ of organizational change}

Every business's change initiative is unique, and s there are two archetypes, or theories, of change. These archetypes are based on very different and often unconscious assumptions by senior executives - and the consultants and academics who advise them - about why and how changes should be made. Theory $\mathrm{E}$ is change based on economic value. Theory $\mathrm{O}$ is change based on organizational capability. Both are valid models and achieves some of management's goals, either explicitly or implicitly (Nohria, Beer, 2020). Theory E and Theory $\mathrm{O}$ are not mutually exclusive. For example, reducing occupancy costs (Theory E) while increasing flexible work policies (Theory $\mathrm{O}$ ) are not at odds with each other; they are complementary strategies. The managers who follow the "E theory" apply rather hard methods, as a rule, dwelling upon changes fulfillment up and down and attaching importance to the creation of certain structure, which means that a mechanistic approach is applied. The followers of "O theory" - are mostly oriented to the staff training and development, changes of corporate culture, and the changes up and down. The characteristics of these theories are presented in Table 1.

Table 1: Theory E and O

\begin{tabular}{lll}
\hline Characteristics & $\begin{array}{l}\text { "Theory E" (authoritarian style } \\
\text { of management) }\end{array}$ & $\begin{array}{l}\text { "Theory O" } \\
\text { (democratic style of management) }\end{array}$ \\
\hline Changes Goal & $\begin{array}{l}\text { Income rise (economic goals) } \\
\text { Leadership }\end{array}$ & $\begin{array}{l}\text { Is spread according to the } \\
\text { principle up and down } \\
\text { changes }\end{array}$ \\
$\begin{array}{ll}\text { The structure and system } \\
\text { ("hard" elements) }\end{array}$ & $\begin{array}{l}\text { All links are involved } \\
\text { Organizational structure ("soft" } \\
\text { elements) }\end{array}$ \\
$\begin{array}{ll}\text { Changes Planning } \\
\text { Changes Motivation }\end{array}$ & $\begin{array}{l}\text { Programmed Planned Changes } \\
\text { The Consultants Part }\end{array}$ & $\begin{array}{l}\text { Spontaneous Changes (the reaction } \\
\text { to possibilities which occur) }\end{array}$ \\
$\begin{array}{l}\text { According to an approach to } \\
\text { technologies and decisions } \\
\text { fulfillment in the system of } \\
\text { company management }\end{array}$ & $\begin{array}{l}\text { The formation of measures for } \\
\text { organizational changes in the } \\
\text { system of management of } \\
\text { higher link of managerial staff }\end{array}$ & $\begin{array}{l}\text { The combination of different stimulus } \\
\text { Staff involvement into the decision- } \\
\text { making process }\end{array}$ \\
\hline
\end{tabular}

Source: Michael Beer and Nytin Norhia, (2000) 


\section{Awareness, Desire, Knowledge, Ability, Reinforcement (ADKAR) Model}

The ADKAR Model (Hiatt, 2013) focuses on people change adaptation, as opposed to the change itself. ADKAR is an acronym that represents the five tangible and concrete outcomes that people need to achieve for lasting change: awareness, desire, knowledge, ability and reinforcement.

Figure 1: ADKAR Model

\begin{tabular}{|c|c|c|c|c|}
\hline $\begin{array}{c}\text { Understand } \\
\text { need for change }\end{array}$ & $\begin{array}{c}\text { Support of } \\
\text { change. } \\
\text { Participate and } \\
\text { engage }\end{array}$ & $\begin{array}{l}\text { How to change } \\
\text { and what the } \\
\text { change entails }\end{array}$ & $\begin{array}{l}\text { Skills required } \\
\text { to implement } \\
\text { change }\end{array}$ & $\begin{array}{c}\text { To maintain } \\
\text { and sustain } \\
\text { change }\end{array}$ \\
\hline
\end{tabular}

Source: Haitt, J.M. and Creasey, T.J. (2013).

\section{Kotter's 8-Step Model}

Kotter's 8-step change model is a popular framework for successful organizational change implementation utilized in many industries. Kotter's change model emphasized the importance of a holistic approach to change, and the probability of successful implementation of organizational changes is only 30\%. Although employees will see progress, leaders must be prepared to face opposition from within the organization. The way forward is by formally addressing the opposition and highlighting the contradictions in the resistant idea that the new practice is intended to overcome (Hultman, 2003). However, the theory does not understand that there is no fixed parameter to legitimize a vision. It is also the duty of the leadership to estimate the vision set based on a shared understanding with the coalition team. While it focuses primarily on rolling out your changes everywhere, Kotter's model is essentially a top-down approach. The employees do not have input or the choice to share thoughts before strategic vision creation. Another drawback happens if a stage is skipped or executed erroneously, influencing different advances, and leaving the association and venture group to defer or relapse. As a result, there could be wasted time and effort (Galli, 2018). 
Figure 2: Kotter`s 8-Step Model

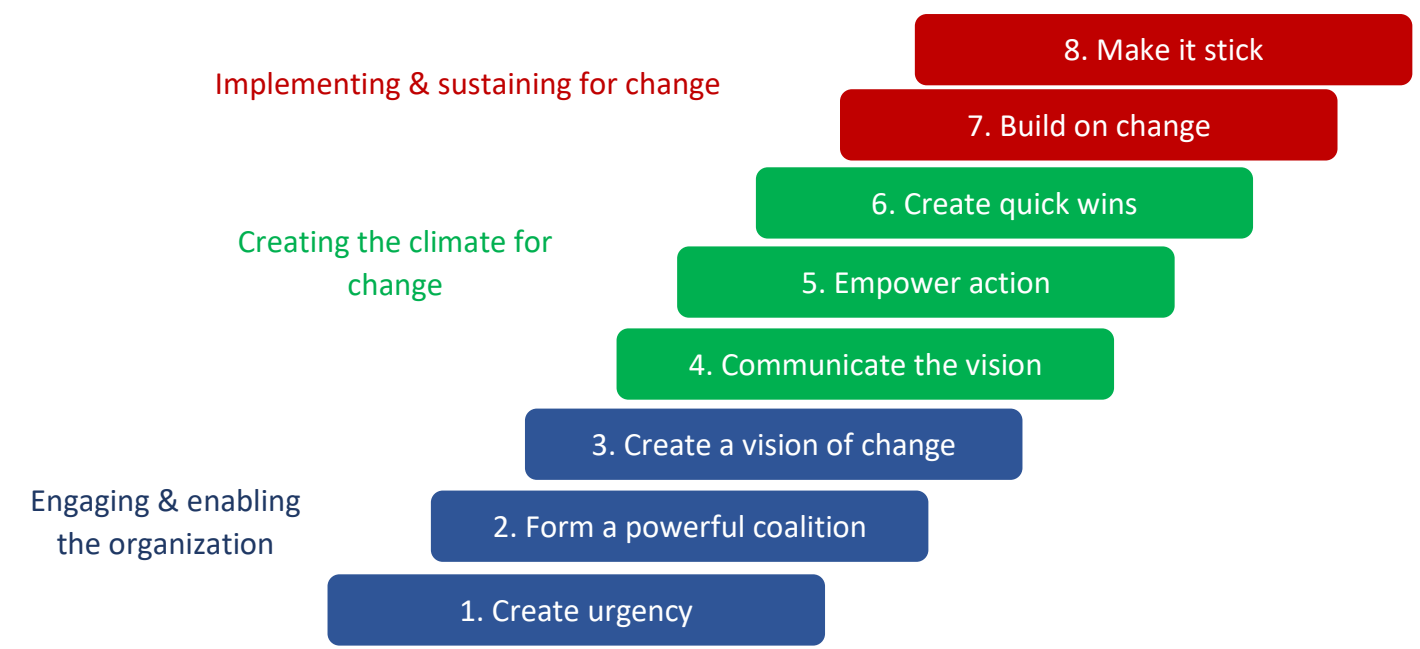

Source: Adapted from Kotter (1996)

\section{Methods}

This article uses a comprehensive literature review that explores, criticizes, and synthesizes representative material on key variables in effective change management. Essential research findings have been incorporated into the literature, and new concepts have been developed on this topic that can be empirically tested in future research. The methodological and theoretical basis of the article is scientific research by Kotter, J.P., Lewin, K. Michael Beer, and Nytin Norhia and others. Search Code: TITLE-ABS-KEY ("Change Management" OR "Change management models," AND "Approaches" OR "Business Transformation" OR "Organizational Change"). The main information base of the study was data from EconBiz, Emerald Insight, McKinsey \& Companies. Literature collection on 20/12/2020 included 57 citations, 25 articles retrieved for final screening, 3 articles excluded after full text screening, 22 articles included in analysis. In the process of writing the article, Kazakh and foreign periodicals were also analyzed. Information sources on the Internet, official websites of international organizations also served as sources of additional information. 


\section{Results}

To date, the theory of organizational change offers a large number of different models of change management that allow developing a common ideology and concept of change. The most exciting and useful are: the Lewin's model of change, the theory of E, and the theory of $\mathrm{O}$ of organizational changes; the Awareness, Desire, Knowledge, Ability, Reinforcement (ADKAR) model; and finally, Kotter's model on change management. Each model helps to understand the fundamental concept of change management, which begins with the current state and realizes the need for change, enters the transition phase, implements the change, and then moves to the desired state and bellow the author detailed comparative analysis of change management models.

Table 2: Comparison of change management models

\begin{tabular}{|c|c|c|c|c|}
\hline Point & $\begin{array}{c}\text { Lewin's change } \\
\text { management } \\
\text { model }\end{array}$ & $\begin{array}{c}\text { Theory } \mathrm{E} \text { and } \mathrm{O} \text { of } \\
\text { organizational } \\
\text { change }\end{array}$ & $\begin{array}{l}\text { Kotter's change } \\
\text { management model }\end{array}$ & $\begin{array}{l}\text { ADKAR } \\
\text { model }\end{array}$ \\
\hline 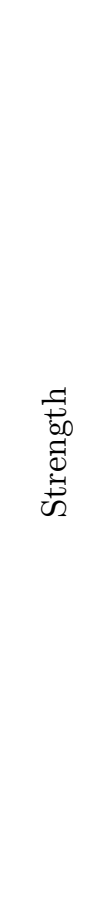 & $\begin{array}{l}\text { The model is } \\
\text { suitable for } \\
\text { cases where a } \\
\text { business needs } \\
\text { to change } \\
\text { dramatically in } \\
\text { order to be } \\
\text { successful. It } \\
\text { also does a } \\
\text { great job of } \\
\text { spotting hidden } \\
\text { bugs that were } \\
\text { taken for } \\
\text { granted as } \\
\text { there are need } \\
\text { to analyzed } \\
\text { every aspect of } \\
\text { what you are } \\
\text { changing. }\end{array}$ & $\begin{array}{l}\text { The choice of an } \\
\text { approach depends } \\
\text { on factors: the } \\
\text { nature and scale of } \\
\text { the problem facing } \\
\text { the organization; } \\
\text { the nature and } \\
\text { content of work in } \\
\text { the organization; } \\
\text { personal } \\
\text { characteristics of } \\
\text { employees; } \\
\text { leadership style and } \\
\text { the value } \\
\text { orientation of } \\
\text { management. }\end{array}$ & $\begin{array}{l}\text { The first few phases are } \\
\text { fantastic - it set the } \\
\text { stage for success by } \\
\text { creating a sense of } \\
\text { urgency and convincing } \\
\text { everyone why change is } \\
\text { needed. This gives the } \\
\text { incentive it needs to } \\
\text { implement the change, } \\
\text { and enough people are } \\
\text { working to implement it, } \\
\text { and this should quickly } \\
\text { become standard } \\
\text { practice. }\end{array}$ & $\begin{array}{l}\text { Focuses on the } \\
\text { activities for } \\
\text { achieving } \\
\text { results, model } \\
\text { is more } \\
\text { beneficial for } \\
\text { integrating the } \\
\text { management } \\
\text { concepts. }\end{array}$ \\
\hline
\end{tabular}




\begin{tabular}{|c|c|c|c|c|}
\hline Point & $\begin{array}{c}\text { Lewin's change } \\
\text { management } \\
\text { model }\end{array}$ & $\begin{array}{c}\text { Theory } \mathrm{E} \text { and } \mathrm{O} \text { of } \\
\text { organizational } \\
\text { change }\end{array}$ & $\begin{array}{c}\text { Kotter's change } \\
\text { management model }\end{array}$ & $\begin{array}{l}\text { ADKAR } \\
\text { model }\end{array}$ \\
\hline 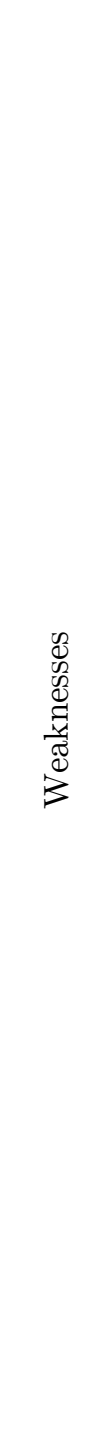 & $\begin{array}{l}\text { Due of the } \\
\text { scale of the } \\
\text { defrosting } \\
\text { process, the } \\
\text { Levin model } \\
\text { can be difficult } \\
\text { and time- } \\
\text { consuming to } \\
\text { implement, } \\
\text { meaning that } \\
\text { the use of the } \\
\text { model is often } \\
\text { only needed for } \\
\text { in-dept analysis } \\
\text { and overhaul. } \\
\text { Massive } \\
\text { changes (for } \\
\text { which this } \\
\text { model is } \\
\text { suitable) are } \\
\text { fraught with } \\
\text { the risk of } \\
\text { employee } \\
\text { churn, as their } \\
\text { workflow will } \\
\text { be radically } \\
\text { different from } \\
\text { the previous } \\
\text { one. }\end{array}$ & $\begin{array}{l}\text { The model cannot } \\
\text { be executed } \\
\text { efficiently in a short } \\
\text { time or in a short } \\
\text { period of time. You } \\
\text { will not have the } \\
\text { necessary knowledge } \\
\text { to evaluate every } \\
\text { element of your } \\
\text { company, and } \\
\text { therefore need to } \\
\text { allocate additional } \\
\text { time and resources } \\
\text { to build an } \\
\text { overview and } \\
\text { evaluate viable } \\
\text { changes. }\end{array}$ & $\begin{array}{l}\text { While it focuses } \\
\text { primarily on rolling out } \\
\text { changes everywhere, } \\
\text { Kotter's model is } \\
\text { essentially a top-down } \\
\text { approach. This is likely } \\
\text { because much of } \\
\text { Kotter's experience } \\
\text { came from working with } \\
\text { large companies, but it } \\
\text { can nevertheless be a } \\
\text { problem for companies } \\
\text { relying on more } \\
\text { collaborative } \\
\text { customization. Not } \\
\text { suitable for a small } \\
\text { company. Model the } \\
\text { most limited on the } \\
\text { people aspect. }\end{array}$ & $\begin{array}{l}\text { Model is } \\
\text { limited when } \\
\text { seeking large- } \\
\text { scale } \\
\text { implementatio } \\
\text { ns Failure to } \\
\text { effectively } \\
\text { understand } \\
\text { and manage } \\
\text { why change } \\
\text { management } \\
\text { initiatives are } \\
\text { labelled } \\
\text { nebulous and } \\
\text { trivial } \\
\text { businesses. }\end{array}$ \\
\hline 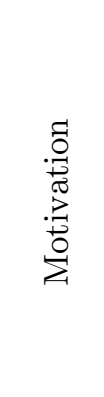 & $\begin{array}{l}\text { Must use } \\
\text { organizational } \\
\text { incentives that } \\
\text { support, not } \\
\text { lead the desire } \\
\text { for people to } \\
\text { make change } \\
\text { real. }\end{array}$ & $\begin{array}{l}\text { Must use financial } \\
\text { incentives that } \\
\text { support, not lead } \\
\text { the desire for people } \\
\text { to make change } \\
\text { real. }\end{array}$ & $\begin{array}{l}\text { Must use cultural- } \\
\text { organizational incentives } \\
\text { that support, not lead } \\
\text { the desire for people to } \\
\text { make change real. }\end{array}$ & $\begin{array}{l}\text { Provides a } \\
\text { simple, easy- } \\
\text { to-use } \\
\text { framework for } \\
\text { everyone } \\
\text { involved in } \\
\text { managing } \\
\text { change. }\end{array}$ \\
\hline
\end{tabular}




\begin{tabular}{|c|c|c|c|c|}
\hline Point & $\begin{array}{c}\text { Lewin's change } \\
\text { management } \\
\text { model }\end{array}$ & $\begin{array}{c}\text { Theory } \mathrm{E} \text { and } \mathrm{O} \text { of } \\
\text { organizational } \\
\text { change }\end{array}$ & $\begin{array}{l}\text { Kotter's change } \\
\text { management model }\end{array}$ & $\begin{array}{l}\text { ADKAR } \\
\text { model }\end{array}$ \\
\hline 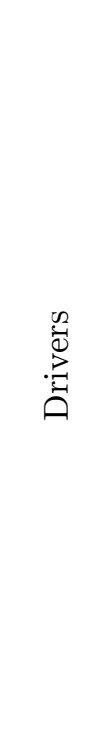 & $\begin{array}{l}\text { Lewin } \\
\text { emphasized the } \\
\text { importance of } \\
\text { preparing } \\
\text { individuals for } \\
\text { change } \\
\text { (unfreezing) } \\
\text { and reinforcing } \\
\text { the need for } \\
\text { change } \\
\text { (freezing). } \\
\text { Sponsorship } \\
\text { would certainly } \\
\text { play a part in } \\
\text { this. }\end{array}$ & $\begin{array}{l}\text { Incorporates } \\
\text { relevant change } \\
\text { agents, stakeholders } \\
\text { and team members } \\
\text { to make an effective } \\
\text { change that } \\
\text { accelerates the } \\
\text { process of change. }\end{array}$ & $\begin{array}{l}\text { The guiding coalition } \\
\text { and volunteer army are } \\
\text { important steps in } \\
\text { Kotter's process. They } \\
\text { both play crucial } \\
\text { sponsorship roles. }\end{array}$ & $\begin{array}{l}\text { Use of key } \\
\text { business } \\
\text { leaders as } \\
\text { sponsors of } \\
\text { change, and of } \\
\text { managers and } \\
\text { supervisors as } \\
\text { coaches to } \\
\text { employees } \\
\text { during the } \\
\text { change } \\
\text { process. }\end{array}$ \\
\hline 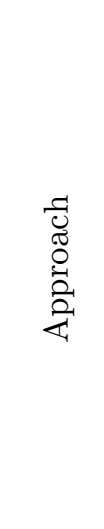 & $\begin{array}{l}\text { Involving the } \\
\text { people in the } \\
\text { process, } \\
\text { allowing them } \\
\text { time to shift, } \\
\text { and talking to } \\
\text { external } \\
\text { stakeholders } \\
\text { (e.g., employee } \\
\text { organizations) } \\
\text { if required. }\end{array}$ & $\begin{array}{l}\text { Top-down: the } \\
\text { employees do not } \\
\text { have input or the } \\
\text { option to share } \\
\text { ideas before } \\
\text { strategic vision } \\
\text { creation. }\end{array}$ & $\begin{array}{l}\text { Top-down: the } \\
\text { employees do not have } \\
\text { input or the option to } \\
\text { share ideas before } \\
\text { strategic vision creation. }\end{array}$ & $\begin{array}{l}\text { The model } \\
\text { works best } \\
\text { with } \\
\text { individuals, } \\
\text { rather than } \\
\text { groups or } \\
\text { entire } \\
\text { organizations. } \\
\text { Involving the } \\
\text { people in the } \\
\text { process. }\end{array}$ \\
\hline
\end{tabular}




\begin{tabular}{|c|c|c|c|c|}
\hline Point & $\begin{array}{l}\text { Lewin's change } \\
\text { management } \\
\text { model }\end{array}$ & $\begin{array}{l}\text { Theory } \mathrm{E} \text { and } \mathrm{O} \text { of } \\
\text { organizational } \\
\text { change }\end{array}$ & $\begin{array}{l}\text { Kotter's change } \\
\text { management model }\end{array}$ & $\begin{array}{c}\text { ADKAR } \\
\text { model }\end{array}$ \\
\hline 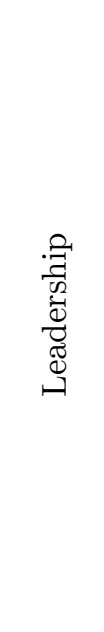 & $\begin{array}{l}\text { Defined as the } \\
\text { influence of } \\
\text { certain } \\
\text { individuals in } \\
\text { the group to } \\
\text { achieve } \\
\text { common goals. } \\
\text { A well-planned } \\
\text { change process } \\
\text { requires } \\
\text { defining a } \\
\text { vision and } \\
\text { motivation. }\end{array}$ & $\begin{array}{l}\text { Must be } \\
\text { participative top- } \\
\text { down, so that the } \\
\text { top leaders quickly } \\
\text { develop the goals } \\
\text { and encourage } \\
\text { middle layers of } \\
\text { management to } \\
\text { adopt them, and } \\
\text { middle management } \\
\text { works influence } \\
\text { upward. }\end{array}$ & $\begin{array}{l}\text { Need a strong leadership } \\
\text { culture. The leaders } \\
\text { need to develop a well- } \\
\text { designed plan. }\end{array}$ & $\begin{array}{l}\text { Allows leaders } \\
\text { and teams to } \\
\text { focus their } \\
\text { activities on } \\
\text { what will drive } \\
\text { individual } \\
\text { change and } \\
\text { therefore } \\
\text { achieve } \\
\text { organizational } \\
\text { results. }\end{array}$ \\
\hline 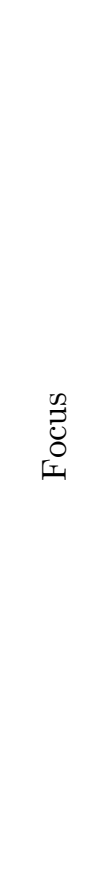 & $\begin{array}{l}\text { Given the } \\
\text { absent of } \\
\text { technology, } \\
\text { changes per se } \\
\text { were static. } \\
\text { The results of } \\
\text { change could } \\
\text { thus be } \\
\text { predicted; the } \\
\text { methods to } \\
\text { manage change } \\
\text { do not vary, } \\
\text { and hence } \\
\text { planning has a } \\
\text { critical role in } \\
\text { the } \\
\text { management of } \\
\text { change. }\end{array}$ & $\begin{array}{l}\text { A combination of } \\
\text { planned/programma } \\
\text { tic change with } \\
\text { opportunistic } \\
\text { capture of emergent } \\
\text { practices. }\end{array}$ & $\begin{array}{l}\text { The need to create short } \\
\text { wins can actually } \\
\text { increase the sense of } \\
\text { true urgency and } \\
\text { actually accomplishing } \\
\text { these goals does much to } \\
\text { cement the change } \\
\text { initiative. }\end{array}$ & $\begin{array}{l}\text { Most effective } \\
\text { when } \\
\text { managing staff } \\
\text { in helping } \\
\text { them see and } \\
\text { accept the } \\
\text { value of } \\
\text { change and } \\
\text { their role } \\
\text { within the } \\
\text { organization in } \\
\text { helping to } \\
\text { make that } \\
\text { change } \\
\text { happen. }\end{array}$ \\
\hline
\end{tabular}

Source: Completed by the author on the basis of sources considered.by Kotter (1996), Haitt and Creasey (2013), Michael Beer and Nytin Norhia (2000), Cameron, Green (2019). 
Lewin's model has had a significant impact on the further development of the theory of organizational change. Lewin's model requires in-depth analysis and process improvements. By uncovering the roots of your methods and completely changing processes and practices where necessary can change an organization at a critical time in its life cycle. Lewin's ideas are valuable when analyzing the change process at the start of an initiative. His forcefield analysis and current state/end state discussions are extremely useful tools. However, the model loses its worth when it is confused with the mechanistic approach, and the three steps become: 'plan, implement, and review.' Theory E and Theory $\mathrm{O}$ are two polar approaches to organizational change, representing two different strategies for the process of change. Theory $\mathrm{E}$ and $\mathrm{O}$ of organizational change's model is suited for those who want to know how they can change for the better. Having created an overview of how consistent and effective various elements of the company are, there are needed leaders and good employee support. Then proceed to analyze the current situation and develop changes to solve the problem model that combines a number of key elements management model of organizational change together in a neat process. The ADKAR model is founded on three phases and it deals with the process and steps to manage change. It is a goal-oriented model and focuses on the activities for achieving results. The ADKAR model is more beneficial for integrating the management concepts in the change management process (Siddiqui, 2017). Kotter's theory is great as a checklist but lacks the necessary actionable instructions to be taken as a step-by-step process. Kotter's model should be supplemented with other approaches or at least their elements to make up for its shortcomings. The model places most emphasis on getting the early steps right: building a coalition and setting the vision rather than later stages of empowerment and consolidation. Change is seen as linear rather than cyclical, which implies that a pre-designed aim.

\section{Discussion and recommendations}

According to the reviewed material, it should be noted that there is no one ideal specific version of change management. The choice of an approach should be based on consideration of real conditions, as well as on the integration of several models. In an attempt to compare popular change management models from theoretical viewpoint were considered and the study is open to future research and a deeper understanding of the changes and will help future researchers with suggestions.

The study suggests that for future research, sufficient time should be allocated for more in-depth analysis, and the practical component should be considered. This is beneficial to the extent that it allows the researcher to find many companies that will be included in the data collection process. This will provide a real picture of the theories from the practice 
side in real organizations. The empirical validation of will allow to investigate the efficiency of change management models implementation at a company depending on management style (authoritative or democratic), and to investigate the practical value of received results. Limitations of paper are determined by results based on secondary data and making assumptions based on some old data. Therefore, future researchers are encouraged to constructively criticize, propose alternatives and solve academic problems, and most importantly-to be flexible and adaptive to new concepts of change management.

\section{References}

Abel Anyieni (2016), Organisational Change: A Critical Review of the Literature, https://www.semanticscholar.org/paper/Organisational-Change\%3A-A-Critical-Reviewof-the-Anyieni/168d486f3a71fd19bd9a92e8623e808728ddd9ce

Dawson, P. (1994). Organizational change: A processual approach. London: Paul Chapman.

Esther Cameron \& Mike Green (2009). Making sense of change management, Lndon and Philadelphia 2nd edition.

Fincham, R. and Rhodes P. (2005).Principals of Organisational Behaviour. Oxford University Press

Galli B.J. (2018). Change Management Models: A Comparative Analysis and Concerns IEEE Engineering management review. 46, NO. 3.

Haitt, J.M and Creasey, T.J.(2013). Change Management: the people side of change. Colorado: Prosci Learning Center Publication

Kotter, J. P. (1996). Leading change. Cambridge, MA, USA: Harvard Business School Press.

Lewin, K. (2016). Available: http://change-management-consultant.com/kurtlewin.html.

Lozano, R. (2013). Corporate Social Responsibility and Environmental Management. Are companies planning their organisational changes for corporate sustainability? An analysis of three case studies on resistance to change and their strategies to overcome it, 20(5), 275-295.

Moran, J. W., \& Brightman, B. K. (2001). Career Development International,6(2). Leading organizational change, pp. $111-118$.

Nitin Nohria and and Michael Beer (2000). Business Harvard review. Cracking the Code of Change, https://hbr.org/2000/05/cracking-the-code-of-change.

Saima Tabassum Siddiqui (2017). International Journal of Advanced Research. A critical review of change management strategic and models, 5(4), 670-676

Shapenko A, Filippova M. (2010) Business Harvard review. The burden of change. 


\title{
The Impact of the Quality of Public Spending and Institutional Change on the Use of Oil Royalties: Exploring Public Management Research
}

\author{
CLAUDIA DA SILVA JORDÃO* \\ *Corvinus University of Budapest, Institute of Management; \\ claudia.jordao@stud.uni-corvinus.hu
}

DOI: $10.14267 / 978-963-503-867-1 \_11$

\begin{abstract}
The aim of the paper is to analyze the impacts of the quality of public spending and institutional change on the use of oil royalties. The related research is based on the (re)definition of concepts that are crucial for scholars in public administration. The debate on their utilization involves social and environmental issues, not limited to economic growth. Given the current economic crises faced by governments, there is a more significant limitation on public resources available by local governments. Therefore, one should not ignore the window of opportunity that has opened to give due attention to the quality of public spending. The research has also adopted the New Institutionalism theory that has as a premise that the institutions exert influence on the behavior of actors and on the political decisions. As a result, it is concluded that there is path dependence. The arguments of path dependence and increasing returns are used to explain the continuities. In the institutional analysis, the concept of path dependence helps to understand the possible behavior of economic agents. Thus, in this context, the economy does not represent an increase in the population's quality of life, and it is necessary to build a work methodology that involves the knowledge of local needs.
\end{abstract}

Keywords: quality of public spending, institutional change, oil royalties, public management

Funding: The present publication is the outcome of the project "From Talent to Young Researcher project aimed at activities supporting the research career model in higher education," identifier EFOP-3.6.3-VEKOP-16-2017-00007 co-supported by the European Union, Hungary, and the European Social Fund. 


\section{Introduction}

This paper deals with the study of oil royalties focusing on two central themes: the quality of public spending and institutional change. The theoretical contribution of the paper directly impacts the debate on the quality of public expenditure. It represents a significant portion of the budget utilization at any municipality. It is also important to highlight the negative impact that the mismanagement and improper use of this public money can make on the wellbeing of the population - especially of those who are the neediest of vital public services.

The concept of growth must also involve institutional change and local governance capacity. Evans (2003) points out that growth is centered on ideas and is the result of the actions of the anticipatory economic agents that respond to incentives. Thus, institutional arrangements begin to direct the incentives to develop ideas and become determinant for the rate of growth. This theory holds that basic institutions of governance are capable of playing a relevant role in generating development. However, the application of development planning must take into account the local culture, and the institutional change is based on local decision-making. Otherwise, imposing a planning model already pre-established without adaptation to reality, there is little possibility of success.

Regarding the use of oil royalties, Alves (2011) points out that there is a social purpose, and it is related to the idea of sustainable development, not limited to short and mediumterm objectives. According to Reis and Santana (2014), the reason for royalties is precisely to guarantee sustainable development, which would require that the resources from royalties be used in public investments aimed at the constitution of fixed assets and the formation of people. However, its use, although it has some legal provisions to guide spending actions, is not well defined - which gives greater freedom to local managers. In this way, the debate focused on the construction of the social purpose of royalties would then take place from a theoretical framework that encompassed the concepts of mineral income, cost of use, and intergenerational economic sustainability. 


\section{Theoretical background}

\section{Quality of public spending: a necessary conceptual definition}

What is public spending? Investment or costing? Investment is intended to expand future opportunities, but at the same time, investment also represents an outflow of money - an outflow of money to generate new inflows. Government spending comes from taxes that citizens pay. Public spending must be supported by law and must be budgetary. That is, it must have the legislative authority to carry out the expenditure. But public spending, in general, is not strictly government spending (based on budgetary decisions and bidding processes). In recent decades the definition of public spending has expanded and incorporated new relationships between government and private suppliers of public goods - such as, for example, partnerships between public and private (non-state expenditure, the one made for public purposes, but with private financing or partially private).

When can public spending be considered of high quality? As pointed out by Motta et al. (2014), there is still some difficulty in building a consensus on the strategies and measures necessary to implement the concept of quality of public spending. This concept, in turn, is relatively recent both in public bodies and in the academic field. Its conception involves the search for efficiency, effectiveness, and combating corruption. In a more normative view, the concept of quality of public spending has been used to charge governments for economic and social returns from the payment of taxes. An important fact for reflection is to consider its two general dimensions: one is its macroeconomic essence, which involves a strategic bias in the allocation of public resources and their impacts; the second dimension is microeconomic, which focuses on operational aspects of public spending.

Quality of public spending becomes a strategic instrument that enables the state to act in the economy and society, implementing public policies, focusing on fiscal balance. The way the state decides to implement its resources defines the means and priorities to meet social demands. Motta et al. (2014) highlight that government behavior will determine economic growth under the items of costing (government expenditure), capital formation (public investment), and income transfer policies. In some cases, depending on the government program, even in the items based on government funding, they can generate long-term impacts on the economic structure, both due to the accumulation of physical capital and investment. Thus, government action does not represent an increase only in costs but also in the accumulation of human capital and productivity. To allow for a better allocation of public resources, the legal support system (the concept of efficiency) and accounting (dimension of expenditure) need to be adjusted. 
As summarized by Pires (2009), the operational dimensions of the quality of public spending are efficiency, efficacy, effectiveness, transparency, and legality (verifiable, evaluable), ensuring economy, and legitimacy (partly embedded in legality). Sustainability is added, which argues that public spending should advance only to the extent that it can be sustained by levels of taxation and public debt.

\section{Institutions and institutional change}

From an institutionalist perspective, institutions are studied against the theoretical perspective of methodological individualism. From then on, habits and rules are considered. Some elements are considered, for example, 1) there is an emphasis on power relations and conflicts of interest; 2) the economy is no longer seen as self-regulated; 3) the historical process is seen as important for analysis; 4) the individual is not studied separately, but institutionalized. Institutions affect the performance of the economy and can form the incentive structure of individuals. For that, it is essential to give importance to culture, as it is precisely the informal limitations that can explain the path dependence - a term used when the behavior of the past influences the present, even if the current situation requires new responses.

Institutions are the rules of the game, and organizations are the players. The institutions have devised constraints that shape the way people evolve. It has the power to affect the performance of economies, and a differential performance is influenced by the way institutions evolve. They can, in turn, reduce uncertainty, define and limit the choices of individuals. Regardless of being formal or informal, institutions have many forms of constraints, namely formal rules or codes of behavior and conventions. That is, institutional constraints are the framework within which social interaction takes place, and this is the key to understanding historical change (North, 1990).

As mentioned above, the main purpose of the rules is to define the way of the game, create stability and reduce the costs of human interaction, but that does not mean that they are not changing. The institutional change is, most of the time, incremental, and together with the way by which the actors make choices account for path dependence. Institutional change is a complicated process because it may be related to several factors, such as rule changes or some informal constraints. As highlighted by North (1990), formal constraints are the results of political or judicial decisions, but informal constraints are much harder to detect. These cultural/informal constraints connect the past with the present and show up as an important key to explaining the path of historical change. 
Informal constraints come from socially transmitted information and are part of the heritage. That is, they can be transmitted by values and knowledge that influence the behavior, and there is the power of internally enforced codes of conduct that modify this behavior. The way how the mind processes information is the key to understand how the informal constraints influence the choice set. North (1990) explores the argument that incremental changes in such informal constraints will alter the game to increase or decrease cooperative outcomes. A transaction cost framework can be indirect evidence of changes in informal constraints and, hence, the transaction cost is a fertile field to explore informal constraints. In brief, the informal constraints (culture) play an important role in the incremental evolution, and hence this is the key to understanding this path dependence. And the tension between altered formal rules and the persisting informal construction produces outcomes that have important implications for the economies.

The arguments of path dependence and increasing returns are used to explain the continuities but also capable of providing plausible elements to explain the institutional change usually stemming from exogenous factors. The changes are never completely discontinuous, they are reconstructed containing previous elements, and even the informal constraints inserted in customs and traditions may remain. Thus, considering the historical analysis may allow elucidating the causal mechanisms that guide the process of ruptures and continuities, that is, the historical analysis that will allow to provide an analytical structure and to explain the relationship between choices, decision processes, institutional arrangements, and the political context. It is necessary to understand how the process of ideas dominates political discourse. In an institutional analysis, the concept of path dependence helps to understand the possible behavior of economic agents. The institutionalist theory considers that economic development is the result of institutions and institutional change, so for innovation to occur, institutional rearrangement is necessary. Technology is a variable resulting from the institutional environment, as technology is directly linked to a system of habits and knowledge shaped by values. Therefore, problem-solving is connected in the same institutional context (Arend et al., 2012). 


\section{Methodology}

As the aim is to analyze the impacts of two variables (quality of public spending and institutional change) on the use of oil royalties, this research focuses on creating some categories of analysis considered as key. As can be seen in the table below, concepts considered the most suitable, "questionable," and that should be avoided were selected to establish analysis criteria with a focus on the objective of the work. These concepts are associated with the quality of spending in the sense that some of them are in line, others are dubious, while the rest are in contrast with the quality of spending.

Table 1: Definition of categories

\section{$\begin{array}{ll}\text { Categories } & \text { Definition }\end{array}$}

Category 1: concept considered the most suitable for the use of public money from oil royaltiesapplications for sustainable development.

Category 2: Concept considered "questionable" for the use of public money from oil royalties.

Category 3: Concept should be avoided for the use of public money from oil royalties.
Type of expense directly related to the concept of sustainable development of the theoretical framework on the quality of public spending. According to Reis and Santana (2014), the proceeds from royalties should be used in public investments aimed at the constitution of fixed assets and the training of people. Adequate use in the formation of capital goods and human capital that follows the diversification of the economy in areas that can promote increased productivity and the average accumulation of capital with a view to economic growth.

Type of expense related to the concept above but not necessarily related to the social purpose of oil royalties. It includes the expenses to fund the maintenance of the activities of public administration bodies.

Type of expense that should be avoided, going to the opposite side of the concept about the good use of oil royalties. Considered as sensitive to corruption, as highlighted by Trevisan et al. (2014). It is included: publicity, events, and publication of official acts.

Source: own compilation 
These categories of analysis are intended to classify expenditures from oil royalties. Therefore, it is possible to analyze the local scenario in terms of whether there is a path dependence on the use of royalties or whether there are elements that classify an institutional change. The categories presented above aim to enable the construction of an overview of the differences regarding the application of the resources of royalties. With this, it aims to facilitate the analysis of its social purpose and the good use of public money.

\section{Results}

To exemplify the topic addressed and apply the analysis categories, data from Macaé City Hall in Rio de Janeiro State (Brazil) were selected. Macaé city is known internationally as the "oil capital" and, in recent years, the economy has grown by 600 percent. According to data from the Getulio Vargas Foundation, Macaé was considered the ninth-best Brazilian city to work in and one of the most dynamic in the country in 2008.

The data in Tables 2-5 represent the types of services managed by Macaé city, whose expenses represented more than 90 percent of the application of post-salt royalties between 2012 and 2014. (The largest oil reserves in Brazil and other countries are at depths ranging from 2000 to 3000 meters. This layer is called the post-salt layer as just below it can be found a geological layer formed by salt with a depth of 3000 to 5000 meters.)

Table 2: Applications considered the most suitable to contribute to sustainable development

\begin{tabular}{|c|c|c|c|c|c|}
\hline Services & 2012 & 2013 & 2014 & Total & Percentage \\
\hline University transport & $8.020 .393,65$ & $1.683 .152,41$ & $1.036 .986,25$ & $10.740 .532,31$ & $3,62 \%$ \\
\hline School feeding & 4.063.930,12 & $1.057 .543,89$ & $4.640 .485,22$ & $9.761 .959,23$ & $3,29 \%$ \\
\hline $\begin{array}{l}\text { Computer rental for } \\
\text { schools }\end{array}$ & 1.509.339,04 & - & - & $1.509 .339,04$ & $0,51 \%$ \\
\hline $\begin{array}{l}\text { Rental and maintenance of } \\
\text { tank trucks }\end{array}$ & - & - & $1.285 .368,87$ & $1.285 .368,87$ & $0,43 \%$ \\
\hline Macaé Digital & $1.152 .133,36$ & - & - & $1.152 .133,36$ & $0,39 \%$ \\
\hline Channel maintenance & - & - & $1.088 .373,70$ & $1.088 .373,70$ & $0,37 \%$ \\
\hline $\begin{array}{l}\text { Outsourcing of labor for } \\
\text { environmental services }\end{array}$ & - & $522.519,80$ & - & $522.519,80$ & $0,18 \%$ \\
\hline Total & & & & $26.060 .226,31$ & $8,79 \%$ \\
\hline
\end{tabular}

Source: Brazilian Transparency Portal (2015). 
Table 3: Applications considered "questionable" to contribute to sustainable development.

\begin{tabular}{|c|c|c|c|c|c|}
\hline Services & 2012 & 2013 & 2014 & Total & Percentage \\
\hline $\begin{array}{l}\text { Maintenance services, } \\
\text { urban and special cleaning, } \\
\text { sweeping and urban } \\
\text { cleaning, landfills, } \\
\text { recycling, aeration, vehicle } \\
\text { rental }\end{array}$ & $35.940 .673,84$ & $28.607 .960,64$ & $39.951 .839,41$ & $104.500 .473,89$ & $35,19 \%$ \\
\hline $\begin{array}{l}\text { Maintenance and } \\
\text { conservation of landfills, } \\
\text { public buildings, parks, } \\
\text { side roads and drainage } \\
\text { networks }\end{array}$ & $40.557 .298,46$ & $2.257 .106,84$ & $58.472 .557,75$ & $101.286 .963,05$ & $34,11 \%$ \\
\hline $\begin{array}{l}\text { Telephony for } \\
\text { administration }\end{array}$ & $894.879,57$ & 2.991.202,48 & $1.713 .892,65$ & $5.599 .974,70$ & $1,89 \%$ \\
\hline $\begin{array}{l}\text { Maintenance of public } \\
\text { buildings for events }\end{array}$ & $5.397 .737,64$ & - & - & $5.397 .737,64$ & $1,82 \%$ \\
\hline $\begin{array}{l}\text { Outsourcing of labor for } \\
\text { administration }\end{array}$ & $1.700 .586,53$ & $2.325 .831,14$ & $47.600,00$ & $4.074 .017,67$ & $1,37 \%$ \\
\hline $\begin{array}{l}\text { Transport to } \\
\text { administrative bodies }\end{array}$ & - & $477.000,00$ & $1.716 .527,06$ & $2.193 .527,06$ & $0,74 \%$ \\
\hline $\begin{array}{l}\text { Re-registration of urban } \\
\text { areas }\end{array}$ & $2.100 .794,64$ & - & - & $2.100 .794,64$ & $0,71 \%$ \\
\hline $\begin{array}{l}\text { Public lighting system } \\
\text { management }\end{array}$ & $1.881 .786,16$ & - & - & $1.881 .786,16$ & $0,63 \%$ \\
\hline Public cleaning & $1.495 .296,50$ & $78.639,05$ & $7.726,00$ & $1.581 .661,55$ & $0,53 \%$ \\
\hline $\begin{array}{l}\text { Development of tax } \\
\text { management system }\end{array}$ & $660.000,00$ & - & $694.062,68$ & $1.354 .062,68$ & $0,46 \%$ \\
\hline $\begin{array}{l}\text { Acquisition of computers } \\
\text { for administration }\end{array}$ & - & $192.260,20$ & - & $192.260,20$ & $0,06 \%$ \\
\hline Total & & & & $230.163 .259,24$ & $77,51 \%$ \\
\hline
\end{tabular}

Source: Brazilian Transparency Portal (2015). 
Table 4: Applications that should be avoided to contribute to sustainable development.

\begin{tabular}{lccccc}
\hline \multicolumn{1}{c}{ Services } & 2012 & 2013 & 2014 & Total & Percentage \\
\hline Government advertising & $14.784 .217,02$ & $9.594 .722,25$ & $6.284 .164,00$ & $30.663 .103,27$ & $10,33 \%$ \\
Event preparation & - & $1.258 .635,19$ & $3.517 .748,00$ & $4.776 .383,19$ & $1,61 \%$ \\
Publication of official acts & $3.278 .169,75$ & $665.490,24$ & - & $3.943 .659,99$ & $1,33 \%$ \\
$\begin{array}{l}\text { Air tickets, transfers, and } \\
\text { accommodation for the }\end{array}$ & $1.360 .989,88$ & - & - & & $1.360 .989,88$ \\
administration & & & & & $0,46 \%$ \\
Total & & & & $40.744 .136,33$ & $13,73 \%$ \\
\hline
\end{tabular}

Source: Brazilian Transparency Portal (2015).

Table 5: The percentage of each category for comparison

\begin{tabular}{lc}
\hline \multicolumn{1}{c}{ Category } & Percentage \\
\hline $\begin{array}{l}\text { Category 1: Applications are considered the most suitable to contribute to } \\
\text { sustainable development. }\end{array}$ & $8,8 \%$ \\
$\begin{array}{l}\text { Category 2: Applications considered "questionable" to contribute to sustainable } \\
\text { development. }\end{array}$ & $77,5 \%$ \\
$\begin{array}{l}\text { Category 3: Applications that should be avoided to contribute to sustainable } \\
\text { development. }\end{array}$ & $13,7 \%$ \\
\hline
\end{tabular}

Source: own compilation

Based on the results obtained, reference tables were elaborated above. Thus, the data indicate that Macaé city, between 2012 and 2014, invested a large part of the resources of post-salt royalties in current expenses that, as defined, are not linked to the formation or acquisition of capital goods to contribute to sustainable development. Through the highlighted tables, the observations indicate that the smallest part of the application of the resources of royalties ( 8.8 percent) fits into the related category more adequately to sustainable development. 77.5 percent of applications, on the other hand, fall into the category that has the potential to contribute to sustainable development, but not necessarily directly. Finally, 13.7 percent of personal applications are related to achievements not linked to the promotion of sustainable development and, therefore, have not been financed from royalties. 
As the studies by Oliveira Junior et al. (2020) point out, Macáe city has the potential to contribute to sustainable development, but without being directly related to its social purpose. But even so, Macaé city brings indicators that there is a need for a greater debate on the need to give the application of royalties a programmatic character, which leads its use to social purposes so that there can be a good use of public spending.

\section{Conclusions}

Actually, why in many local institutions does the misuse of public money still persist? Higher performance to generate quality public spending needs institutional change. This is because changing habits and interests - informal limitations, as mentioned earlier - is really difficult. This makes institutions dependent on their trajectories, and there is no point in simply copying the techniques of other successful institutions because the nature of learning is local and particular. Economic development is the result of the interaction between economics, politics, and culture, and there is a need for cooperation between the agents of the same institutional arrangement (Arendet et al. 2012). Once the oil reserves are exhausted and adding the fact that the environmental deficit generated by oil extraction, the scenario will become different and the local government will be dependent on the old scenario, that is, without new ways to diversify the economy and be independent of oil. Exactly, for this reason, the social purpose of royalties would be intended to enable sustainable development and generate an alternative for new paths. 


\section{References}

Alves, V. R. (2011). Aplicação dos royalties de petróleo e a garantia constitucional do desenvolvimento sustentável. (Dissertação de Mestrado). Universidade Federal do Rio Grande do Norte, Natal.

Arend, M., Cario, S., \& Enderle, R. (2012). Instituições, inovações e desenvolvimento econômico. Revista Pesquisa e Debate, SP, 23(1), 110-133.

Evans, P. (2003). Beyond "Institutional Monocropping": institutions, capabilities, and deliberative development. Sociologias [online], (9), 20-63.

Macaé. (2015). Despesas por Fonte de Recursos. Accessed on 21 de jul. de 2015, available on the Macaé Transparencies Portal: http://sistemas.macae.rj.gov.br/transparencia/index.asp?acao $=3 \&$ item $=6$

North, Douglass C. 1990. Institutions, Institutional Change, and Economic Performance. Cambridge: Cambridge University Press.

Oliveira Junior, T. M., Jordão, C., \& Braga, M. V. (2020). Para que serviram os royalties? Um debate sobre a aplicação da compensação financeira decorrente da exploração de petróleo e gás no município de Macaé. Revista Estudos de Administração e Sociedade, 5(1), 5268.

Pires, V. (2009). Gestão orçamentária e qualidade do gasto público. In Bizelli, José Luís \& Ferreira, Darlene. Governança pública e novos arranjos de gestão. Piracicaba: Jacintha Editores, pp. 55-78.

Reis, D. and Santana, J. 2015. Os efeitos da aplicação dos royalties petrolíferos sobre os investimento públicos nos municípios brasileiros. Revista da Administração Pública, Rio de Janeiro, 49(1), 91-117.

Trevisan, A., Chizzotti, A., Ianhez, J. A., Chizzotti, J., \& Verillo, J. (2004). O Combate à Corrupção nas Prefeituras do Brasil. Cotia: Ateliê Editorial. 


\title{
Professionalization of Family Firms: Striking a Balance Between Personal and Non-Personal Factors
}

\author{
ZOLTÁN KÁRPÁTI* \\ *Corvinus University of Budapest, Institute of Management; \\ zoltan.karpati@uni-corvinus.hu
}

DOI: $10.14267 / 978-963-503-867-1 \_12$

\begin{abstract}
The amount of research on family businesses' analysis has increased significantly in recent years, thus showing the high importance of the topic. In most countries, family businesses occupy a prominent place in contributing to the economy with the added value they produce. However, less attention has been paid to the professionalization of family businesses and the exploration and presentation of the related literature. The professionalization of family business is a significant research concern in the entrepreneurship and governance literature. In the context of family businesses, professionalization initially meant nothing more than hiring an outside, non-family manager. For today, the content of professionalization has expanded, and a multidimensional model has evolved: a broader, deeper understanding has evolved, which involves other vital aspects such as developing formal control and human resource systems, decentralization of authority, formal strategic planning, or top-level activeness. This study aims to present the essential international literature on professionalization and provide a comprehensive overview of the studies published. The literature review mainly summarizes the results of the last twenty years and closely related articles. The paper follows the next logic; in the first part, the definition of professionalization is introduced along with its benefits and challenges. Then, based on the research methodology presented, the related empirical and theoretical studies are examined. In the end, the review summarizes the key findings in a table.
\end{abstract}

Keywords: family firms, professionalization, non-family CEO, multidimensional phenomena

Funding: The author is grateful for the financial support received from the Corvinus Center of Family Business. 


\section{Introduction}

Calls for professionalizing family firms have a long history since family firms were usually depicted as unprofessional or an outdated type of organization (Chandler, 1977). It is also a significant research concern in the entrepreneurship and governance literature (Zhang \& Ma, 2009). As an organization grows over time, more employees and managers are needed to manage the company. In terms of family businesses, early publications identified professionalization as nothing more than the recruitment of a non-family external CEO (see Klein \& Bell, 2007; Zhang \& Ma, 2009), but recent studies and articles (Stewart \& Hitt, 2012; Dekker, Lybaert, Steijvers, Depaire, \& Mercken, 2013; Dekker, Lybaert, Steijvers, \& Depaire, 2015) claimed that professionalization is, in fact, a multidimensional paradigm. It involves the recruitment of external managers and appears in creating formalized systems, be it financial control, management, or human resource systems (Gimeno \& Parada, 2014). This idea is also confirmed by Polat's (2020) study, which is based on theoretical analysis, considers the professionalization of family firms to be a broader concept that includes management structures in addition to hiring external managers, such as boards and councils, formal financial and human resource control mechanisms, or formal strategic planning.

Nonetheless, in most research, professionalization is still identified with recruiting one or more external managers, thus representing a narrow view. Hall and Nordqvist (2008) also address this paradox by stating that family managers are often seen as non-professional managers who have inherited their roles, regardless of their professional and educational background as well as their relationship with the business. And for non-family managers, apart from their experience and their relationship with the company, they seem professional by nature.

My study aims to give an overview of empirical and theoretical studies and present the professionalization of family firms by reviewing and summarizing the relevant international literature. Existing research suggests that family businesses differ in terms of their professionalization (Madison, Daspit, Turner, \& Kellermans, 2018); thus, the presentation of the topic can contribute to a deeper understanding of family business operation and heterogeneity and provide practice-oriented advice and experience for practicing family business leaders. 


\section{Theoretical background}

\section{Defining the phenomena of professionalization}

Professionalization of a firm in mainstream business literature refers to its evolution through its organizational life cycle and consists of applying complex management and organization systems. Such systems may be formal planning, regular scheduled meetings, formal training, performance appraisal systems, defined responsibilities, management development, and formal governance bodies and control systems (Flamholtz \& Randle, 2007). The authors' further addition was that professionalization should also include the transfer of decision-making authority to middle managers, the implementation of formal control systems, changes in decision-making mechanisms, and the organizational structure's possible conversion.

According to Stewart and Hitt (2012) the term professionalization has no ultimate, generally accepted meaning in scientific or public discourse. Based on the most straightforward approach, it means no more than the full-time employment of employees. With a simple addition for family businesses, professionalization means full-time employment and recruiting external, non-family employees, typically with managerial competence. In many publications dealing with family business research, professionalization does not mean more than that (see Gedajlovic, Lubatkin, \& Schulze, 2004; Chittoor \& Das, 2007; Klein \& Bell, 2007; Zhang \& Ma, 2009).

Based on Dekker et al. (2013, p. 84), it can be synthesized that professionalization as a phenomenon cannot be limited to the recruitment of external managers but is accompanied by (1) the development of effective corporate governance systems such as the establishment of boards and councils (Songini, 2006; Flamholtz \& Randle, 2007; Chrisman, Chua, De Massis, Minola, \& Vismara, 2016; Howorth, Wright, Westhead, \& Allcock, 2016), (2) management development as hiring external and non-family members (Songini, 2006; Lin \& Hu, 2007; Yildirim-Öktem \& Üsdiken, 2010; Stewart \& Hitt, 2012) (3) delegating control as a management function and decentralizing authorities (Chua, Chrisman, \& Bergiel, 2009), (4) developing formal financial control mechanisms (Songini, 2006; Flamholtz \& Randle, 2007; Chua et al., 2009; Hiebl \& Mayrleitner, 2019) and (5) the design of formal human resource systems (De Kok, Thurik \& Uhlaner, 2006; TsuiAuch, 2004; Dyer, 2006; Madison et al., 2018). 


\section{Benefits of professionalization}

"The issue of professionalizing a family business is one that most, if not all leaders of growing family firms must grapple with at some point" (Dyer, 1989, p. 233). Many authors argue that family businesses need to professionalize in order to weaken their traditional impediments like opportunism, altruism, or nepotism (Dyer 1989; Basco, 2013). Others claim that the reason for professionalization is the lack of formal governance mechanisms and professional managers (Martínez, Stöhr, \& Quiroga, 2007; Sciascia \& Mazzola, 2008; Randøy et al., 2009; Dekker et al., 2013).

Professionalization can lead to financial benefits and competitive advantage in the case of family firms. The research of Schulze, Lubatkin, Dino, and Buchholtz (2001) on a sample of 1376 U.S. family-owned companies found that family firms that developed formal corporate governance mechanisms performed better financially than those who have not developed such systems. Anderson and Reeb (2003) and Martínez, Stöhr, and Quiroga (2007) both found, comparing family and non-family firms listed on the stock market, that family firms outperform non-family firms when they professionalize their management and develop formal governance mechanisms.

According to Dyer (1989), there are three main reasons why a family firm could professionalize:

a) The family's lack of management knowledge: such knowledge may be marketing, finance, or accounting knowledge. As the business grows, it is unlikely that they will be able to delegate family members with the right skills for each key position so that they will need outside help.

b) Changing the family business's norms and values: unconditional love and worry within the family is often at odds with profitability and efficiency.

c) Preparation for the transfer of leadership, succession: in case of the founder's retirement who feels no one could take over the business, hiring an external CEO could be necessary.

As environmental and organizational complexity increases, it becomes necessary for a company to formalize responsibilities, especially the transfer of roles and duties for various activities to the managers responsible for each organizational department (Gnan \& Songini, 2003). In some cases, professionalization can be seen by family businesses as a strategic opportunity to gain a lasting competitive advantage (Chua, Chrisman \& Bergiel, 2009; Fang, Memili, Chrisman, \& Welsh, 2012) and to access resources more easily, improve their productivity and to embark on a growth path (Craig \& Moores, 2005; Chua et al., 2009). As a result of the professionalization process, diverse perspectives brought 
in by external or internal professional managers can help family businesses seize opportunities while managing the risks of the dynamic environment around them, paving the way for better strategy-making (Polat, 2020).

\section{Difficulties of professionalization}

Family businesses are often reluctant to hire an external - non-family - manager, given that many family business owners focus on maintaining control over their own business (Vandekerkhof, Steijvers, Voordeckers, \& Hendriks, 2011; Dekker et al., 2013; De Massis, Di Minin, \& Frattini, 2015). Preserving the family's socio-emotional wealth (SEW) and reducing agency costs may also play an important role in a family's reluctance to involve an external manager (De Massis et al., 2015; Fang, Memili, Chrisman, \& Penney, 2017). Involving an outside leader independent of the family is likely to reduce the family's control over strategic decisions (Gomez-Meija, Cruz, Berrone, \& De Castro, 2011). Even if family businesses are ready for the challenges of professionalization and choose to do it so through hiring an external manager, there may be a lack of adequate financial resources to attract and retain skilled professionals (Songini, 2006; Tsao, Chen, Lin, \& Hyde, 2009) and recognize the need to implement necessary structural changes within the company (Songini, 2006).

There are also cases where the founders themselves are the barrier to professionalization, not recognized in time (Németh \& Németh, 2018). The founder and the successor's goals and ideas may be common, but many conflicts may arise during implementation. Another boundary to professionalization is that family firms prefer to use informal control systems and processes (Daily \& Dollinger, 1992; Jorissen, Laveren, Martens, \& Reheul, 2002; Songini, Morelli, Gnan, \& Vola, 2015; Diéguez-Soto, Duréndez, García-Pérez-de-Lema, \& Ruiz-Palomo, 2016) because strong interpersonal relationships serve as a control mechanism and family members are reluctant to control, evaluate, and sanction each other (Dyer, 2006). 


\section{Research method}

This paper is based on the standard methodology of a literature review. A thorough literature review provides insights into the current issues of the research topic (Hart, 2018), pointing out what is new at the international level in academic circles. By searching for and reviewing the literature on the case, it is possible to summarize the topic and form research questions (Rowley \& Slack, 2004). Besides, a literature review also provides a factual basis for subsequent empirical research, revealing unknown areas to be explored (Webster \& Watson, 2002). A literature review is a step after collecting literature: the analysis, critical evaluation, and synthesis of journal articles and other scholarly works filtered and selected according to specific criteria and a given research question (Hart, 2018).

I applied a mixed methodology (Grant \& Booth, 2009) to search and process the literature. Firstly, I used a search by keywords, and then I used a targeted search based on the reference lists and the so-called snowball method. Based on my prior knowledge of the keyword search, I filtered for journal articles in the EBSCO, JSTORE, and Science Direct databases that have been published in the last twenty years and whose title, keywords, or abstracts included "family business" or "family firm", and the terms "professionalization" or "professional management" or "performance". From the obtained results, I filtered out the publications published in other non-business and management disciplines. After that, I selected based on additional professional and content aspects: I filtered out the studies that were not relevant to the examined topic based on their title and abstract. In my research, I studied a total of more than seventy related journals or articles published in handbooks. Some publications outside the period under study will also appear in my study. I have included them in the literature review due to their significance, more profound presentation, description of the topic, and the high level of their citation. 


\section{Results}

\section{The multidimensional model of professionalization}

The literature can be categorized into two main categories: content and process. There are a various number of articles whose authors define what professionalization is and deal with its content, what does professionalization mean, and what are the elements of it (e.g., Stewart \& Hitt, 2012; Dekker at al., 2013; Dekker et al., 2015), and those who deal with its drivers, and have a process point of view (e.g., Zhang \& Ma, 2009; Howorth et al., 2016). In this paper I focus on the content aspect and present the main results in that perspective.

Dekker and her colleagues (2013) wanted to examine the degree of professionalization in the case of family businesses. However, the theories set up so far did not define how professionalization could be measured. They concluded an exploratory factor analysis and identified five important elements as dimensions of professionalization: (1) the first is financial control systems, the extent to which family companies use elements such as budgeting, financial planning, and built performance measurement systems; 2) second is the participation of non-family members in corporate governance systems (Gedajlovic, Lubatkin, \& Schulze, 2004; Öktem \& Üsdiken, 2010), the ratio of family or non-family members, (3) human resource control systems as recruitment, selection and remuneration systems, (4) decentralization of responsibilities as delegation of decision making, and (5) top-level activeness, how actively the company's top management communicates its goals and values. To validate the identified dimensions, quantitative research was conducted on a 532-item Belgian family sample of small and medium-sized enterprises and using cluster analysis; the firms were classified into four clusters (Dekker et al., 2013).

In addition to contributing to the literature on professionalization related to family businesses, Dekker and her colleagues make findings applicable in practice. The professionalization of family businesses is necessary by hiring an external manager, but it is not sufficient and is not the only viable path. While retaining family leadership, a family business can achieve a higher level of professionalization through other dimensions, such as the design of formal corporate governance systems, the implementation of formal control systems, thus ensuring the objectivity and transparency of the company's operations.

Their research two years later, carried out on 523 Belgian family businesses, confirmed the dimensions identified. Their study concluded that if a family business wants to positively influence its performance through professionalization, it should reduce family 
participation in corporate governance systems and increase the use of formal human resource control systems to help the family overcome nepotism or family altruism (Dekker et al., 2015).

\section{Complementing the multidimensional model of professionalization}

Among the publications of recent years, we find more than one that acknowledged Dekker et al.'s (2013) definition of professionalization and its multidimensional nature but made further additions. In his study, Basco (2013) proposed to include two new elements related to the concept, (1) the orientation of decision-making and (2) the consequences of professionalization. In his argument, he points out that the orientation of decision-making needs to be included because the management dimension of professionalization must also take into account the relationship between family and business, as it is related to decisionmaking. The consequences of professionalization must be taken into account in the light of the extent to which the family successfully achieves its goals and tasks. This view is reinforced by Gimeno and Parada (2014) that professionalization is closely linked to decision-making, where senior executives face poorly structured problems and an uncertain dynamic environment in which they have to make decisions competing with time under tremendous pressure.

In their research on 249 Portuguese family businesses, Camfield and Franco (2019) confirmed the dimensions of professionalization defined by Dekker et al. and suggested adding three new dimensions: (6) family involvement in management systems in parallel with previous research (Dyer, 1989; Gnan \& Songini, 2003; Hall \& Nordqvist, 2008; Chrisman, Chua, Le Breton - Miller, Miller, \& Steier, 2018) the professionalization of a business does not begin with the recruitment of an external, professional manager, but with the training of family members who can also acquire the necessary skills, (7) the cultural aspects that are at least as important as financial aspects (Gnan \& Songini, 2009; Waldkirch et al., 2017; Polat, 2020) and (8) organizational development thus complementing the professionalization of family businesses into an eight-dimensional multidimensional model.

The following table summarizes the theoretical and practical dimensions of professionalization with the additions mentioned earlier (Dyer, 1989; Songini, 2006; Dekker et al., 2013; Basco, 2013; Gimeno \& Parada, 2014; Camfield \& Franco, 2019) and new explorations (Suess, 2014; Madison et al., 2018; Polat, 2020). The supplemented model incorporates the content dimensions of professionalization explored so far based on theoretical and empirical analyses. The previous multidimensional models deal with too 
many factors and mix content and process topics. Besides, they show a bias towards either personal or material factors. The innovation in this model is:

a) Clearly defined, only includes content factors,

b) Simplified because it classifies the dimensions into four types

c) Balanced, as soft and hard factors have the same emphasis.

Table 1 summarizes the main findings of the types and dimensions of professionalization. It contains the personal, management, and organizational conditions in one place and treat the cultural aspect separately as it is the mixture of the previous two. It contains not only the business but the borderline family factors as well.

Table 1: The types and dimensions of professionalization in family firms

\begin{tabular}{|c|c|c|}
\hline $\begin{array}{l}\text { Type of } \\
\text { professionalization }\end{array}$ & Dimensions & Authors \\
\hline \multirow{6}{*}{$\begin{array}{l}\text { Professionalization of } \\
\text { members, boards, and } \\
\text { employees }\end{array}$} & Professionalization of board & Dekker et al., 2013 \\
\hline & Professionalization of managers & Dekker et al., 2013 \\
\hline & Non-family involvement in management & Dekker et al., 2013 \\
\hline & Delegation and decentralization of authority & Dyer 1989; Polat, 2020 Dyer, \\
\hline & Training of non-family managers & 1989; Polat, 2020 \\
\hline & Professionalizing non-family employees & Dyer, 1989 \\
\hline \multirow{7}{*}{$\begin{array}{l}\text { Professionalization of } \\
\text { organizational } \\
\text { structure, processes, } \\
\text { and operations }\end{array}$} & Strategic planning & Songini, 2006; Polat, 2020 \\
\hline & Formal organizational and operational structure & Polat, 2020; \\
\hline & Formal control mechanisms & Songini, 2006; Dekker et al., \\
\hline & Organizational development & 2013 Camfield \& Franco, \\
\hline & The orientation of decision making & 2019 \\
\hline & Formal human-resource systems like compensation & $\begin{array}{l}\text { Basco, 2013; Gimeno \& } \\
\text { Parada, } 2014\end{array}$ \\
\hline & $\begin{array}{l}\text { incentive systems and performance appraisal } \\
\text { systems }\end{array}$ & Madison et al., 2018 \\
\hline \multirow{4}{*}{$\begin{array}{l}\text { Professionalization of } \\
\text { work environment and } \\
\text { organizational culture }\end{array}$} & Cultural aspects: & \multirow{4}{*}{$\begin{array}{c}\text { based on Camfield \& Franco, } \\
2019 ; \\
\text { Polat, } 2020\end{array}$} \\
\hline & Organizational culture & \\
\hline & Business culture & \\
\hline & Technology culture & \\
\hline \multirow{2}{*}{$\begin{array}{l}\text { Professionalization of } \\
\text { family's relationship } \\
\text { with the business }\end{array}$} & $\begin{array}{l}\text { Effective governance mechanisms like a family } \\
\text { council and a family constitution }\end{array}$ & $\begin{array}{l}\text { Dekker et al., 2013; Suess, } \\
\qquad 2014\end{array}$ \\
\hline & Succession plan & Polat, 2020 \\
\hline
\end{tabular}

Source: Own editing based on Polat (2020) 


\section{Discussion and recommendations}

We have seen that professionalization of family businesses is a complex, multidimensional phenomenon that cannot be identified solely by the family, reducing its participation in corporate governance by hiring external, non-family leaders. In the literature, professionalization as a concept has gone through a dynamic development, with the initial identification of only one external manager recruitment (Klein \& Bell, 2007; Zhang \& Ma, 2009) being replaced by a multidimensional extension of the phenomenon (Dekker et al., 2013; Gimeno \& Parada, 2014; Dekker et al., 2015; Camfield \& Franco, 2019; Polat, 2020). In my study, based on the most important works of the last twenty years of international literature, I presented the professionalization of family firms, the initial meaning of the concept, its expansion, and the impediments and impetuses of professionalization for family firms. Based on the relevant literature, I summarized in a table at the end of my study which are the main dimensions of professionalization.

There has not been a comprehensive literature review on the professionalization of family businesses before. Although my paper is not intended to detail the publications cited in full, I trust that by presenting and reviewing the phenomenon and providing a new, clearly defined, presentation of the dimensions and types of family firm's professionalization, I can provide a comprehensive picture for practicing leaders and professionals and all readers interested in family businesses. 


\section{References}

Anderson, R. C., \& Reeb, D. M. (2003). Founding-Family Ownership and Firm Performance: Evidence from the S\&P 500. The Journal of Finance, 1301-1328. https://doi.org/10.1111/1540-6261.00567

Basco, R. (2013). The family's effect on family firm performance: A model testing the demographic and essence approaches. Journal of Family Business Strategy, 4(1), 42-66. https://doi.org/10.1016/j.jfbs.2012.12.003

Brumana, M., Cassia, L., De Massis, A., Cruz, A. D., \& Minola, T. (2015). Transgenerational professionalization of family firms: the role of next generation leaders. In P. Sharma, N. Auletta, R.-L. DeWitt, M. J. Parada, \& M. Yusof, Developing Next Generation Leaders for Transgenerational Entrepreneurial Family Enterprises (pp. 99-126). Cheltenham: Edward Elgar Publishing Limited.

Camfield, C., \& Franco, M. (2019). Professionalisation of the Family Firm and Its Relationship with Personal Values. The Journal of Entrepreneurship, 28(1), 144-288. https://doi.org/10.1177/0971355718810291

Chandler, A. (1977). The visible hand: the managerial revolution in American business. Cambridge, Mass.:Belknap.

Chittoor, R., \& Das, R. (2007). Professionalization of Management and Succession Performance-A Vital Linkage. Family Business Review, 20(1), 65-79. https://doi.org/10.1111/j.1741-6248.2007.00084.x

Chrisman, J. J., Chua, J. H., De Massis, A., Minola, T., \& Vismara, S. (2016). Management processes and strategy execution in family firms: from "what" to "how". Small Business Economics, 47, 719-734. https://doi.org/10.1007/s11187-016-9772-3

Chrisman, J. J., Chua, J. H., Le Breton - Miller, I., Miller, D., \& Steier, L. P. (2018). Governance Mechanisms and Family Firms. Entreprenenurship Theory and Practice, 42(2), 171-186. https://doi.org/10.1177/1042258717748650

Chua, J. H., Chrisman, J. J., \& Bergiel, E. B. (2009). An Agency Theoretic Analysis of the Professionalized Family Firm. Entrepreneurship Theory and Practice, 355-372. https://doi.org/10.1111/j.1540-6520.2009.00294.x

Craig, J., \& Moores, K. (2005). Balanced Scorecards to Drive the Strategic Planning of Family Firms. Family Business Review, 105-122. https://doi.org/10.1111/j.17416248.2005.00035.x

Daily, C. M., \& Dollinger, M. J. (1992). An Empirical Examination of Ownership Structure in Family and Professionally Managed Firms. Family Business Review, 117-136.

De Kok, J.M.P., Uhlaner, L.M.\& Thurik, A.R. (2006), Professional HRM Practices in Family Owned-Managed Enterprises. Journal of Small Business Management, 44, 441-460. https://doi.org/10.1111/j.1540-627X.2006.00181.x

De Massis, A., Di Minin, A., \& Frattini, F. (2015). Family-Driven Innovation: Resolving the Paradox in Family Firms. California Management Review, 58(I.), 5-19. https://doi.org/10.1525/cmr.2015.58.1.5 
Dekker, J. C., Lybaert, N., Steijvers, T., Depaire, B., \& Mercken, R. (2013). Family Firm Types Based on the Professionalization Construct: Exploratory Research. Family Business Review, 81-99. https://doi.org/10.1177/0894486512445614

Dekker, J., Lybaert, N., Steijvers, T., \& Depaire, B. (2015). The Effect of Family Business Professionalization as a Multidimensional Construct on Firm Performance. Journal of Small Business Management, 53(2), 516-538. https://doi.org/10.1111/jsbm.12082

Diéguez-Soto, J., Duréndez, A., García-Pérez-de-Lema, D., \& Ruiz-Palomo, D. (2016). Technological, management, and persistent innovation in small and medium family firms: The influence of professionalism. Canadian Journal of Administrative Sciences, 33, 332-336. https://doi.org/10.1002/cjas.1404

Dyer, W. J. (1989). Integrating Professional Management into a Family Owned Business. Family Business Review, 221-236.

Dyer, W. J. (2006). Examining the "Family Effect" on Firm Performance. Family Business Review, 19(4) 253-273. https://doi.org/10.1111/j.1741-6248.2006.00074.x

Fang, H., Memili, E., Chrisman, J. J., \& Penney, C. (2017). Industry and Information Asymmetry: The Case of the Employment of Non-Family Managers in Small and Medium-Sized Family Firms. Journal of Small Business Management, 55(4), 632-648. https://doi.org/10.1111/jsbm.12267

Fang, H., Memili, E., Chrisman, J. J., \& Welsh, D. H. (2012). Family Firm's Professionalization: Institutional Theory and Resource-Based View Perspectives. Small Business Institute Journal, 8(2), 12-34.

Flamholtz, E. G., \& Randle, Y. (2007). Growing Pain - Transitioning from an Entrepreneurship to a Professionally Managed Firm. San Fransisco: Jossy-Bass.

Gedajlovic, E., Lubatkin, M. H., \& Schulze, W. S. (2004). Crossing the Threshold from Founder Management To Professional Management: A Governance Perspective. Journal of Management Studies, 899-912. https://doi.org/10.1111/j.1467-6486.2004.00459.x

Gimeno, A., \& Parada, M. J. (2014). Professionalization of the family business: decision-making domains. In P. Sharma, P. Sieger, R. S. Nason, A. C. González L., \& K. Ramachandran, Exploring Transgenerational Entrepreneurship - The Role of Resources and Capabilities (pp. 42-62). Cheltenham: Edward Elgar Publishing Limited.

Gnan, L., \& Songini, L. (2003). The Professionalization of Family Firms: The Role of Agency Cost Control Mechanisms. FBN Proceedings.

Gnan, L., \& Songini, L. (2009). Women, Glass Ceiling, and Professionalization in Family SMEs. A Missed Link. Journal of Enterprising Culture, 497-525. https://doi.org/10.1142/s0218495809000461

Gomez-Meija, L. R., Cruz, C., Berrone, P., \& De Castro, J. (2011). The Bind that Ties: Socioemotional Wealth Preservation in Family Firms. The Academy of Management Annals, 5(1), 653-707. https://doi.org/10.5465/19416520.2011.593320

Grant, M. J., \& Booth, A. (2009). A typology of reviews: An analysis of 14 review types and associated methodologies. Health Information and Libraries Journal, 26(2), 91-108. https://doi.org/10.1111/j.1471-1842.2009.00848.x 
Hall, A., \& Nordqvist, M. (2008). Professional Management in Family Businesses: Toward an Extended Understanding. Family Business Review 21(1), 51-69. https://doi.org/10.1111/j.1741-6248.2007.00109.x

Hart, C. (2018). Doing a Literature Review: Releasing the Research Imagination (SAGE Study Skills Series). London: Sage Publications.

Hiebl, M. R., \& Mayrleitner, B. (2019). Professionalization of management accounting in family firms: the impact of family members. Review of Managerial Science, 13(5), 1037-1068. https://doi.org/10.1007/s11846-017-0274-8

Howorth, C., Wright, M., Westhead, P., \& Allcock, D. (2016). Company metamorphosis: professionalization waves, family firms and management buyouts. Small Business Economics, 47(3), 803-817. https://doi.org/10.1007/s11187-016-9761-6

Jorissen, A., Laveren, E., Martens, R., \& Reheul, A.-M. (2002). Differences Between Family and Non-Family Firms - The impact of different research samples with increasing elimination of demographic sample differences. Working Papers.

Klein, S. B., \& Bell, F.-A. (2007). Non-Family Executives in Family Businesses - A Literature Review. Electronic Journal of Family Business Studies 1(1), 19-37.

Lin, S.-h., \& Hu, S.-y. (2007). A Family Member or Professional Management? The Choice of a CEO and Its Impact on Performance. Corporate Governance: An International Review, 15, 1348-1362. https://doi.org/10.1111/j.1467-8683.2007.00650.x

Madison, K., Daspit, J. J., Turner, K., \& Kellermans, F. W. (2018). Family firm human resource practices: Investigating the effects of professionalization and bifurcation bias on performance. Journal of Business Research, 84, 327-336. https://doi.org/10.1016/j.jbusres.2017.06.021

Martínez, J. I., Stöhr, B. S., \& Quiroga, F. B. (2007). Family Ownership and Firm Performance: Evidence From Public Companies in Chile. Family Business Review 20(2), 83-94. https://doi.org/10.1111/j.1741-6248.2007.00087.x

Németh, K., \& Németh, S. (2018). Professzionalizálódó családi vállalkozások Magyarországon. Prosperitas Vol. V., (24-47.). https://doi.org/10.31570/prosp_2018_03_2

Öktem, Ö. Y., \& Üsdiken, B. (2010). Contingencies Versus External Pressure: Professionalization in Boards of Firms Affiliated to Family Business Groups in LateIndustrializing Countries. British Journal Of Management, 21(1), 115-130. https://doi.org/10.1111/j.1467-8551.2009.00663.x

Polat, G. (2020). Advancing the multidimensional approach to family business professionalization. Journal of Family Business Management. https://doi.org/10.1108/jfbm-03-2020-0020

Randøy, T., Dibrell, C., \& Craig, J. B. (2009). Founding Family Leadership and Industry Profitability. Small Business Economics, 32(4), 397-407. https://doi.org/10.1007/s11187008-9099-9

Rowley, J. \& Slack, F. (2004). Conducting a literature review. Management Research News, $27(6), 31-39$. 
Schulze, W. S., Lubatkin, M. H., Dino, R. N., \& Buchholtz, A. K. (2001). Agency Relationships in Family Firms: Theory and Evidence. Organization Science, 12(2), 99-116. https://doi.org/10.1287/orsc.12.2.99.10114

Sciascia, S., \& Mazzola, P. (2008). Family Involvement in Ownership and Management: Exploring Nonlinear Effects on Performance. Family Business Review, 21(4), 331-345. https://doi.org/10.1177/08944865080210040105

Songini, L. (2006). The professionalization of family firms: theory and practice. In P. Z. Poutziouris, K. X. Smyrnios, \& S. B. Klein, Handbook of Research on Family Business. Cheltenham: Edward Elgar Publishing Limited. https://doi.org/10.4337/9781847204394.00026

Songini, L., Morelli, C., Gnan, L., \& Vola, P. (2015). The Why and How of Managerializati on of Family Businesses: Evidences from Italy. Rivista Piccola Impresa/Small Business, 86118.

Suess, J. (2014). Family governance - Literature review and the development of a conceptual model. Journal of Family Business Strategy, 5(2), 138-155. https://doi.org/10.1016/j.jfbs.2014.02.001

Stewart, A., \& Hitt, MA. (2012). Why Can't a Family Business Be More Like a Nonfamily Business?: Modes of Professionalization in Family Firms. Family Business Review, 25(1), 58-86. doi:10.1177/0894486511421665

Tsao, C.-W., Chen, S.-J., Lin, C.-S., \& Hyde, W. (2009). Founding-Family Ownership and Firm Performance: The Role of High-Performance Work Systems. Family Business Review 22(4), 319-332. https://doi.org/10.1177/0894486509339322

Tsui-Auch, L. (2004). The Professionally Managed Family-ruled Enterprise: Ethnic Chinese Business in Singapore. Journal of Management Studies, 41(4), 693-723. https://doi.org/10.1111/j.1467-6486.2004.00450.x

Vandekerkhof, P., Steijvers, T., Voordeckers, W., \& Hendriks, W. (2011). Professionalization of TMT in Private Family Firms - the Danger of Institutionalism. Hasselt, Belgium.

Waldkirch, M., Melin, L., \& Nordqvist, M. (2017). When the Cure Turns Counterproductive: Parallel Professionalization In Family Firms. In Academy of Management Annual Meeting Proceedings. Academy of Management. https://doi.org/10.5465/ambpp.2017.50

Webster, J., \& Watson, R. T. (2002). Analyzing the Past to Prepare for the Future: Writing a Literature Review. MIS Quarterly, 26(2), 13-23.

Zhang, J., \& Ma, H. (2009). Adoption of professional management in Chinese family business: A multilevel analysis of impetuses and impediments. Asia Pacific Journal of Management, 26(1), 119-139. https://doi.org/10.1007/s10490-008-9099-y 


\title{
Entry Dynamics of Startup Companies and the Drivers of Their Growth in the Nascent Blockchain Industry
}

\author{
VIKTORIIA SEMENOVA* \\ *Corvinus University of Budapest, Institute for the Development of Enterprises; \\ viktoriia.semenova@stud.uni-corvinus.hu
}

DOI: $10.14267 / 978-963-503-867-1 \_13$

\begin{abstract}
The purpose of the paper is to discuss the characteristics of the blockchain (hereinafter "BT") industry and factors that affect the success of BT-based startup companies. Due to the novelty of BT technology, the current period of its development is associated with a high number of newly emerging firms that are predominant in the BT industry. The study seeks to address the two main research questions: What are the key characteristics of the BT industry? What are the factors that determine the success of BT-based companies? To answer these questions, the method of the systematic literature review was applied. The discussion of the reviewed 43 publications led to the classification of literature sources into six categories, including research streams on BT in the contexts of entrepreneurial finance, institutional theory, digital and social entrepreneurship, business models, and international business. The results suggested that the early success of the BT-based startups' entry and growth related to the supportive entrepreneurial environments, a greater degree of regulatory clarity, the formation of strategic associations, entrepreneur's active engagement in sharing expertise and shaping the regulations and standards, a profound business model, and experienced management. It is recommended that policymakers should support the creation of new ventures and the transfer of knowledge about BT. Managers of established companies should cooperate with startups to adopt BT applications into their business models. Future research should be based on empirical research studies, namely cluster analysis, to identify the determinants of success/failure of BT-enabled startup firms. This paper contributes to BT research and the literature on the emergence of new industrial fields and ventures.
\end{abstract}

Keywords: blockchain industry, venture, start-up

Funding: The present publication is the outcome of the project "From Talent to Young Researcher project aimed at activities supporting the research career model in higher education," identifier EFOP3.6.3-VEKOP-16-2017-00007 co-supported by the European Union, Hungary, and the European Social Fund. The author would like to thank the National Bank of Hungary for the financial support under the Research Excellence Award. 


\section{Introduction}

The period of technology emergence is commonly associated with newly created firms. According to technology life-cycle theories, the preferred mode of technology exploitation is new firms, provided that technology is novel, and a market tends toward segmentation (Shane, 2001). Audretsch (2002) suggests that small firms serve as agents of change and creators of innovations by ensuring an essential source of new ideas and experimentation and being able to adopt new technologies faster than larger enterprises. The development of blockchain (hereinafter referred to as: BT) technologies has resulted in the creation of a variety of companies, products, and services as well as the formation of a BT ecosystem that is a dynamic space with many new entries and exits. The technology of BT has become an industry in its own right (Liu, 2020). The technology has triggered innovation processes by creating new capabilities for entrepreneurs and reshaping the nature of innovation and entrepreneurship (Chen, 2018; Massey et al., 2017).

The purpose of this study is to analyse the BT-related ventures and factors facilitating the creation and growth of such firms in the nascent BT industry. This study seeks to address two main research questions: (1) What are the key characteristics of the BT industry? (2) What are the factors that determine the success of BT-based companies? To answer these questions, a systematic literature review was conducted. The discussion of the reviewed 43 papers led to their classification into six categories and enabled answering to the formulated questions. This paper contributes to the literature on the emergence of new industries (Colombelli et al., 2014; Giarratana, 2004; Krafft et al., 2014), the study of new venture formation (Shane, 2001), and the BT research that is still in its infancy (Kher et al., 2020).

The remainder of the paper is organised as follows. In the theoretical part, the formation of new industries and guidelines for analysing new venture creation are discussed. Thirdly, it is followed by a method section describing how this conceptual research was carried out. In the result part, the findings of this research were analysed based on previous research works and presented in a tabular form. Finally, discussion and concluding remarks, followed by theoretical and managerial implications and future research directions are outlined. 


\section{Theoretical background on the birth of new industries and ventures}

The process of new industries formation is shaped by the dynamics of knowledge creation in the geographic and technological space as well as institutional setting. There are a number of forces that drive the formation of industry, including the creation of new innovative firms, mobility of labour force enabling knowledge transfer and exploitation in novel contexts, establishment and evolution of network linkages (Krafft et al., 2014). The competencies which are already developed by local agents ensure the successful emergence of new activities. Colombelli et al. (2014) affirmed that the dynamic was more evident when such activities were based on brand new technologies.

In order to analyse new firms' creation in the process of shaping industries, Gartner (1985) and Giarratana (2004) proposed some guidelines. According to them, three main areas are required to assess: the environment, the new product or process, and the entrepreneurs as well as their connection with each other. First, the organisational forms of start-ups make them critical in opening new markets as they are better adapted to young turbulent environments (Giarratana, 2004). However, Jáki et al. (2019) state that all start-ups need a supportive ecosystem for rapid development and easy access to global markets. Entrepreneur-friendly ecosystems also have a huge positive influence on firm entry and growth (Gartner, 1985). So, the specific features of the environments should be considered while analysing the conditions underpinning the emergence of new industries and firms. Moreover, the formation of new industry shows cross-country differences due to various initial institutional and technological regimes (Casper \& Whitley, 2004).

Secondly, the rising demand in the digital sphere causes an increase in the complexity and the spectrum of different products. This process provides an opportunity for smaller companies and start-ups to exploit these specific needs and challenge market leaders in well-defined niche areas by creating new products and processes. Thirdly, in the earlier periods of the firm existence, its survival primarily depends on the founder's abilities and competencies. In exploiting the same business opportunities, entrepreneurs follow different approaches. This results in a high degree of heterogeneity among the firms (Gartner, 1985; Giarratana, 2004) whose most important drivers of growth are specialisation in a particular niche, the introduction of a distinguished innovative product, and international expansion. Thus, this paper is devoted to studying the technology of BT and the concomitant BT industry as well as the characteristics of BT-enabled startup firms. 


\section{Methodology}

The systematic review methodology was adopted and articles were searched in the Web of Science (WoS) citation database to address the research objective and questions. Firstly, the method of the systematic literature review was chosen because it could generate valuable information and identify practical implementation and conceptual frameworks from available resources (Hart, 1998). Secondly, I limited the search of the papers to one database as the WoS was considered a significant scientific instrument across countries and knowledge domains (Li et al., 2018). Besides, the WoS and Scopus databases provide fairly similar results (Harzing \& Alakangas, 2016).

As of January 2021, a combination of the following search strings - "blockchain" AND "entrepreneurship", "blockchain" AND "new venture", "blockchain" AND "startup" - resulted in 47, 27, and 52 papers, respectively. After screening title, keywords, abstract, and content, several papers with the following parameters were excluded: papers without fulltext availability, papers that were duplicates, editorial insights, papers with technical description and not relevant to the research topic (e.g., Fintech), papers that had some other meaning than BT used in computer science (e.g., smart contracts, Bitcoin). In a few papers, the term 'blockchain' was mentioned in the title but the technology was not described or somehow presented in the works.

I used the SCImago journal ranking (SJR) to include high-quality, peer-reviewed journals, though the conference papers and articles from lower-ranking journals were also added to ensure the relevance and completeness of the review. The final sample comprises 43 publications on the most researched aspects of BT, though I do not state that the set of selected papers is exhaustive. Most of the reviewed articles were primarily published in such high-impact Q1 journals as Business Horizons (3 articles), Small Business Economics (3 articles), Journal of Business Research (2 papers), Research Policy (2 papers), Journal of Business Venturing, Foundations and Trends in Entrepreneurship, Technological Forecasting and Social Change, and others. 3 proceedings papers and 3 articles from journals not presented in the SCImago rank were also included in the sample. 


\section{Results}

This section discusses the results of the literature review. An examination of the available papers demonstrates the nascent stage of academic interest in the field of new technology (i.e. BT). The topic has recently received attention because the majority of papers are from the last three years (2018 with 8 papers; 2019 - 12 papers; 2020 - 21 papers) and 1 paper from 2017 and 2016. This indicates the novelty of the topic and the reason why a comprehensive analysis on BT-based firms has not been elaborated yet. This finding is consistent with Chalmers et al. (2019) notice about a small number of studies exploring entrepreneurship and BT. Meanwhile, the analysis of existing articles has shown that the papers can be divided into the following six categories (see Table 1):

(1) BT and Entrepreneurial finance - 22 papers.

This category contains papers that were mainly conducted in the context of entrepreneurial finance. Ahluwalia et al. (2020) conducted the first research on explaining startup finance and BT technologies in the framework of transaction costs economics. In the field of entrepreneurial finance, the information asymmetries between an investor and an entrepreneur and transaction costs associated with the financing of startup companies are high. In this regard, BT is claimed to mitigate those issues by reducing costs and present with alternatives to such activities. The ability of BT to tokenise and decentralise money and a broad range of scarce assets beyond currencies led to the emergence of a new way of fundraising - initial coin offerings (ICOs) - that allows raising funds directly from investors across the globe (Chen, 2018; Jackson, 2017). The majority of entrepreneurship research examines ICOs as a novel form of entrepreneurial finance for highly innovative BT ventures (Chen, 2019; Kher et al., 2020). Schückes and Gutmann (2020) enriched the literature on entrepreneurial finance by advancing the understanding of ICOs and the literature on entrepreneurial decision making by explaining the entrepreneurs' funding choice.

(2) BT as an external enabler/Digital entrepreneurship - 6 papers.

Insofar as a growing body of entrepreneurship literature has focused on the role of digital technologies in entrepreneurial processes and practices (Nambisan, 2017), this category covers papers on BT as a digital enabler and entrepreneurial activities for developing novel innovation systems. Mickiewicz and Rebmann (2020) indicated that BT enabled entrepreneurs to create a new form of distributed trust between strangers. Unalan and Ozcan (2020) stated about the increased distribution of networks and collaboration and democratisation of entrepreneurship by the new funding landscape. The study of Chalmers et al. (2019) on entrepreneurial firms using BT for developing new venture ideas in the 
music industry provided a novel view on intersections between external enabler theory and digital entrepreneurship.

(3) BT and Institutional theory/economics/cryptoeconomics - 5 papers.

In this category, papers mostly examine the institutional context of the entrepreneurial discovery of BT applications. Allen et al. (2020) state that BT infrastructure provides new avenues for entrepreneurship and innovation amongst previously unforeseen domains of economic activities across firms, industries, and states. The technology has driven a new process of institutional discovery that challenges government hegemonies. BT has also expanded the scope for entrepreneurial activities in monetary institutions (Berg et al., 2020). According to Allen (2019), BT policy enables entrepreneurs to test and trial their ideas in markets, so there is a need for economic and political reform of various regulatory barriers that inhibit entrepreneurial actions.

(4) BT and Social entrepreneurship - 3 papers.

A few publications are linked to the topic of social entrepreneurship. Jain and Simha (2018) explained how BT could be adapted for the field of charitable donations and social entrepreneurship by introducing a distributed ledger application for the world of citizen philanthropy and social entrepreneurship. Gogan et al. (2020) enriched a small stream of studies on IT-enabled hybrid social enterprises and explored how a social entrepreneur saw an opportunity and built a BT-based platform.

(5) BT and Business models -6 papers.

In this category, the findings of the presented papers show how BT can create business value and contribute to the technology-driven blockchain literature. Morkunas et al. (2019) and Weking et al. (2019) noted the scarcity of research in relation to the impact of blockchain on business models, creation, and delivery of value. Park and Sung (2020) pointed to a lack of studies on analysing the business feasibility for value creation and revenue generation from the eyes of a technology entrepreneur. Meanwhile, research on business model promotes an understanding of the impact of BT on existing and new business models. According to Kher et al. (2020), broader research on new business models of startup firms and technology adoption is critical for the development of this field.

(6) BT and Internationalisation of firm - 1 paper.

Zalan (2018) described a new phenomenon in international business, that is an increasing number of technology-based born global start-ups with distinctive characteristics, on the 
example of BT-enabled ventures which are originally "born global" due to characteristics of the technology.

Table 1: Classification and summary of the reviewed papers*

\begin{tabular}{|c|c|c|}
\hline Author(s) / Topic & Research type & Findings \\
\hline \multicolumn{3}{|l|}{ BT \& Entrepreneurial finance } \\
\hline $\begin{array}{l}\text { Ahluwalia, Mahto, \& Guerrero } \\
\text { (2020) } \\
\text { Blockchain technology and } \\
\text { startup financing: A transaction } \\
\text { cost economics perspective }\end{array}$ & $\begin{array}{c}\text { Conceptual } \\
\text { paper }\end{array}$ & $\begin{array}{l}\text { BT can significantly reduce the transaction costs for } \\
\text { stakeholders in the entrepreneurial ecosystem, such as } \\
\text { entrepreneurs, angels, and VCs. }\end{array}$ \\
\hline Chen (2018) & Conceptual & BT tokens may democratise \\
\hline $\begin{array}{l}\text { Blockchain tokens and the } \\
\text { potential democratisation of } \\
\text { entrepreneurship and innovation }\end{array}$ & paper & $\begin{array}{l}\text { - entrepreneurship by giving entrepreneurs new ways to } \\
\text { raise funds and engage stakeholders, } \\
\text { - innovation by giving innovators a new way to develop, } \\
\text { deploy, and diffuse decentralised applications. }\end{array}$ \\
\hline $\begin{array}{l}\text { Park, Shin, \& Choy (2020) } \\
\text { Early mover (dis)advantages } \\
\text { and knowledge spillover effects } \\
\text { on blockchain startups' funding } \\
\text { and innovation performance }\end{array}$ & $\begin{array}{l}\text { Empirical } \\
\text { research study } \\
\text { / Quantitative }\end{array}$ & $\begin{array}{l}\text { Early entry allows founders of BT startups to gain early } \\
\text { mover advantages, especially regarding funding } \\
\text { attraction from venture capitals. Disadvantages posed } \\
\text { for late comer start-ups may be alleviated by pursuing } \\
\text { external activities such as conference participation and } \\
\text { presentation. }\end{array}$ \\
\hline $\begin{array}{l}\text { Schückes \& Gutmann (2020) } \\
\text { Why do startups pursue ICOs? } \\
\text { The role of economic drivers and } \\
\text { social identity on funding choice }\end{array}$ & $\begin{array}{l}\text { Empirical } \\
\text { research study } \\
\text { / Qualitative }\end{array}$ & $\begin{array}{l}\text { The entrepreneur's social identity in conjunction with } \\
\text { the enabling mechanisms of BT shape entrepreneurial } \\
\text { pursuits and funding choice. }\end{array}$ \\
\hline \multicolumn{3}{|c|}{ BT as an external enabler/Digital entrepreneurship } \\
\hline $\begin{array}{l}\text { Chalmers, Matthews, \& Hyslop } \\
\text { (2019) } \\
\text { Blockchain as an external } \\
\text { enabler of new venture ideas: } \\
\text { Digital entrepreneurs \& the } \\
\text { disintermediation of the global } \\
\text { music industry }\end{array}$ & $\begin{array}{c}\text { Literature } \\
\text { review, } 11 \text { case } \\
\text { studies / } \\
\text { A model of } \\
\text { new venture } \\
\text { idea \& } \\
\text { external } \\
\text { enabler } \\
\text { shaping }\end{array}$ & $\begin{array}{l}3 \text { external enablers of new venture ideas in the context } \\
\text { of music industry: ideology, market volatility, and the } \\
\text { focal technological enabler BT. Entrepreneurial actors } \\
\text { engaged in a set of venture-level work practices that } \\
\text { allowed them to: discover and learn about enablers; scan } \\
\text { the industry context to establish a differentiated value } \\
\text { proposition; synthesise and ideate a range of new venture } \\
\text { ideas. }\end{array}$ \\
\hline $\begin{array}{l}\text { Mickiewicz \& Rebmann (2020) } \\
\text { Entrepreneurship as Trust }\end{array}$ & $\begin{array}{l}\text { Conceptual } \\
\text { paper }\end{array}$ & $\begin{array}{l}\mathrm{BT} \text { is enabling entrepreneurs to create a new form of } \\
\text { distributed trust between strangers. }\end{array}$ \\
\hline
\end{tabular}


BT \& Institutional and entrepreneurial theory / institutional economics/cryptoeconomics

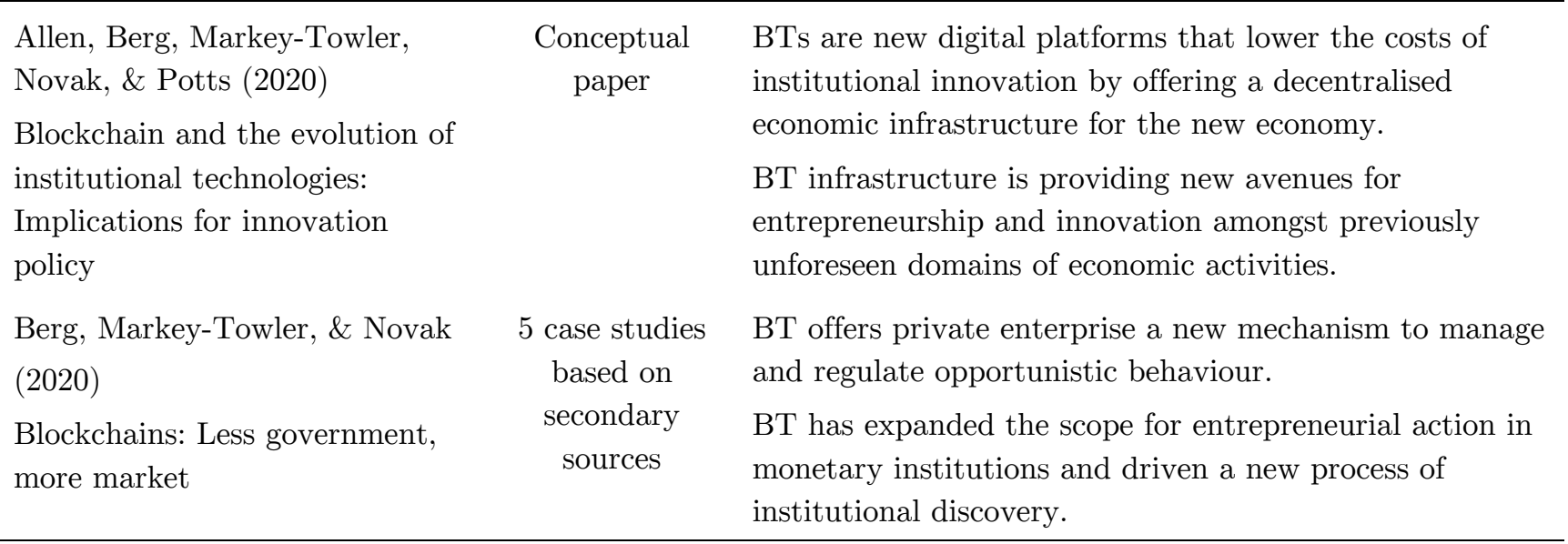

BT \& Social entrepreneurship

\begin{tabular}{lcl}
$\begin{array}{l}\text { Devereaux (2020) } \\
\text { The digital Wild West: on social } \\
\text { entrepreneurship in } \\
\text { extended reality }\end{array}$ & $\begin{array}{c}\text { Conceptual } \\
\text { paper }\end{array}$ & $\begin{array}{l}\text { Social entrepreneurship in BT solutions may very well be } \\
\text { able to meet some of the challenges presented by rapidly } \\
\text { advancing extended reality (XR). }\end{array}$ \\
$\begin{array}{l}\text { Gogan \& Goode } \\
\text { (2020) }\end{array}$ & $\begin{array}{c}\text { A single-case } \\
\text { study }\end{array}$ & $\begin{array}{l}\text { Multiple forms of IT agility, multiple forms of business } \\
\text { agility, and a unique form of social-commercial agility } \\
\text { help an IT-enabled hybrid social startup persist, despite } \\
\text { startup }\end{array}$ \\
& $\begin{array}{l}\text { financial and other challenges. BT is an early stage IS } \\
\text { innovation in health care. }\end{array}$ \\
\hline
\end{tabular}

BT \& Business models

$\begin{array}{lcl}\begin{array}{l}\text { Morkunas, Paschen, \& Boon } \\ (2019)\end{array} & \begin{array}{c}\text { Case studies } \\ \text { based on } \\ \text { secondary } \\ \text { sources } \\ \begin{array}{l}\text { How blockchain technologies } \\ \text { impact your business model }\end{array}\end{array} & \begin{array}{l}\text { Presenting the influence BT technologies can have on a } \\ \text { firm's business model based on the examples of BT } \\ \text { development startups across different industries and } \\ \text { countries. }\end{array} \\ \begin{array}{l}\text { Weking, Mandalenakis, Hein, } \\ \text { Hermes, Böhm, \& Krcmar }\end{array} & \begin{array}{c}\text { Design science } \\ \text { research }\end{array} & \begin{array}{l}\text { Based on 99 BT ventures, 5 archetypal patterns of } \\ \text { business models leveraging BT are defined: }\end{array} \\ \begin{array}{l}\text { (2019) } \\ \text { The impact of blockchain } \\ \text { technology on business models }-\end{array} & \begin{array}{l}\text { BT for Security, BT Technology as Offering, and BT for } \\ \text { a taxonomy and archetypal } \\ \text { patterns }\end{array} & \text { Monetary Value Transfer. }\end{array}$


BT \& Internationalisation of firm

Zalan (2018)

Born global on blockchain
General review

/Viewpoint
Most of start-ups are genuinely "born global" as there are no technical restrictions on BT deployment because it is open sourced, decentralised, and globally distributed by its nature, and a start-up's developer teams, funders, users and exchanges listing their tokens can be located anywhere around the globe.

Source: own compilation. Note: Due to the space limitation, a few papers are presented in the table. The full version is available from the author upon request.

\section{Discussion and recommendations}

Based on the literature review of the research works, the key characteristics of the BT industry are primarily summarised. According to Park et al. (2020), the ecosystem of BT innovation differs from other existing high technology industries in terms of competition among players. Firstly, the sharing and disclosure of technological details are active in the BT industry through the development of platforms (e.g., Bitcoin, Ethereum) and white papers published by start-ups to disseminate their vision for a new offering (Fisch, 2019). In contrast, firms in other technology industries tend to conceal their technologies. Secondly, the development and imitation of BT are easier compared with other high technologies due to its features and underlying algorithms. The BT industry is characterised by active knowledge transfers among startups (e.g., conference activities, Demo Days). In general, BT innovation is widely exploited by highly innovative startups; this is in line with previous research works (Audretsch, 2002; Giarratana, 2004; Shane, 2001). Most of those start-ups are at the early R\&D stage and "born global" companies (Zalan, 2018). Further, the determining factors on the success of BT-based companies are outlined by applying Giarratana's (2004) guidelines:

Environment. The conditions of the external environment affect the adoption of BT and the entry and success of the BT-enabled firms. Countries that exhibit a more welcoming policy stance are more likely to attract entrepreneurs and investors in the cryptoeconomic blockchain space (Novak, 2019). Allen (2019) also suggests that the BT policy within early-stage entrepreneurship should focus on how existing policies inhibit the process of an emergent entrepreneurial organisation. One of the factors to the success or failure of the venture are business strategies and due diligence to comply with all relevant regulations (Dos Santos \& Chaczko, 2019). Therefore, the barriers to full use of BT can be mitigated via the formation of strategic associations and entrepreneurs' dissemination work that influence regulations and standards (Chalmers et al., 2019). 
Both startup and incumbent companies may rely on collaborative networks (García Sáez, 2020).

Entrepreneurs. In the early stages of firm creation, an entrepreneur acts on behalf of the entire organisation by interacting with broader community and industry context (Gogan et al., 2020). Entrepreneurs' active engagement in sharing their expertise in core business activities positively influences the status of the firm. Their dissemination and field-level shaping activities on new technology can impact the competitors' new venture ideation processes and establish credibility within the competitive space. Chalmers et al. (2019) stated that such work was instrumental in demystifying BT to established firms and accelerating the potential collaboration options. In order to attract talent, García Sáez (2020) recommended start-ups to communicate openly about their objectives, values, and culture.

New product/process. According to Fiedler and Sandner (2017), the BT startup ecosystem is dominated by start-ups with a profound business model and experienced management that was able to solve infrastructural problems or inefficiencies. The technology can both provide disruption in well-established business models and offer solutions to industries with structural issues (Nowiński \& Kozma, 2017). Due to the rapidly evolving nature of BT, Chalmers et al. (2019) stated the necessity for ventures to constantly update their knowledge of technological developments and their alignment with venture ideas.

Thus, the present research work contributed to the literature on BT-related research by presenting classification on the existing literature sources dedicated to BT and entrepreneurship. The research stream on BT and novel forms of entrepreneurial finance (i.e., ICOs) is predominant, followed by the research on BT in the contexts of institutional and entrepreneurial theory, digital and social entrepreneurship, business models, and international business. A summary of the characteristics of the BT industry and new BTbased ventures was presented.

Policymakers are recommended to support the creation of new ventures and provide incentives for entrepreneurs and other business-oriented people to set up new high-tech firms. As regards incumbent companies, managers should cooperate with start-ups to adopt BT applications into their business models and profit from this technology. Future research should be based on empirical research studies (both qualitative and quantitative), namely cluster analysis, to identify the determinants of success and failure of BT-enabled firms 


\section{References}

Ahluwalia, S., Mahto, R. V., \& Guerrero, M. (2020). Blockchain technology and startup financing: A transaction cost economics perspective. Technological Forecasting and Social Change, 151, 119854. https://doi.org/10.1016/j.techfore.2019.119854

Allen, D. W. E. (2019). Governing the entrepreneurial discovery of blockchain applications. Journal of Entrepreneurship and Public Policy, 9(2), 194-212. https://doi.org/10.1108/JEPP-03-2019-0017

Allen, D. W. E., Berg, C., Markey-Towler, B., Novak, M., \& Potts, J. (2020). Blockchain and the evolution of institutional technologies: Implications for innovation policy. Research Policy, 49(1), 103865. https://doi.org/10.1016/j.respol.2019.103865

Audretsch, D. B. (2002). The dynamic role of small firms: Evidence from the U.S. Small Business Economics, 18(1-3), 13-40. https://doi.org/10.1023/A:1015105222884

Berg, A., Markey-Towler, B., \& Novak, M. (2020). Blockchains: Less government, more market. Journal of Private Enterprise, 35(2), 1-21. https://doi.org/10.2139/ssrn.3301714

Casper, S., \& Whitley, R. (2004). Managing competences in entrepreneurial technology firms: A comparative institutional analysis of Germany, Sweden and the UK. Research Policy, 33(1), 89-106. https://doi.org/10.1016/S0048-7333(03)00100-8

Chalmers, D., Matthews, R., \& Hyslop, A. (2019). Blockchain as an external enabler of new venture ideas: Digital entrepreneurs and the disintermediation of the global music industry. Journal of Business Research, 1-15. https://doi.org/10.1016/j.jbusres.2019.09.002

Chen, K. (2019). Information asymmetry in initial coin offerings (ICOs): Investigating the effects of multiple channel signals. Electronic Commerce Research and Applications, 36, 100858. https://doi.org/10.1016/j.elerap.2019.100858

Chen, Y. (2018). Blockchain tokens and the potential democratisation of entrepreneurship and innovation. Business Horizons, 61(4), 567-575. https://doi.org/10.1016/j.bushor.2018.03.006

Colombelli, A., Krafft, J., \& Quatraro, F. (2014). The emergence of new technology-based sectors in European regions: A proximity-based analysis of nanotechnology. Research Policy, 43(10), 1681-1696. https://doi.org/10.1016/j.respol.2014.07.008

Devereaux, A. (2020). The digital Wild West: on social entrepreneurship in extended reality. Journal of Entrepreneurship and Public Policy. https://doi.org/10.1108/jepp-03-20190018

Dos Santos, A. P., \& Chaczko, Z. (2019). Blockchain: Status-quo, enablers and inhibitors. 26th International Conference on Systems Engineering, ICSEng 2018 - Proceedings, December 2018. https://doi.org/10.1109/ICSENG.2018.8638187

Fiedler, M., \& Sandner, P. (2017). Identifying leading blockchain startups on a worldwide level. In Frankfurt School Blockchain Center (FSBC) Working Paper. http://www.exploreip.com/2017_Analysis-of-leading-blockchain-startups-worldwide.pdf

Fisch, C. (2019). Initial coin offerings (ICOs) to finance new ventures. Journal of Business Venturing, 34(1), 1-22. https://doi.org/10.1016/j.jbusvent.2018.09.007 
García Sáez, M. I. (2020). Blockchain-enabled platforms: Challenges and recommendations. International Journal of Interactive Multimedia and Artificial Intelligence, 6(3), 73. https://doi.org/10.9781/ijimai.2020.08.005

Gartner, W. B. (1985). A conceptual framework for describing the phenomenon of new venture creation. Academy of Management Review, 10(4), 696-706. https://doi.org/https://doi.org/10.5465/amr.1985.4279094

Giarratana, M. S. (2004). The birth of a new industry: Entry by start-ups and the drivers of firm growth: The case of encryption software. Research Policy, 33(5), 787-806. https://doi.org/10.1016/j.respol.2004.01.001

Gogan, J. L., Goode, H. E., Gogan, J., \& Goode, H. E. (2020). An agile IT-enabled social startup. Conference of the Association-for-Information-Systems (AMCIS) 2020 Proceedings. 4. https://aisel.aisnet.org/amcis2020/social_inclusion/social_inclusion/4

Hart, C. (1998). Doing a literature review: Releasing the social science research imagination. Thousand Oaks: Sage.

Harzing, A. W., \& Alakangas, S. (2016). Google Scholar, Scopus and the Web of Science: a longitudinal and cross-disciplinary comparison. Scientometrics, 106(2), 787-804. https://doi.org/10.1007/s11192-015-1798-9

Jackson, E. (2017). Blockchain will turn the internet into the world's largest 'stock' market, says investor. CNBC. https://www.cnbc.com/2017/09/05/balaji-srinivasan-21-co-interviewon-blockchain.html

Jain, S., \& Simha, R. (2018). Blockchain for the common good: A digital currency for citizen philanthropy and social entrepreneurship. Proceedings - IEEE 2018 International Congress on Cybermatics: 2018 IEEE Conferences on Internet of Things, Green Computing and Communications, Cyber, Physical and Social Computing, Smart Data, Blockchain, Computer and Information Technology, IThings/Gree, 1387-1394. https://doi.org/10.1109/Cybermatics_2018.2018.00238

Jáki, E., Molnár, E. M., \& Kádár, B. (2019). Characteristics and challenges of the Hungarian startup ecosystem. Vezetéstudomány / Budapest Management Review, 50(5), 2-12. https://doi.org/10.14267/veztud.2019.05.01

Kher, R., Terjesen, S., \& Liu, C. (2020). Blockchain, Bitcoin, and ICOs: a review and research agenda. Small Business Economics. https://doi.org/10.1007/s11187-019-00286-y

Krafft, J., Lechevalier, S., Quatraro, F., \& Storz, C. (2014). Emergence and evolution of new industries: The path-dependent dynamics of knowledge creation. An introduction to the special section. Research Policy, 43(10), 1663-1665.

https://doi.org/10.1016/j.respol.2014.07.006

Li, K., Rollins, J., \& Yan, E. (2018). Web of Science use in published research and review papers 1997-2017: a selective, dynamic, cross-domain, content-based analysis.

Scientometrics, 115(1), 1-20. https://doi.org/10.1007/s11192-017-2622-5

Liu, S. (2020). Blockchain technology market size worldwide 2018-2025. Statista. https://www.statista.com/statistics /647231/worldwide-blockchain-technology-marketsize/ 
Massey, R., Dalan, D., \& Dakshinamoorthy, A. (2017). Initial coin offering: A new paradigm. Deloitte, 10. https://www2.deloitte.com/content/dam/Deloitte/us/Documents/processand-operations/us-cons-new-paradigm.pdf

Mickiewicz, T., \& Rebmann, A. (2020). Entrepreneurship as trust. Foundations and Trends@ in Entrepreneurship, 16(3), 244-309. https://doi.org/10.1561/0300000088

Morkunas, V. J., Paschen, J., \& Boon, E. (2019). How blockchain technologies impact your business model. Business Horizons, 62(3), 295-306. https://doi.org/10.1016/j.bushor.2019.01.009

Nambisan, S. (2017). Digital entrepreneurship: Toward a digital technology perspective of entrepreneurship. Entrepreneurship: Theory and Practice, 41(6), 1029-1055. https://doi.org/10.1111/etap.12254

Novak, M. (2019). Crypto-friendliness: understanding blockchain public policy. Journal of Entrepreneurship and Public Policy, 9(2), 165-184. https://doi.org/10.1108/JEPP-032019-0014

Nowiński, W., \& Kozma, M. (2017). How can blockchain technology disrupt the existing business models? Entrepreneurial Business and Economics Review, 5(3), 173-188. https://doi.org/10.15678/EBER.2017.050309

Park, G., Shin, S. R., \& Choy, M. (2020). Early mover (dis)advantages and knowledge spillover effects on blockchain startups' funding and innovation performance. Journal of Business Research, 109(C), 64-75. https://doi.org/10.1016/j.jbusres.2019.11.068

Park, J. Y., \& Sung, C. S. (2020). A business model analysis of blockchain technology-based startup. Entrepreneurship and Sustainability Issues, 7(4), 3048-3060. https://doi.org/10.9770/jesi.2020.7.4(32)

Schückes, M., \& Gutmann, T. (2020). Why do startups pursue initial coin offerings (ICOs)? The role of economic drivers and social identity on funding choice. Small Business Economics. https://doi.org/10.1007/s11187-020-00337-9

Shane, S. (2001). Technology regimes and new firm formation. Management Science, $47(9)$, 1173-1190. https://doi.org/10.1287/mnsc.47.9.1173.9785

Unalan, S., \& Ozcan, S. (2020). Democratising systems of innovations based on blockchain platform technologies. Journal of Enterprise Information Management, 33(6), 1511-1536. https://doi.org/10.1108/jeim-07-2018-0147

Weking, J., Mandalenakis, M., Hein, A., Hermes, S., Böhm, M., \& Krcmar, H. (2019). The impact of blockchain technology on business models - a taxonomy and archetypal patterns. Electronic Markets. https://doi.org/10.1007/s12525-019-00386-3

Zalan, T. (2018). Born global on blockchain. Review of International Business and Strategy, 28(1), 19-34. https://doi.org/10.1108/RIBS-08-2017-0069 


\title{
Nascent Entrepreneurship: Exploratory Research Based on Systematic Literature Review and Text Analysis
}

\author{
KRISZTOFER SZABÓ* \\ *Corvinus University of Budapest, Doctoral School of Business and Management; \\ krisztofer.szabo@uni-corvinus.hu
}

DOI: $10.14267 / 978-963-503-867-1 \_14$

\begin{abstract}
A brilliant idea means nothing if it stays in someone's mind and doesn't come to life. The process of an idea developed into a new business is very unstable, like a balloon in the wind that can blow in any possible direction. Sometimes the idea gets thrown away, sometimes it creates something extraordinary. Studies on nascent entrepreneurs contribute to the understanding of the factors affecting the intention of an individual to become an entrepreneur. Nascent entrepreneurship is a rather new topic of research. There are large number of journals on the topic only since the early 2000's. There are several challenges in defining the topic accurately since the beginning and the end of the process is not always clear. Sometimes it is difficult to distinguish between the idea phase and the ongoing work in progress. In addition, research results are difficult to compare with each other because of conceptual uncertainties and different approaches. In this paper the most important literary background related to nascent entrepreneurship is presented. In this study, keyword searches reveal the most frequently researched conceptual approaches to the intention of starting a new business. In the critical analysis of selected papers, the research is confined to the field of business and management and economics, which I explore with the steps of the Systematic Literature Review methodology. In the comprehensive literature review is based on bibliometric analysis and quantitative text analysis. Results, proposals and future research areas are also presented.
\end{abstract}

Keywords: nascent entrepreneurship, systematic literature review, bibliometric analysis, text analysis

Funding: The author did not receive any grant or institutional support in relation to the study's preparation. 


\section{Introduction}

The importance of studying entrepreneurship should be undisputable, since that, entrepreneurship is the process brought about by individuals of identifying new opportunities and converting them into marketable products or services (Schaper \& Volery, 2004). It has great relevance to investigate and analyse the beginning parts of being an entrepreneurship to get better understanding. Entrepreneurship studies at individual level revealed a number of theoretical and empirical approaches to explaining new companies' births, often from a process approach (Gelderen, et al. 2006; Dimov, 2007; Teece, 2007; Harper, 2008). Furthermore, number of conceptual definitions have been written in the recent years, and the term of nascent entrepreneurship was created. With the method of systematic literature review a better understanding could be established from the last 20 years about the topic. In the field of entrepreneurship literature, a new venture is defined as an enterprise is not older than six to eight years. One recognized researcher on the entrepreneurial creation studies, Biggadike (1979) set the limit at an eight-year time period for new ventures to reach the level of existing companies. Nonetheless, the most studies in the last years, seems to agree on six years of age or less (Brush, 1995; Kunkel, 1991; Robinson, 1999; Jáki et. al 2019; Shrader et al., 2000).

The definition of a nascent entrepreneur is difficult to determine because it is often unclear where the process begins and will be ends. Hopp \& Sonderegger (2015) define it as teams and individuals who (1) want to start a new business, (2) have already done some entrepreneurial activities to help start business, (3) who expect to own at least part of the new business and (4) who do not have any existing business. Therefore, the difference between a nascent entrepreneur and an actual entrepreneur is that the latter is a person who has already started and operates the business (van Stel et al., 2007). However, the term 'nascent entrepreneur' does not exclude entrepreneurs who already have experience from previous enterprises. Accordingly, the 'nascent' reflects the current and ongoing efforts to create a new business (Hopp \& Sonderegger, 2015). Researchers have chosen very diverse research approaches in the nascent entrepreneurship over the last two decades. It is important to review existing studies in order to prepare a new research. Therefore, I aim to prepare an exploratory study with systematic literature review about nascent entrepreneurship to identify the most popular journals and make quantitative research to find the most relevant keywords. This will narrow down the boundaries and find new guidelines for future research. 


\section{Methods}

In order to identify the articles, I focused to 'Scopus' scientific online database. By using this electronic archive, I was able to create a focused and comprehensive literature review. For searching and filtering purposes, the following keyword was used: 'nascent entrepr*' (where * stands for an indefinite number of free characters). I intentionally used one search keyword to focus the most on the topic. To determine the final results, I performed a four steps search. Firstly, in the 'base search' I defined the following restrictions:

- considered to articles and reviews only;

- published between 2000 and 2020;

- searched in titles, keywords and abstracts;

- delamination to only Business, Management and Accounting subject area.

These conditions gave me the possibility to focus on the current state of exploratory research both on time and on the subject. This literature search method resulted in a list of 666 articles. There were too many articles in this search, thus I narrowed down the list by looking only for the title and/or keywords to give a greater chance of finding relevant results. On the next step, the keywords and abstracts searches were eliminated, focusing only on nascent entrepreneurship appearing the titles. All other filter conditions remained unchanged. This search resulted in 147 articles. Thirdly, one restriction has changed, the search filtered only for keywords (leaving the titles and abstracts) which resulted in 189 papers. I identified that, there are matching hits between the results of the last two filtered searches. Consequently, the results were aggregated (final filtered criterion was search in titles OR keywords, all other restrictions as described above). The final list has included 257 different articles. 
Figure 1: The research model of Systematic Literature Review

\begin{tabular}{|c|c|c|c|}
\hline Steps & Search & Restrictions & Hits \\
\hline Base search & $\begin{array}{l}\text { - Scopus } \\
\text { - Keyword: "nascent entrepr*" }\end{array}$ & $\begin{array}{l}\text { - Search in: Title, Keywords, Abstract } \\
\text { - Journal articles and reviews only } \\
\text { - Year: } 2000-2020 \\
\text { Subject area: Business, } \\
\text { Management and Accounting }\end{array}$ & 666 different articles \\
\hline Filtered search I. & $\begin{array}{l}\text { - Scopus } \\
\text { - Keyword: "nascent entrepr*" }\end{array}$ & $\begin{array}{l}\text { - Search in: Only Title } \\
\text { - Journal articles and reviews only } \\
\text { - Year: } 2000-2020 \\
\text { Subject area: Business, } \\
\text { Management and Accounting }\end{array}$ & 147 articles \\
\hline Filtered search II. & $\begin{array}{l}\text { - Scopus } \\
\text { - Keyword: "nascent entrepr*" }\end{array}$ & $\begin{array}{l}\text { - Search in: Only Keywords } \\
\text { - Journal articles and reviews only } \\
\text { - Year: } 2000-2020 \\
\text { Subject area: Business, } \\
\text { Management and Accounting }\end{array}$ & 189 articles \\
\hline Final search & $\begin{array}{ll}\text { - Scopus } \\
\text { - Keyword: "nascent entrepr*" }\end{array}$ & $\begin{array}{l}\text { - Search in: Only Title OR Keywords } \\
\text { - Journal articles and reviews only } \\
\text { - } \quad \text { Subject area: Business, } \\
\text { Management and Accounting }\end{array}$ & 257 differe \\
\hline
\end{tabular}

Source: own illustration

\section{Results}

In the subsequent parts, I conducted bibliometric analysis and quantitative text analysis, which results come to introduce.

\section{Bibliometric analysis}

Analysing the time series of the selected articles (between 2000 and 2020), it seems that the largest number of journal publications in this field were published in the last year (see Figure 2). It is good proof of the topic being increasingly in the focus of scientific attention. 
Figure 2: Trends of published articles between 2000-2020

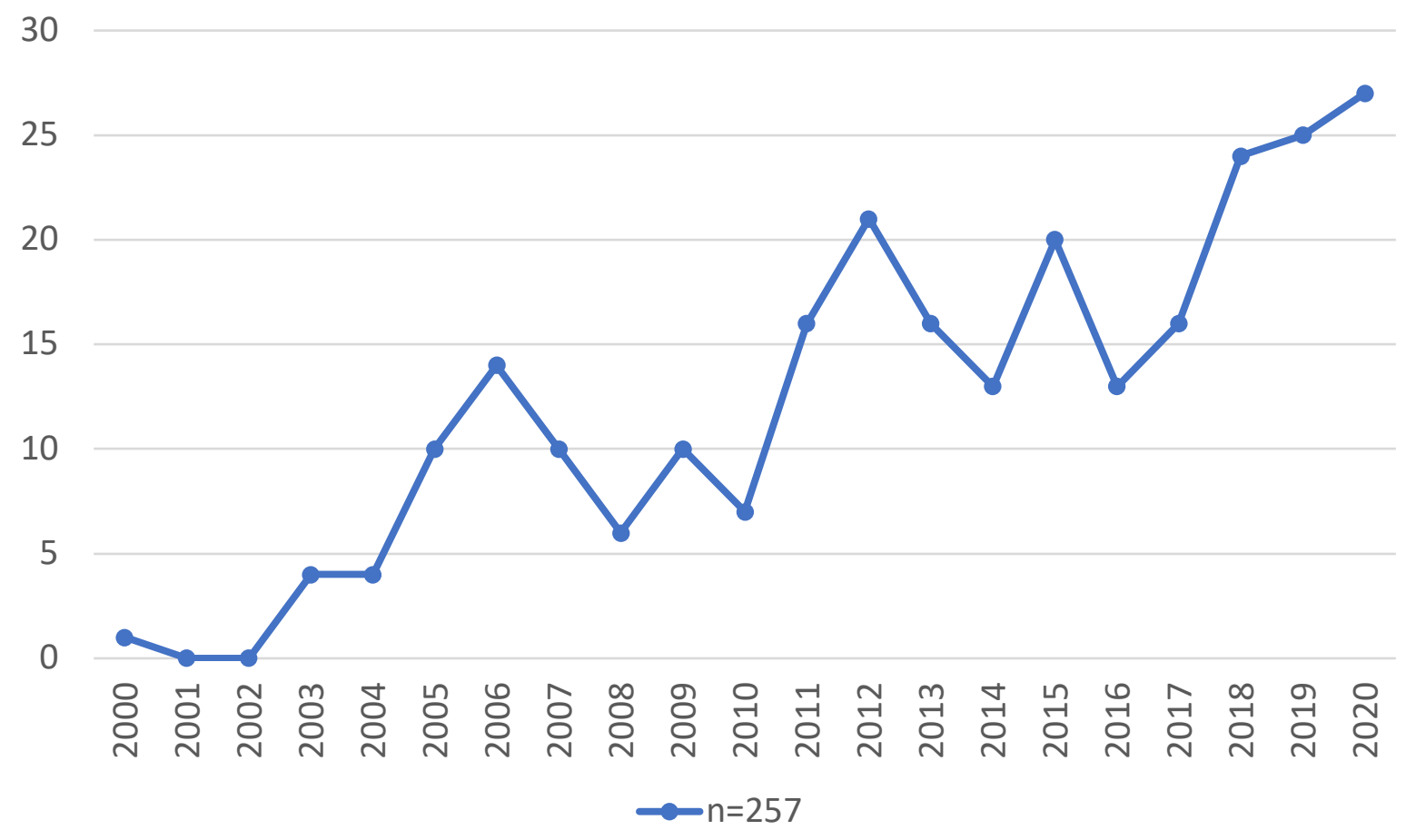

Source: own illustration by Scopus database

Regarding the journals' analysis and rankings analysis, these articles were filtered based on the quality by Scimago Journals Ranking (SJR). Q1, Q2, Q3 and Q4 categories are distinguished where Q1 is the highest quality. In Figure 3, it seems the most articles published in high ranked journals (64\% of the articles have Q1, 23\% papers have Q2 ranked, and no more than $13 \%$ have in lower category journals). These data show that, the elite of academic public are interested in this scientific field especially. Accordingly, high-quality research is made continuously in the topic, which is a great option to read and collect professional literature. I can build my future research through them and publishing in Q1 or Q2 ranked journals probably later. 
Figure 3: Number of articles by Scimago Journal Ranking

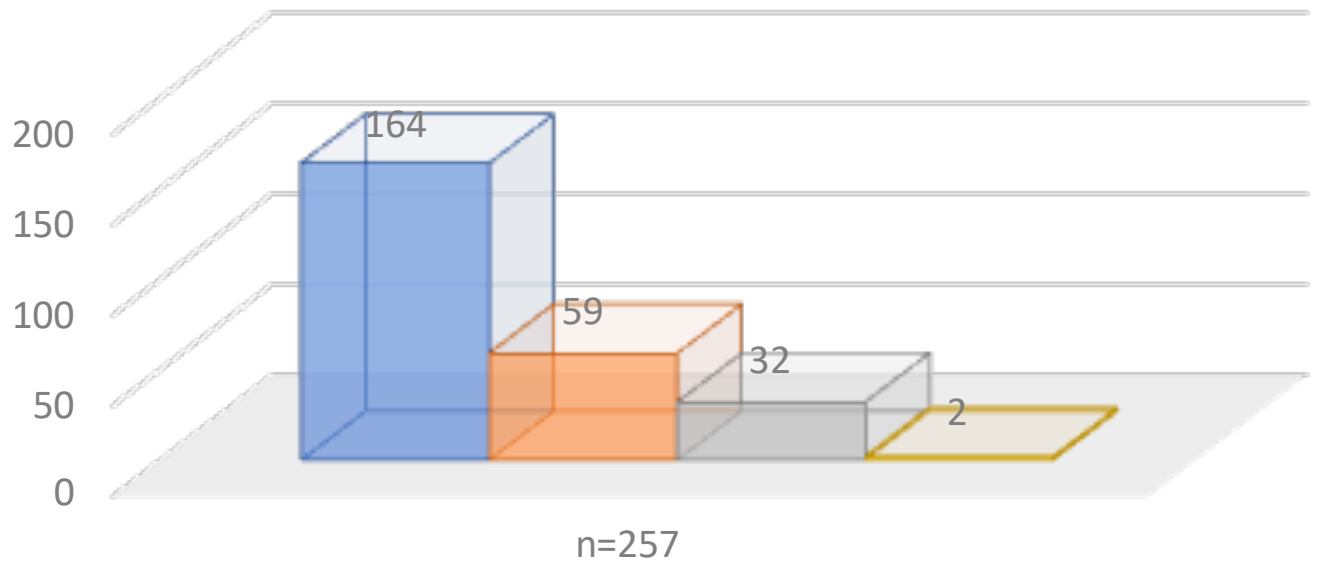

Q1 $\square$ Q2 $\square$ Q3 $\square$ Q4

Source: own illustration by Scopus database

At the end of the bibliometric research, a list of TOP 10 journals was created based on the number of articles (see Table 1). In this list, there are only two lower quality journals that prove the high-quality attention to this research theme once again. Small Business Economics Journal has the largest number of papers in this list, which is a highly ranked journal in the field of business and management sciences. The topic is well defined (not interdisciplinary), and primarily publishing in the entrepreneurial journals. In addition, this list also shows that, which journals are the most relevant for future research. 
Table 1: Summary of the top 10 journals contains the SJR

\begin{tabular}{llll}
\hline Nr. & Source Title & $\begin{array}{l}\text { SJR } \\
\text { ranking }\end{array}$ & Number of hits \\
\hline 1. & Small Business Economics & Q1 & 41 \\
2. & Entrepreneurship and Regional Development & Q1 & 13 \\
3. & Journal of Developmental Entrepreneurship & Q3 & 12 \\
4. & International Journal of Entrepreneurial Behaviour and & Q1 & 11 \\
& Research & Q1 & 11 \\
5. & Journal of Business Venturing & Q1 & 11 \\
6. & Journal of Business Venturing Insights & Q1 & 11 \\
7. & Journal of Small Business Management & Q1 & 10 \\
8. & International Entrepreneurship and Management Journal & 9 \\
9. & International Journal of Entrepreneurship and Small & Q2 & \\
& Business & & 7 \\
10. & Entrepreneurship: Theory and Practice & Q1 & \\
\hline
\end{tabular}

Source: own illustration by Scopus database

\section{Text analysis}

The second part of the quantitative analysis is to examine the selected articles' titles and keywords with text analysis methods. I used the 'WORDij' software for the frequently analysis of used words. These words have illustrated by word cloud below. Figure 4 shows the most frequently 30 words in paper titles, and Figure 5 illustrates the results in paper keywords. (Where the font size is larger, it was more frequently applied as a keyword. The green and orange colours show the matching words between the two analysis.) Beginning of the analysis started, I removed the words that did not contain relevant information (conjunctions definite and indefinite articles and other language elements) by subjective professional filtering content. With this method, only the words with thematic meaning remained in the analysis. 
Figure 4: Most frequently 30 words in paper titles

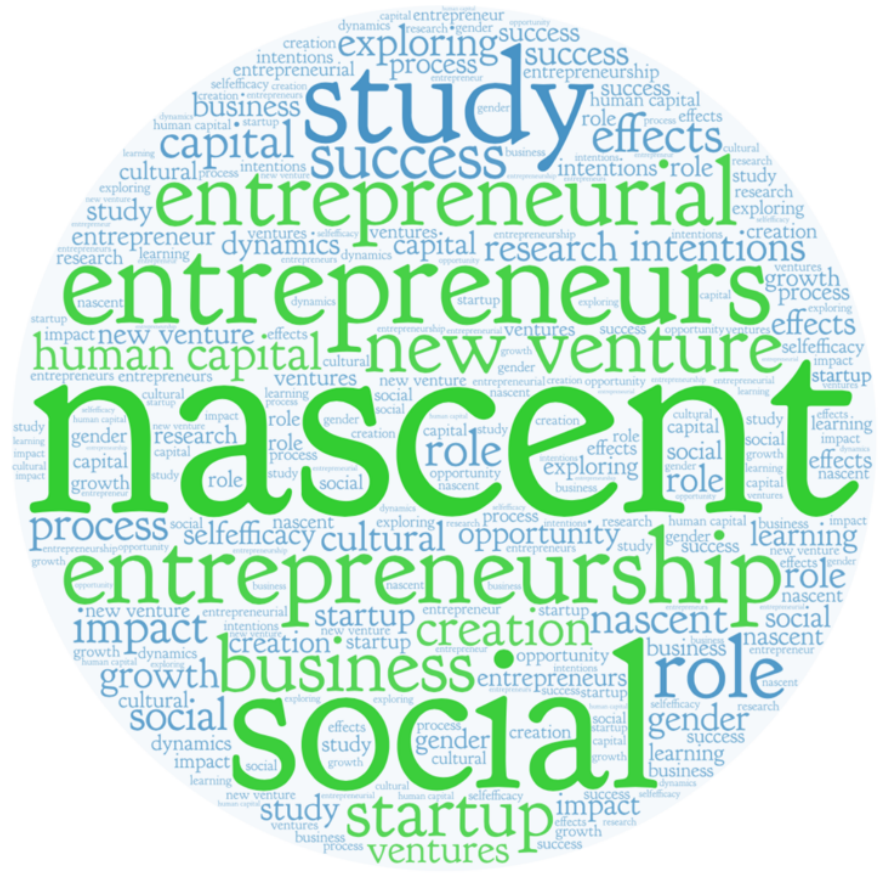

Source: own illustration by WORDij and WordArt sofwares

Figure 5: Most frequently 30 words in paper keywords

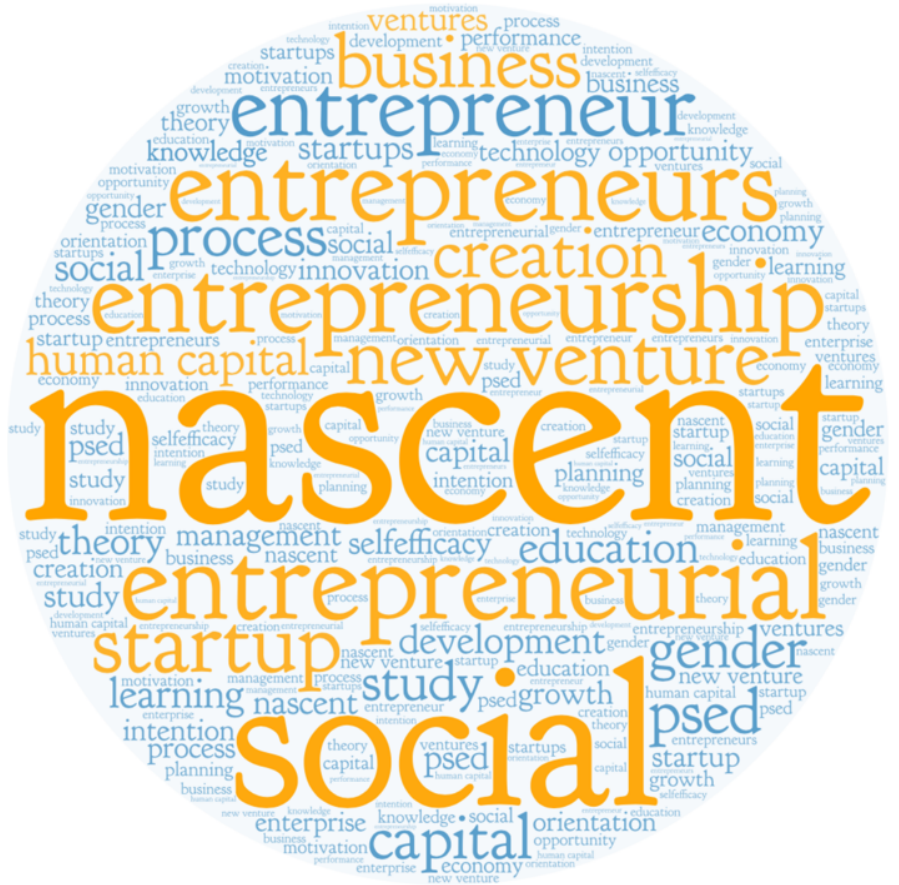

Source: Own illustration by WORDij and WordArt sofwares 
Through the search performed I found new relevant keywords that could help my future research about the nascent entrepreneurship. In the list below, I have collected the 10 most common hits (both in titles and keywords):
a) nascent
b) entrepreneurship
c) entrepreneurial
d) entrepreneurs
e) social
f) startup
g) business
h) venture
i) creation
j) human

Based search keywords can identify (as nascent, entrepreneurship and the synonyms of it), however other connecting words can see in the word clouds and also in the short list. Terms and their synonyms are included in the list above (and in the whole list of results), such as social, capital, human, startup, process, management, performance etc.

This exploratory study also shows the following topics can be segmented during the keywords: geographic, focus, perspective, factor, goal, research.

In a previous study (Aranyossy \& Szabó, 2020) different themes (variables) were identified such as human capital, business planning, social capital, environment, entrepreneurial intention. The results indicate a close similarity to each other.

Using the words above, new literature research can be done by combining the keywords to have a more in depth-knowledge about the topic and segment them to different keyword categories. 


\section{Conclusion and directions for future research}

In this study I have sought to better understand the current state of research focusing on 'nascent entrepreneurship'. In order to take the first step for the exploratory research, I conducted a systematic literature review and then bibliometric- and quantitative analysis of content based on bibliographic data, titles and keywords in academic articles.

The results show that, the topic attracted increasing scientific interest in the last decades, more and more studies are being carried out on nascent entrepreneurship. The most articles had been published in high quality ranked journals (in particular entrepreneurship journals), which show the professionality and limitations of the topic. Working from such articles, it is a great possibility for future research and write publication in high-ranking journals.

In my opinion, it is a great research topic to explore new possibilities in this field, as more and more studies are being prepared. Based on the results, I became sure of the topic's relevance, which can be continued by identify different keyword categories in subsequent research. It is important to note that, this study is also related to previous results, which proves the direction of the research.

Additional option to perform a text analysis also in the abstracts and make word pair analysis. Accordingly, the topic will be thoroughly limited, I am able to find the most relevant articles and do specific research in the future (for example, a qualitative content analysis from the selected articles).

\section{References}

Aranyossy, M. \& Szabó, K. (2020). What affects entrepreneurial intention? A systematic literature review on nascent entrepreneurship and motivational background. In: N. Deutsch, (Eds.) Diversity of Business Development Vol. V.: Thought-provoking ideas and notes

(pp. 25-38). Saarbrücken, Germany: Lambert Academic Publishing

Biggadike, E.R. (1979). Corporate diversification: Entry, strategy, and performance. Cambridge:

Division of Research, Graduate School of Business Administration, Harvard University.

Brush, C.G. (1995). International entrepreneurship: The effects of firm age on motives of internationalization. New York: Garland Publishing Co.

Dimov, D. (2007). From opportunity insight to opportunity intention: The importance of person-situation learning match. Entrepreneurship Theory and Practice, 31(4), 561-583. https://doi.org/10.1111/j.1540-6520.2007.00188.x 
Gelderen, M.V., Thurik, R., \& Bosma, N. (2006). Success and risk factors in the pre-startup phase. Small Business Economics, 26(4), 319-335. https://doi.org/10.1007/s11187-004$6837-5$

Harper, D.A. (2008). Towards a theory of entrepreneurial teams. Journal of Business Venturing, 23(6), 613-626. https://doi.org/10.1016/j.jbusvent.2008.01.002

Hopp, C. \& Sonderegger, R. (2015). Understanding the Dynamics of Nascent EntrepreneurshipPrestart-Up Experience, Intentions, and Entrepreneurial Success. Journals Small Business Management, 53(4), 1076-1096. https://doi.org/10.1111/jsbm.12107

Jáki, E., Molnár, E.M. \& Kádár, B. (2019). Characteristics and challenges of the Hungarian startup ecosystem. Vezetéstudomány/Budapest Management Review, 50(5), 2-12. https://doi.org/10.14267/VEZTUD.2019.05.01

Kunkel, S.W. (1991). The impact of strategy and industry structure on new venture performance. University of Georgia: Unpublished Doctoral Dissertation

Robinson, K.C. (1999). An examination of the influence of industry structure on eight alternative measures of new venture performance for high potential independent new ventures. Journal of Business Venturing, 14(2), 165-187.

https://doi.org/10.1016/S0883-9026(97)00083-9

Scopus website 2020. 'Number of published articles with the keyword »nascent entrepr* «" www.scopus.com

Schaper, M. \& Volery, T. (2004). Entrepreneurship and Small Business: A Pacific Rim Perspective. Milton, Qld.: John Wiley \& Sons Australia.

Shrader, R.C., Oviatt, B.M. \& McDougall, P.P. (2000). How New Ventures Exploit Trade-Offs among International Risk Factors: Lessons for the Accelerated Internationalization of the 21st Century. Academy Management Journal, 43(6), 1227-1247. https://doi.org/10.2307/1556347

Teece, D.J. (2007). Explicating dynamic capabilities: The nature and microfoundations of (sustainable) enterprise performance. Strategic Management Journal, 28(13), 1319-1350. https://doi.org/10.1002/smj.640

van Stel, A., Storey, D.J. \& Thurik, A.R. (2007). The Effect of Business Regulations on Nascent and Young Business Entrepreneurship. Small Business Economics, 28(2-3), 171-186. https://doi.org/10.1007/s11187-006-9014-1 


\title{
Business Model Innovation and the First Steps of Digitalization in the Case of Symphony Orchestras
}

\author{
BORBÁLA SZEDMÁK* \\ *Corvinus University of Budapest, Institute for the Development of Enterprises; \\ borbala.szedmak@uni-corvinus.hu
}

DOI: $10.14267 / 978-963-503-867-1 \_15$

\begin{abstract}
The study highlights the importance of orchestras being able to respond to the changing needs of consumers and adapt to changes in the world. Such a change is, for example, the current coronavirus epidemic, which poses especially great difficulties for organizations of the cultural sector that deal with performing arts, as concerts and performances - providing the basis of their operation - have become impossible. In order to gain "immunity" to the virus, business model innovation and exploiting opportunities offered by digitalization are essential. Furthermore, similar cases can occur at any time for which orchestras have to be prepared. As a result, orchestras (and in a broader sense all kinds of organizations) need to fundamentally rethink their business models. After conducting secondary research and interviews with 10 symphony orchestra managers and 10 symphony orchestra musicians, I have identified some novel aspirations, attempts and projects selected from international and Hungarian symphonic orchestral life to provide excellent examples of how the business model can be redefined and how the expectations of the $21^{\text {st }}$-century audience can be met. These examples show that there are orchestras which have understood that responding to the changing demands of consumers and utilizing the opportunities given by technology is essential, although it is still a question of how many more "coronavirus waves" are needed to make it clear for all orchestras that fundamental changes are necessary to preserve a market-leading position or become a market leader.
\end{abstract}

Keywords: business model, symphony orchestra, digitalization

Funding: The present publication is the outcome of the project „From Talent to Young Researcher project aimed at activities supporting the research career model in higher education," identifier EFOP-3.6.3-VEKOP-16-2017-00007 co-supported by the European Union, Hungary, and the European Social Fund. 


\section{Introduction}

Regardless of the industry, in today's ever-changing world no business model is forever: it has to be tailored to the current needs, market, social and environmental conditions in order to prosper in the future as well. The importance of business model innovation is also highlighted by the current coronavirus situation: only those organizations can survive or even be the winner of the pandemic which can renew their operation. The situation both gives an opportunity to the organizations and forces them to change and fundamentally rethink their operation. The pandemic causes an extremely difficult situation for symphony orchestras, as they have to cancel their performances and redefine how to reach their audience. Orchestras which can react quickly - or can react at all - to the new circumstances will be able to survive this period and may gain competitive advantage. In the case of those which cannot tailor their operation to the present situation - and in a broader sense, to the changing needs of the $21^{\text {st }}$ century -, survival is questionable.

This study aims to identify novel aspirations and innovative projects of symphony orchestras compared to the 'traditional' orchestra model which exclusively focuses on the preservation of classical music in the physical space. I presume that these novel attempts change significantly one or more elements of the orchestras' business models and exploit the opportunities offered by digitalization.

\section{Theoretical background}

Although the first appearance of the term 'business model' dates back to the 1950s, the concept of business model became popular only around the mid-1990s, with the advent of the internet and information technologies (Zott et al., 2011; Downs \& Velamuri, 2018). Though Porter (2001) interpreted business modeling as a useless concept, several studies have pointed out its practical benefits. Nowadays, in a rapidly changing world, fast responsiveness to challenges, adaptability to changes, and the ability to dynamically renew the operation of an organization are gaining even more importance. It provides an opportunity for fast, focused, real exploration and learning with little use of resources (Horváth et al., 2018).

Business model represents the operational logic of the organization - in other words, the system of "business" ("how the organization creates, delivers and captures value," Osterwalder \& Pigneur, 2010, p. 14.) - and focuses on the way that value is created. According to these three dimensions, the authors have developed a business model canvas with nine building blocks (BMC: Business Model Canvas, see Table 1). 
Business modeling tools are not only suitable for reviewing the operation of for-profit companies. In the case of non-profit organizations, serving social goals as well, value creation has a dual focus: in addition to economic value, they also have to create social value (Weerawardena et al., 2019). Although these organizations do not focus on maximizing profits, they cannot ignore economic considerations. A business model is only viable, and an organization can only pursue its social or cultural goals if it generates more revenue than costs.

Digital transformation is fundamentally changing how organizations operate and deliver value to customers. The advancement of technology inevitably affects competition and strategies (Mészáros, 2020). According to the list of Forbes (2020), the most valuable companies have platform business models (e.g., Apple, Google, Microsoft, Amazon, Facebook). In recent decades, platforms have become the new management paradigm and have been studied widely (Csontos \& Szabó, 2018), for example in the case of (smart) cities (Csukás \& Szabó, 2019) or in connection with industry 4.0 (Szabó et al. 2019). Platforms are often considered 'network orchestrators' (Libert et al. 2014) and can facilitate value creation by providing opportunities for content producers ('creators') to present their offers to other segments (Van Alstyne, 2016, Gawer \& Cusumano, 2014, Eisenmann et al., 2011). It is important to emphasize the significance of ICT in knowledge transfer and on the job learning (Hortoványi \& Ferincz, 2015) in connection with platform business models as well: it can be an internal development barrier if some employees are unable to use the platform.

In a rapidly changing world, no business model is forever; it needs to be continuously improved in order to survive and operate successfully. Thus, in the case of symphony orchestras, it is not enough to rely on the existing repertoire and follow traditional models. One of the biggest challenges for symphony orchestras is the question of the next generation of concertgoers (Bibu et al., 2018). Concerts can only reach a narrow section of the population - as opposed to cinemas or theaters which are much more popular. According to Alexander (2015), art that no one wants to pay for cannot survive. Orchestras must therefore strive to reach and address a wider range of consumers. Without innovatively rethinking their operation and "services", orchestras will find it difficult to win against other segments of the entertainment industry (e.g., pop music concerts, cinemas) in the competition for people's leisure time (Radbourne \& Arthurs 2007). Business model innovation is therefore needed to ensure the prosperity of orchestras in the 21st century. Business model innovation means that there is a significant change in one or more elements of the organization's business model (Horváth et al. 2018). In order to successfully innovate the business model, entrepreneurial managers are needed who can drive economic growth (Hortoványi, 2012) and can "develop and play an 
altogether different game" instead of "playing the game better than the competitors" (Markides, 1997, p. 9.).

By redefining the business model and the standards of an industry, the organization can achieve a more customer-oriented approach and address potential future customers as well. Compared to the traditional orchestral operating model, such innovative solutions can be recognized both on the international scene and in Hungary. This study aims to give an overview of these novel aspirations.

\section{Methodology}

In order to answer my research question (What kind of novel aspirations and innovative projects can be identified in the case of symphony orchestras?), I have conducted primary and secondary research as well. Figure 1 summarizes the main steps of my research.

Figure 2: Methodology

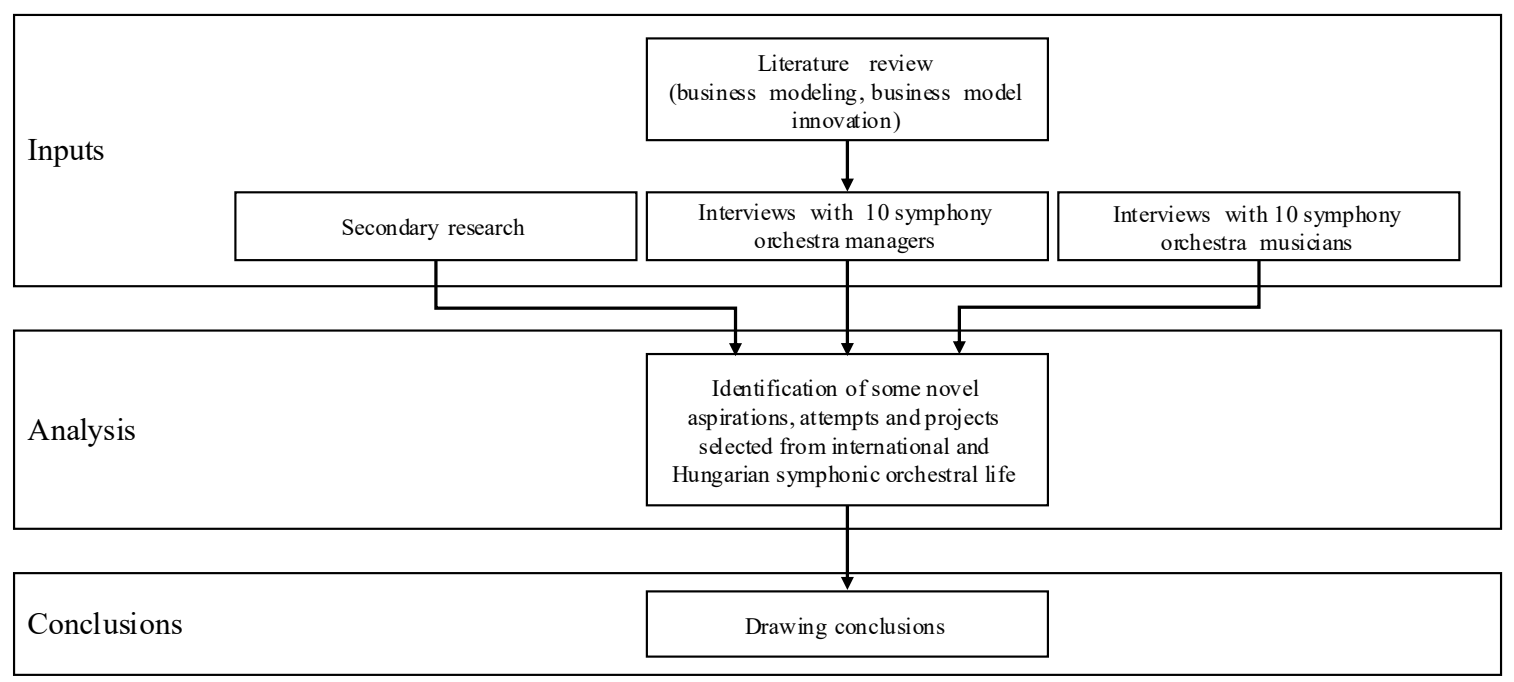

Source: own editing

In the frames of my primary research, I have conducted interviews with symphony orchestra managers and musicians. My main questions were focusing on the challenges of orchestras, the effects of COVID-19 on the symphonic orchestral life and the novel projects and ways how they are trying to reach more people - especially the youth. I was also interested in their opinions about the international scene, however, in the case of foreign orchestras, my research mainly relies on existing documents, articles. 
I have worked with semi-structured interviews: I have prepared a guideline in advance, however, during the interview I have deviated from it if it was needed, in order to go into more details on some topics. This interview technique has given me a fairly high degree of freedom and as a result - by following the recommendations of Agee (2009) - it has allowed me to identify new, unexpected, previously unexplained phenomenon by not sticking to a pre-designed set of questions. The interviews lasted 60-90 minutes, respectively. For recruiting interviewees, I have used snowball sampling (Naderifar, Goli \& Ghaljaie, 2017). I have reached the theoretical saturation point after 10 interviews both in the case of managers and musicians: new topics have no longer emerged (Constantinou et al., 2017).

Based on the interviews and the secondary research, I have identified some novel aspirations and innovative attempts which are detailed in the following section.

\section{Results}

\section{Innovative repertoire - addressing and involving new audiences}

We can often hear about the problem of the aging audience of classical music (Váradi, 2010, Figaro, 2013). In order to have a music-lover core audience in the future as well, great attention must be paid to reaching out to new segments, especially younger people, and expanding the target market. Having recognized that today's consumers, especially the younger ones, typically appreciate creative, innovative productions, many orchestras have come up with innovative repertoires and productions: they come up with a novel concept, look for unusual concert venues, or integrate different genres and branches of art into their programs (see e.g., the Cincinnati Symphonic Orchestra, the Brooklyn Philharmonic, the Dohnányi Orchestra of Budafok or the Danubia Orchestra of Óbuda).

Reaching a new audience is not only possible with an innovative repertoire. Many orchestras try to engage a wider range of consumers with unconventional concerts that adapt to the rhythm of young people's lives by breaking the conventions and leaving the formalities (see e.g., the Midnight Music concert series of the Budapest Festival Orchestra, the "Spicy Classics" series of the South Netherlands Philharmonic or the "Night/Light" concerts of the above-mentioned Cincinnati Symphony Orchestra). 


\section{Online streaming through platforms}

Digitization opens up new ways for the orchestras to rethink their value proposition and also to reach and address audiences in an unusual way. Nowadays, "digital thinking" is essential in the field of cultural management as well (Hunt, 2019). Live concert streaming is no longer a novelty; however, the Berlin Philharmonic's Digital Concert Hall project was the first initiative that used social media to broaden the audience globally by making the orchestra's concert recordings available to consumers around the world via the Internet (Digital Concert Hall, 2019). Thus, the audience can access the orchestra's recordings or even live concerts anytime, anywhere. Nowadays, almost all orchestras both international and Hungarian - make available previous concert recordings and live performances by online streaming, which is currently gaining even more importance in the pandemic situation.

According to the research of the Association of Hungarian Symphony Orchestras (2020), Hungarian orchestras have previously used the Internet to share their productions, however, no content has been created specifically for the online space. In 2020, as a result of the pandemic, it has fundamentally changed: the vast majority of orchestras have started to use social media to stay in touch with their audiences, and due to the closure of concert halls, online, live concert streaming has become a popular way to perform. Streaming typically serves a dual purpose: on the one hand, it helps to keep in touch with the audience, and on the other hand, it can also generate income, if the orchestra makes its production available in exchange for a "ticket". For online streaming, most orchestras use YouTube Live, Facebook Live, or Instagram Live which are widely known and easily accessible platforms. Although it is worth examining some further options which are more professional and give better opportunities for the monetization of the productions (e.g., Dacast used by the Royal Academy of Music or Brightcove used by the Metropolitan Opera, the Sydney Symphony Orchestra, and the San Francisco Opera). Some of these platforms are specialized for music (e.g., Stageit) and besides ensuring the conditions of streaming, they also market the performer and their show (Corton, 2020). 


\section{LOLA - a software to decrease latency and a platform to connect musicians}

Nowadays, there are many technologies and applications which make it possible to teach and play music online (e.g., Skype, Messenger, Viber, Teams, Google Meet). These are widely known, easily accessible, and free solutions that do not require any special tools. In many cases, however, latency and the poor quality of sound cause serious problems. In contrast, LOLA (low latency AV streaming system) can reduce latency to less than 30 milliseconds and as a result, it is suitable for distance musical interactions, even in the case of a very 'tempo sensitive' repertoire where timing is a critical factor (Drioli et al., 2013). Thanks to LOLA, several successful productions have taken place in recent years, even if the performers were thousands of kilometers apart (LOLA, 2021). The ease of use of the software is proven by the fact that concerts were successful even in cases when the musicians started to get to know each other and the software just one day before the concert (without any special training).

\section{Interactive productions with gamification}

As previously mentioned, one of the main problems for symphony orchestras is that they can hardly address the youth. The Australian Discovery Orchestra has responded to the challenge with an excellent idea: as part of its digital strategy, it has turned its previous recordings into "virtual experiences". The audience can listen to the piece by playing a video game: they have to solve various challenges and complete tasks in order to earn points and ,keys” which unlock the next part of the piece (Grasmayer, 2017). In another video game, the orchestra focuses on music education in a similar way, by using a virtual environment, short videos, and audio materials (ADO, 2021).

\section{Effective workflows enhanced by virtual reality}

The cooperation of two Finnish VR pioneers (Zoan and Varjo) and the Finnish National Opera and Ballet (FNOB) points out that new technologies have a raison d'être in the field of culture as well, by contributing to more efficient workflows. In the frames of the collaboration, FNOB has the chance to pre-visualize the upcoming productions without much investment. As a result, FNOB can save stage time and make the processes more effective (Teivainen, 2020). 


\section{Discussion and recommendations}

Compared to the „traditional" symphony orchestra performances, the previously detailed innovations, novel aspirations renew the value proposition: the orchestras add new elements (e.g., integrating other musical genres and branches of art, creating a multisensory experience, using unusual concert venues, and integrating gamification and interaction) and raise convenience and accessibility. By leveraging digital opportunities, orchestras can redefine the concert experience, reach audiences in a novel and perfectly convenient way, and can overcome the barriers of geographical distance: location is not restricted to concert halls anymore. By adapting to the demographical and social changes of the $21^{\text {st }}$ century, not focusing exclusively on the preservation of classical music, and eliminating the perception that symphony orchestra concerts are not suitable for everyone, these above-mentioned orchestras can address new audiences, including younger people as well.

Besides enriching the value proposition and reaching new customer segments, these orchestras also change significantly other building blocks of their business models (see Table 1 for some examples).

In accordance with Horváth et al. (2018), Csontos \& Szabó (2018), Hortoványi \& Ferincz (2015), Van Alstyne (2016), Gawer \& Cusumano (2014), Eisenmann et al. (2011) and Libert et al. (2014), my research has underpinned the importance of business model innovation and digitalization in the cultural sector as well and has highlighted how virtual reality, platforms, and other software and technologies can contribute to the successful operation of an orchestra by enabling more efficient workflows and creating added value to customers. It is important to emphasize the significance of leadership and management in this process (Morris, 2002): the best music director, the best musicians, and all the money in the world are not enough on their own, the key to success lies in the right leadership. 
Table 1: Business Model Innovation of Symphony Orchestras

\begin{tabular}{|c|c|c|}
\hline Building blocks of BMC & $\begin{array}{l}\text { Orchestras offering } \\
\text { innovative repertoire and } \\
\text { concert experience }\end{array}$ & $\begin{array}{l}\text { Orchestras exploiting the opportunities } \\
\text { offered by digitalization }\end{array}$ \\
\hline Customer segments & $\begin{array}{c}\text { The youth and fans of other } \\
\text { music genres }\end{array}$ & $\begin{array}{l}\text { Children, young people, and those who } \\
\text { would be unable to attend the } \\
\text { performance in person (due to e.g., } \\
\text { geographical distance) }\end{array}$ \\
\hline \multirow[t]{2}{*}{ Value proposition } & $\begin{array}{l}\text { Newness: integrating other } \\
\text { musical genres and branches }\end{array}$ & $\begin{array}{c}\text { Newness: integrating gamification and } \\
\text { adding interaction }\end{array}$ \\
\hline & $\begin{array}{l}\text { of art, creating a } \\
\text { multisensory experience, } \\
\text { using unusual concert venues }\end{array}$ & $\begin{array}{c}\text { Convenience and accessibility: location } \\
\text { is not restricted to concert halls } \\
\text { anymore }\end{array}$ \\
\hline Channels & $\begin{array}{c}\text { The physical space, concert } \\
\text { venues }\end{array}$ & $\begin{array}{l}\text { Platforms, social media, the webpage } \\
\text { of the orchestra }\end{array}$ \\
\hline Customer relationships & $\begin{array}{l}\text { Personal contact with the } \\
\text { audience }\end{array}$ & Automated services, co-creation \\
\hline Revenue structure & Ticket sales & Revenues from streaming \\
\hline Key activities & $\begin{array}{l}\text { Choosing and inviting guest } \\
\text { artists, rehearsals, concerts }\end{array}$ & $\begin{array}{l}\text { Online concert streaming through } \\
\text { platforms, turning the previous } \\
\text { recordings into "virtual experiences" } \\
\text { (video games), using VR for more } \\
\text { effective workflows }\end{array}$ \\
\hline Key resources & $\begin{array}{l}\text { Human and intellectual: the } \\
\text { orchestra, artists and their } \\
\text { knowledge }\end{array}$ & $\begin{array}{c}\text { Technological, human, and intellectual } \\
\text { resources: the platforms and } \\
\text { technologies and employees who can } \\
\text { use them }\end{array}$ \\
\hline Key partners & $\begin{array}{l}\text { Other orchestras, bands, and } \\
\text { representatives of other } \\
\text { branches of arts }\end{array}$ & VR companies, platform owners \\
\hline Cost structure & $\begin{array}{l}\text { Cost of inviting guest artists } \\
\text { (e.g., pop musicians, actors, } \\
\text { dancers, etc.) }\end{array}$ & $\begin{array}{l}\text { Costs of using a platform or software } \\
\text { (e.g., LOLA), recording productions, } \\
\text { and creating video games }\end{array}$ \\
\hline
\end{tabular}

Source: own editing 
Although, business model innovation and digitalization raise some further questions and challenges for orchestras: they have to balance between serving economic goals (e.g., being profitable) and social goals (e.g., creating social value). Furthermore, when innovating the value proposition and creating productions that address the audience in an unusual way, they have to preserve the traditional values of symphony orchestras as well. Digitalization also poses great difficulties: previously, the operation of orchestras relied on live performances, while currently - as a result of the pandemic - they have to focus on the online space. It requires different models and productions: the previously successful performances are not necessarily popular in the virtual space. In order to overcome these barriers and achieve long-term success, orchestras have to continuously experiment, adapt to the changing needs of their customers and handle the changes of the world.

\section{References}

ADO (2021) Australian Discovery Orchestra. https://australiandiscoveryorchestra.com

Agee, J. (2009): Developing qualitative research questions: a reflective process. International Journal of Qualitative Studies in Education, 22(4), pp. 431-447. https://doi.org/10.1080/09518390902736512.

Van Alstyne, M. W., Parker, G. G. \& Choudary, S. P. (2016): Pipelines, Platforms, and the New Rules of Strategy: Scale now trumps differentiation. Hardvard Business Review, 94(April), pp. 54-62. https://doi.org/https://hbr.org/2016/04/pipelines-platforms-andthe-new-rules-of-strategy

Alexander, V. D. (2015): Markets: Artistic and Cultural. In James D. Wright (ed.), International Encyclopedia of the Social \& Behavioral Sciences (pp. 564-568). Amsterdam: Elsevier. https://doi.org/10.1016/B978-0-08-097086-8.10410-6

Association of Hungarian Symphony Orchestras (2020): Zenekaraink on-line aktivitása. ZeneKar, 28(1), pp. 49-51.

Bibu, N., Brancu, L. \& Teohari, G. A. (2018): Managing a Symphony Orchestra in Times of Change: Behind the Curtains. Procedia - Social and Behavioral Sciences, 2 38, 507 516. https://doi.org/10.1016/j.sbspro.2018.04.030

Constantinou, C. S. - Georgiou, M. - Perdikogianni, M. (2017): A comparative method for themes saturation (CoMeTS) in qualitative interviews. Qualitative Research, 17(4), pp. $571-588$.

Corton, M. (2020): Looking for monetized platforms in a pandemic - Part 2. https://www.synchtank.com/blog/looking-to-monetized-music-platforms-in-a-pandemicpart-2/

Csontos, R. S. \& Szabó, Z. R. (2018): A versengés új színterei: platformok stratégiaimenedzsment-megközelítésből. Vezetéstudomány - Budapest Management Review, 49 (9). pp. 57-69. https://doi.org/10.14267/VEZTUD.2018.09.05

Csukás, M. \& Szabó, Z. R. (2019): Platform ambidexterity: fundamental tensions in platform strategies Conferencepaper: EURAM 2019 Conference 
Digital Concert Hall (2019) https://www.digitalconcerthall.com/en/info

Downs, J. B. \& Velamuri, V. K. (2018): Business model innovation in a knowledge revolution:

An evolutionary theory perspective. Managerial and Decision Economics, 39(5), pp. 550562. https://doi.org/10.1002/mde.2926

Drioli, C. Allocchio, C. \& Buso, N. (2013): Networked Performances and Natural Interaction via LOLA: Low Latency High Quality A/V Streaming System. In: Nesi P., Santucci R.

(eds.): Information Technologies for Performing Arts, Media Access, and Entertainment.

ECLAP 2013. Lecture Notes in Computer Science, 7990. pp. 240-250.

https://doi.org/10.1007/978-3-642-40050-6_21

Eisenmann, T., Parker, G., \& Van Alstyne, M. (2011). Platform envelopment. Strategic

Management Journal, 32(12), pp. 1270-1285. https://doi.org/10.1002/smj.935

Figaro (2013): Kihalóban a komolyzene közönsége? [Is dying out the audience of classical music?] http://figaro.reblog.hu/uresen-konganak-az-operahazak

Forbes (2020): The 2020 World's Most Valuable Brands. https://www.forbes.com/the-worldsmost-valuable-brands/\#27af0694119c

Gawer, A. \& Cusumano, M. A. (2014): Industry platforms and ecosystem innovation. Journal of Product Innovation Management, 31(3), pp. 417-433.

https://doi.org/10.1111/jpim.12105

Grasmayer, B. (2017): Four innovations in classical music https://www.musicxtechxfuture.com/2017/05/22/four-innovations-in-classical-music/

Horváth, D., Móricz, P. \& Szabó Z. R. (2018): Üzletimodell-innováció [Business Model Innovation]. Vezetéstudomány, 49(6), pp. 2-12. https://doi.org/10.14267/VEZTUD.2018.06.01

Hortoványi, L. (2012): Entrepreneurial Management. Budapest: AULA

Hortoványi, L. \& Ferincz, A. (2015): The impact of ICT on learning on-the-job. The Learning Organization 22(1), pp. 2-13. https://doi.org/10.1108/TLO-06-2014-0032

Hunt, N. (2019): How TSO and its new music director plan to attract younger audiences and revitalize classical music in Canada. August 31. CBC News.

https://www.cbc.ca/news/entertainment/tso-gustavo-gimeno-revitalizing-classical-music1.5253601

Libert, B., Wind, Y. \& Beck, M. (2014). What Airbnb, Uber, and Alibaba Have in Common. https://hbr.org/2014/11/what-airbnb-uber-and-alibaba-have-in-common

LOLA (2021) https://lola.conts.it/

Markides, C. (1997): Strategic Innovation. Sloan Management Review, 38(5), pp.9-23.

Mészáros, T. (2020): A stratégiaalkotás változásának mozgatórugói, fejlődési trendjei a XXI. században. Köz-gazdaság, 15(1), pp. 30-42. https:/doi.org/10.14267/RETP2020.01.04

Morris, T. W. (2002): Symphony Orchestra Boards and Board Leadership. Harmony: Forum of the Symphony Orchestra Institute, 14, pp. 47-52.

Naderifar, M., Goli, H. \& Ghaljaie, F. (2017): Snowball Sampling: A Purposeful Method of Sampling in Qualitative Research. Strides in Development of Medical Education, 14(3), pp. 1-6. https://doi.org/10.5812/sdme.67670 
Osterwalder, A. \& Pigneur, Y. (2010) Business Model Generation: A Handbook for Visionaries, Game Changers, and Challengers. Chichster: Wiley

Porter M. E. (2001): Strategy and the Internet. Harvard Business Review, 79(3), 62-78. Retrieved from https://www.gospi.fr/IMG/pdf/strategy-and-the-internetporter-hbr2001.pdf

Radbourne, J. \& Arthurs, A. (2007): Adapting musicology for commercial outcomes. In Radbourne, J. \& Arthurs, A. (ed.): Proceedings Valencia Spain - 9th International Conference on Arts and Cultural Management (AIMAC 2007) CD A1-4, pp. 1-13. Valencia, Spain.

Szabó, Z. R., Horváth, D. \& Hortoványi, L. (2019): Hálózati tanulás az ipar 4.0 korában. Közgazdasági szemle, 66(1), pp. 72-94. http://dx.doi.org/10.18414/KSZ .2019.1.72

Teivainen, A. (2020): Finnish VR pioneers put heads together to re-imagine performing arts. https://www.goodnewsfinland.com/finnish-vr-pioneers-put-heads-together-to-re-imagineperforming-arts /

Váradi, J. (2010): Hogyan neveljünk értő közönséget a komolyzenének? [How to educate an audience to acquire a taste for classical music?] PhD Dissertation, University of Jyväskylä.

Weerawardena, J., Salunkeb, S., Haighc, N., \& Mort, G. S. (2019): Business model innovation in social purpose organizations: Conceptualizing dual social-economic value creation. Journal of Business Research, in press. https://doi.org/10.1016/j.jbusres.2019.10.016

Zott, C., Amit, R. \& Massa, L. (2011): The business model: recent development and future research. Journal of Management, 37(4), pp. 1019-1042.

https://doi.org/10.1177/0149206311406265 

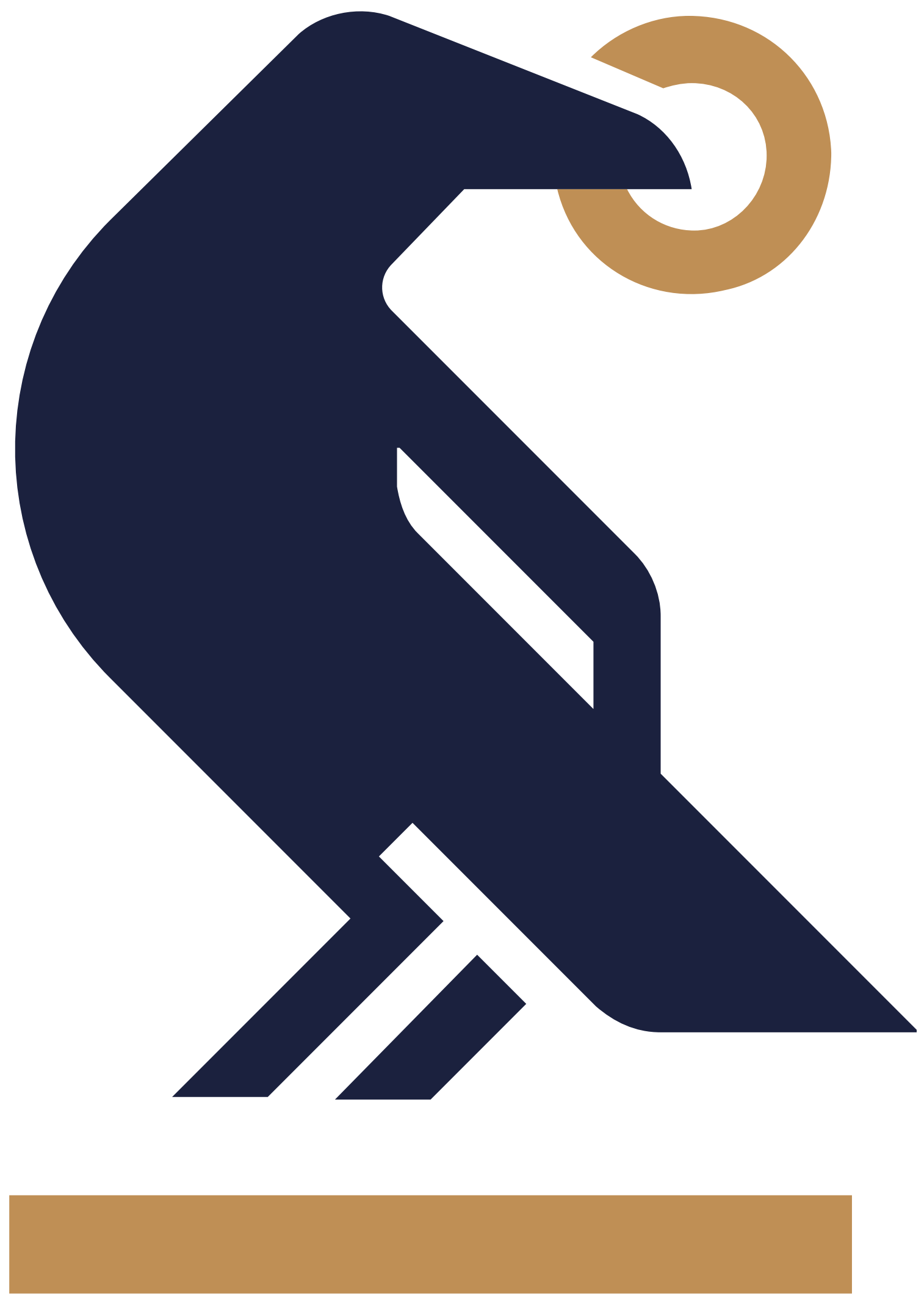